\title{
I Used to Speak in Tongues: Spirituality and Pentecostal Deconversion Narratives
}

by

Andrew Connolly

A thesis submitted to the Faculty of Graduate and Postdoctoral Affairs in partial fulfillment of the requirements for the degree of

Doctor of Philosophy

in

English Language and Literature

Carleton University

Ottawa, Ontario

(C) 2015, Andrew Connolly 


\begin{abstract}
This dissertation examines Pentecostal deconversion narratives in memoirs by Kim Barnes and Dennis Covington, in novels and short stories by Lee Smith, and in promotional interviews with Katy Perry and Megan Fox. They feature protagonists who grow out of Pentecostalism. In most cases, they are young girls who are raised in Pentecostal homes and leave their homes and religions at the same time. In place of Pentecostalism, the protagonists adopt a spirituality that is either liberal or neoliberal. Liberal spirituality encourages experimentation and assimilation of various religious practices and beliefs as long as they complement classic liberal values like individualism, freedom, rationality, pluralism, etc. Neoliberal spirituality is very similar, but it redefines the classic liberal values with a market sensibility so that freedom becomes freedom in the market, and rationality becomes self-interested rationality based on cost/benefit analysis. In most cases, these protagonists' spiritualties fall somewhere on a continuum between liberal and neoliberal extremes. The narratives privilege these spiritualties as more modern, more empowering, and more in keeping with contemporary American values. They also help position the authors as people who are educated, modern, and liberal in their approach to religion. By contrast, the conservative theology and ecstatic religious practices of Pentecostals are represented as oppressive, narrow minded, dogmatic, and most of all, irrational. By extension, Pentecostals themselves are underdeveloped, uneducated, and anachronistic. In fact, while conservative Protestants as a whole occupy an "othered" position in relation to both liberal and neoliberal spirituality, Pentecostalism becomes the epitome of "bad religion" because it embraces ecstatic experiences.
\end{abstract}


These narratives serve three compatible purposes: 1) they promote and celebrate liberal and neoliberal approaches to religion; 2) they help establish and solidify a religious/spiritual identity for the author, and by extension, membership within a religious/spiritual community (although it is an amorphous, undefined community); and 3) they provide access to a large "spiritual but not religious" audience, which embraces consumerism. To accomplish all three of these aims, the narratives use Pentecostalism and Pentecostals as a foil, a caricatured other onto which they project exaggerated negative traits. 


\section{Acknowledgements}

I would like to thank Dr. Franny Nudelman for her supervision of this project. She was enthusiastic and encouraging throughout. She challenged me in productive ways that dramatically improved the final product. I am also grateful to Dr. Travis DeCook for his guidance and his quick, helpful feedback. I also appreciate the positive reinforcement of Dr. Robert Holton. I also wish to thank Dr. Matthew Hedstrom and Dr. James Opp for agreeing to act as external examiners and making the time to participate in the defence. I would also like to thank Dr. Grant Williams, Dr. Brian Johnson, Dr. Paul Keen, Dr. Pius Adesanmi, and Dr. Percy Walton for their professional advice and encouragement throughout this process.

I am indebted to Dr. Franny Nudelman, Dr. Travis DeCook, Dr. Grant Williams, Dr, Paul Keen, and Dr. Percy Walton for employing me as a research assistant on various projects. I am also indebted to the Carleton University Graduate Students' Association and Mike's Place for employing me as a trivia host and as a softball commissioner, providing me with additional income. I owe a large debt of gratitude to Dr. Grant Williams, Margaret Haines, Neil Wilson, and the rest of the Carleton Creative Writing Camps board of directors for hiring me as a camp director, providing me with income I needed to finish my degree and invaluable experience.

I am especially thankful to my colleagues Chris Vanderwees and Chris Doody. Not only did they both read through every page of my dissertation and provide valuable feedback, they have both spent countless hours listening to me talk about my research and my academic career. They have provided helpful solutions, and more importantly, 
entertaining diversions when I needed them. I am also thankful to Chris Johnson for being the final proof-reader of this project.

This dissertation would not be possible without my partner Chelsea Houde. She read through portions of my dissertation and offered important suggestions. She patiently listened to me at my most anxious, my most frustrated, and my most irritated.

Meanwhile, she has endured my stress and my mess. Throughout it all, she has given me more than I could have imagined.

I dedicate this dissertation to David and Rebecca Connolly, my parents, who have been my strongest supporters throughout my academic career. 


\section{Table of Contents}

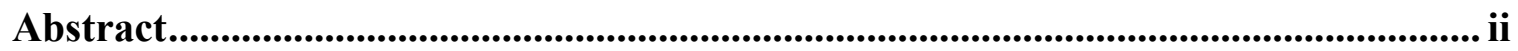

Acknowledgements ........................................................................................................................ iv

Table of Contents ...................................................................................................... vi

Introduction ............................................................................................................................ 1

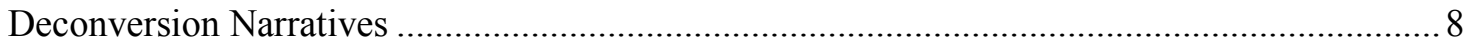

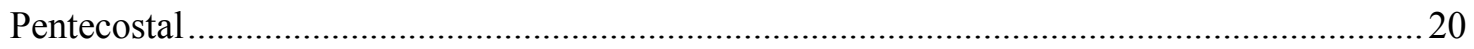

Liberal and Neoliberal Pentecostal Deconversion Narratives ................................................26

\section{Chapter One}

\section{Winning America: Neoliberal Spirituality and the Legacy of}

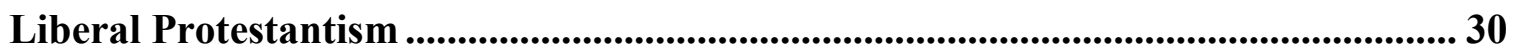

The "Wins" and "Losses" of Liberal Protestantism ...................................................................

Conservative Protestants and "Bad" Religion ........................................................................... 36

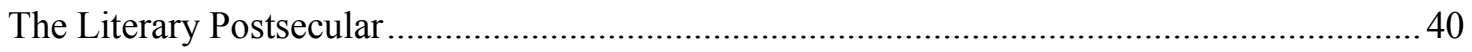

Neo-Liberal Spirituality and the "New Age" ....................................................................... 48

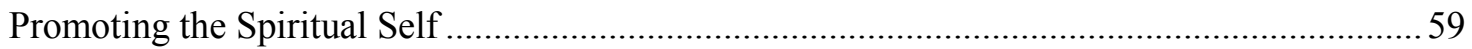

Conclusion: Markets, Audiences, and Neoliberal Community ....................................................65

\section{Chapter Two}

\section{Put Away Childish Things: Kim Barnes and the Coming-of-Age Deconversion}

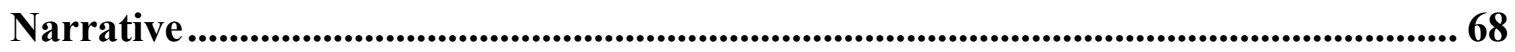

Coming-of-Age Deconversion Narratives ........................................................................ 70

The Full Spectrum of Feminine Colour.................................................................................. 80

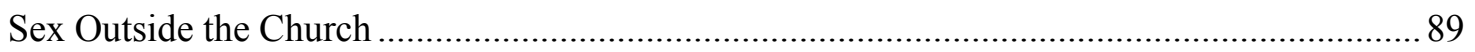

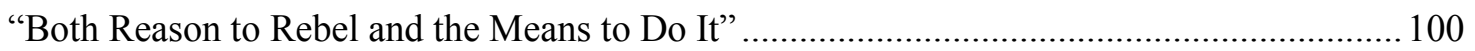


Conclusion.

\section{Chapter Three}

She May Be Hot, but She is Also Really Crazy:

Celebrity Pentecostal Deconversion Narratives .................................................... 115

Spiritual Competence and Celebrity Studies ….............................................................. 117

From Angel Eggs to Worshiping the Hamburgler: Katy Perry's Deconversion Narrative ..... 124

Her Whole Body Filled with Electric Current: Megan Fox’s Deconversion Narrative ........... 133

Conclusion: Literary Celebrities and Author-Commodities ................................................ 143

\section{Chapter Four}

\section{In But Not Of: The Conversion and Deconversion of a Reporter}

in Covington's Salvation on Sand Mountain ................................................................. 146

"He Was Also a Friend": Participant-Observers in Appalachia ............................................ 150

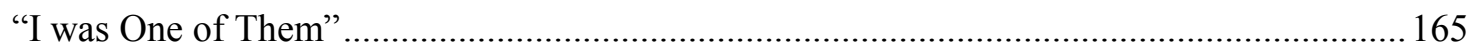

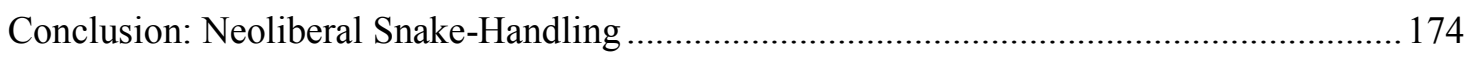

\section{Chapter Five}

\section{Not Real Good at Modern Life: Appalachian Pentecostals}

in the Works of Lee Smith............................................................................... 177

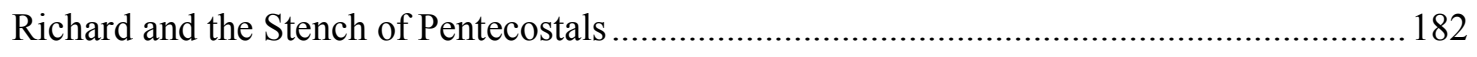

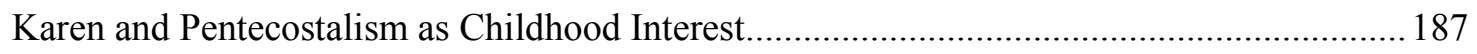

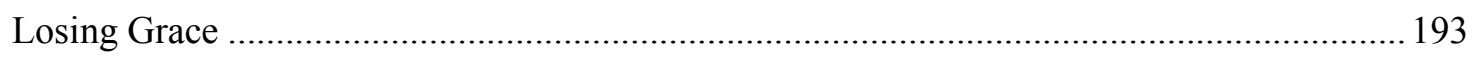

I Could Have Been Her............................................................................................... 210

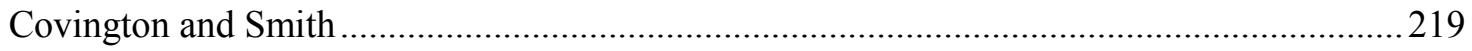

\section{Conclusion}

The Potential of Pentecostal Deconversion Narratives............................................. 223 
The Gains and Losses of Deconversion.

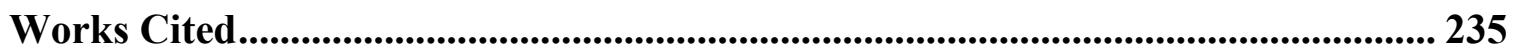




\section{Introduction}

In the mid-1990s, Sherri Reynolds was a struggling writer. She had received an MFA in Creative Writing from Virginia Commonwealth University, where she studied with Lee Smith and Paule Marshall (Charters 56). Reynolds even had a critically acclaimed first novel published with Putnam. This, however, did not turn into financial success. "I was in the worst financial state of my life," she says in an interview with Mallay Charters, "I was living on credit cards" (55). She shared an apartment with fellow writer Amy Tooter, who was in an equally precarious position financially. During the winter, the apartment "was so cold she had to wear a hat to bed" (Walzer E1). Despite her financial hardship, she was optimistic about her new novel. "My main character was a mortician, and I studied mortuary science and visited funeral homes, and then I put together this enormous novel and submitted it to my agent" she says on her personal website ("Book Notes"). Her agent, unfortunately, was not as optimistic. Reynolds says her agent told her she had

written an embalming manual, not a novel. She said nothing happened in my book, and my characters were "gratuitously ugly," and that I should stick it in a box and bury it. She also said something along these lines: "You're a southern girl. You know all about tobacco farming and religion. Why don't you write a book about that?" (“Book Notes”)

Reynolds says she was "really angry with my agent" but "if she wanted a 'southern' story, if she wanted to know about growing up around tobacco farms and fundamentalist Christianity, then that's what she'd get!" ("Book Notes"). The result was The Rapture of Canaan. 
In The Rapture of Canaan, Ninah grows up in an isolated Pentecostal community led by her authoritarian grandfather, Herman. Herman has rules for everything, and he is solely responsible for deciding what punishments to dole out when those rules are broken. Punishments include sleeping in an open grave, water torture, and expulsion. As Ninah grows up, however, she begins to see flaws in Herman's theology. She also starts to notice that others see those flaws as well. The combination leads her to question her own beliefs, and eventually turn away from her faith in her grandfather's Pentecostalism. Meanwhile, Ninah also enters puberty and, unequipped to understand her own longings for a boy in the compound, ends up pregnant. Though Ninah has lost faith, she lies and covers up the truth in order to remain in the community. In particular, she claims that her baby was immaculately conceived. This claim induces a battle of wills with her grandfather. The resolution comes only after her grandfather has a stroke, which renders him incapable of leading the community. The novel ends with a hopeful uncertainty for the community as well as for Ninah and her baby.

Reynolds says The Rapture of Canaan was "a desperation book," (qtd. in Charters 56) which she wrote with an "urgent, righteous fury" in less than six weeks ("Book Notes"). The fury resulted from more than just her agent; Reynolds says that novel was, in part, a way for her to process her "religious confusion" ("Book Notes"). She was raised in a strict Pentecostal home, and as she grew up she began to turn away from that Pentecostalism. She says that "like Ninah, [she] often felt misunderstood, like an outcast even in [her] own family" ("Book Notes"). Reynolds decries what she calls the "fearrhetoric" of her Pentecostal past in both her interviews, and perhaps more subtly, in her fiction ("Book Notes"). Elsewhere she explains "I wanted to tackle the hypocrisy and 
cruelty of this kind of Christianity - the blind acceptance of a doctrine that keeps an individual from having to think for herself or question the world she's part of" (qtd. in Shoup and Denman 268). She hopes that, by couching her objections in fiction, she will reach some people who fall prey to that rhetoric, especially members of her own family: "What I really wanted was for my sister to keep my niece from growing up with the same kind of fear" ("Book Notes"). To do this, she portrays Pentecostalism as antiquated, especially when subtly compared to an unnamed, pluralistic spirituality that floats in the background of the novel. To accentuate this portrayal, Reynolds amplifies the Pentecostalism of her childhood with medieval rules and punishments (Reynolds Rapture 319); none of the more salacious rules and punishments, she admits, were part of the community she actually left.

Of course, all of these ambitions that Reynolds describes worked together towards her goal: to write a novel that her agent and publisher could sell. She did not, however, achieve this goal at first. After a short time, Putnam decided to remainder the novel because of poor sales; The Rapture of Canaan ended up in bargain bins across the United States (Walzer E1). In fact, the publisher was so disappointed in the performance of the novel that it sent Reynolds a severance letter, cancelling the third book of her three-book contract. Meanwhile, Reynolds's job teaching creative writing at William and Mary College was being cut due to a budget crunch (Carroll). These circumstances caused Reynolds to question her career choices: "It made it seem like maybe I was on the wrong path. I thought maybe my writing was not supposed to be for anyone but me. I was beginning to prepare to resee things completely" (qtd. in Carroll). That is when Reynolds 
got a call from Oprah. Oprah told her that The Rapture of Canaan was going to be the Oprah Book Club selection for May 1997.

The Rapture of Canaan is what publishers refer to as an "Oprah-type novel" (Max 36). In the midst of the Oprah Book Club heyday, Oprah herself said she was drawn to novels that feature "voices of young girls, women in struggle, who ultimately have to triumph" (qtd. in Lofton 163). The first author selected to be part of the club, Jacquelyn Mitchard, expands on this definition: "it's often about a woman who, through her own wits and grit, pulls herself out of difficult circumstances" (qtd. in Rooney 3). As Eva Illouz points out, this "type" of novel "amplified and resonated with many of [Oprah's] existing themes and narrative formats, especially the theme of suffering biographies" (103). Suffering biographies, the Oprah-type novels, and even the act of reading itself becomes part of Oprah's broader project, which Kathryn Lofton calls "a mass spiritual revolution" (3). Oprah's message is "that you are responsible for your own life ... to get people to take charge" (qtd. in Clemetson 44). For Oprah, taking charge means making decisions based on a neoliberal standard, decisions that are rational, self-interested, and made to improve one's sense of self-worth with minimal investment, especially when those decisions involve what (not whether) to buy and consume. Oprah's message is so quintessentially neoliberal that Janice Peck has called her "a cultural icon for the neoliberal era" (1). Oprah uses a neoliberal standard to evaluate everything, including literature, shampoo, and even religion. In terms of religion, Lofton argues that Winfrey celebrates religion that does not "do anything to disrupt the primacy of democracy and the cult of capitalism;" the ideal religious believer "does not allow religion to interfere with her consumption," consumption which is linked to self-improvement (49). Oprah, of 
course, does not use the term "religion." As Lofton explains, "for [Oprah], religion implies control and oppression and the inability to catalog shop" (49). Oprah frequently draws on her own Evangelical past to typify this kind of "religion." By contrast, Oprah's "spirituality [is] the nondogmatic dogma that encourages an ambiguous theism alongside an exuberant consumerism" (49). The particularity of an individual's religious beliefs and practices, whether they are rooted in a single tradition or an eclectic hybrid of multiple traditions, are essentially "accessories ... as long as you can spend, feel good about yourself, and look good" (50). The Rapture of Canaan is an Oprah-type novel because it fits the proper narrative format, with a female character who endures difficult trauma, but also because it demonstrates an Oprah-like approach to religion by critiquing a brand of Christianity that appears at odds with Oprah's larger project. In her appearance on Oprah's television show, Reynolds describes Ninah's journey as one of self-realization in which it is Ninah's act of "taking charge" that allows her to be free of the Pentecostal community. Reynolds glosses over the importance of circumstances like Herman's stroke and Ninah's uncertain relationship to the community at the end of the novel. In fact, Reynolds emphasizes the novel's alignment with Oprah's broader project, sometimes at the expense of oversimplifying the novel, in order to gain access to Oprah's audience of potential readers and book consumers.

The rewards of that access were immediately apparent. The Rapture of Canaan rapidly scaled bestseller lists around the country and Putnam scrambled to print more and meet the demand. Jan Karon's similarly titled novel Out of Canaan also suddenly appeared on bestseller lists, and most booksellers attributed this to readers who mistook

\footnotetext{
${ }^{1}$ Lofton notes that after 9/11, Oprah also makes a distinction between Muslims and "modern Muslims" to the same effect (49).
} 
Karon's book for Reynolds's book ("Oprah Shuts"). The increased attention caused the publisher to have a change of heart. It bid over 500 thousand dollars on Reynolds's third novel, a novel it could have had for 30 thousand before it cancelled the contract it had with her (Charters 56; Carroll). William and Mary College revised their budget in order to offer Reynolds her position back. Reynolds says she had "fun" turning them both down. She signed with Harmony Books and took a teaching position at Old Dominion University instead (Carroll). Her newfound financial security allowed her to pay off her debt, and buy a house and fill it with furniture (Walzer). It also gave her the luxury of taking her time to write her next novel. "I decided to take a break from writing and being in public," she says in a 2001 interview. "I've dedicated the last few years to other things, to taking walks and paddling my little boat around" (qtd. in Shoup and Denman 275). Reynolds calls herself an introvert, and she says the amount of publicity that went along with being an Oprah Book Club author was overwhelming. By the time she published her fourth novel five years later, she was a little more prepared. "What I'm doing right now is business," she tells an interviewer shortly after the Oprah show. "There's nothing in my personality that wants to be sitting here with you ... But if I don't do this part, I won't have the option to do the other, the writing" (qtd. in Carrol). Immediately after saying this, she positions herself as someone who is spiritual but not religious, someone who has an educated, liberal, pluralistic, spirituality which she contrasts with the Pentecostalism of her childhood. This positioning is part of publicizing her novel and gaining access to a spiritual, neoliberal audience.

This dissertation examines Pentecostal deconversion narratives like the one Reynolds writes in The Rapture of Canaan. They appear in memoirs, novels, short 
stories, and even in promotional interviews where celebrities tell their own stories. None of them have the same kind of "fairy-tale" publication history that The Rapture of Canaan has, but they do share many of the same qualities. They all feature protagonists who grow out of Pentecostalism. In most cases, they are young girls who are raised in Pentecostal homes and leave their homes and religions at the same time. In place of Pentecostalism, the protagonists adopt a spirituality that is either liberal or neoliberal. Liberal spirituality encourages experimentation and assimilation of various religious practices and beliefs as long as they complement classic liberal values like individualism, freedom, rationality, pluralism, etc. Neoliberal spirituality is very similar, but it redefines the classic liberal values with a market sensibility so that freedom becomes freedom in the market, and rationality becomes self-interested rationality based on cost/benefit analysis. In most cases, these protagonists' spiritualties fall somewhere on a continuum between liberal and neoliberal extremes. The narratives privilege these spiritualties as more modern, more empowering, and more in keeping with contemporary liberal American values. They also help position the authors as people who are educated, modern, and liberal in their approach to religion. By contrast, the conservative theology and ecstatic religious practices of Pentecostals are represented as oppressive, narrow minded, dogmatic, and most of all, irrational in both the liberal and neoliberal sense. By extension, Pentecostals themselves are underdeveloped, uneducated, and anachronistic. In fact, while conservative Protestants as a whole occupy an "othered" position in relation to both liberal and neoliberal spirituality, Pentecostalism becomes the epitome of "bad religion" because it embraces ecstatic experiences which appear as irrational and a site of manipulation. 
While the primary focus of this dissertation will be on narratives published in monograph form, it is not the only form in which the narratives appear. Both celebrities and authors themselves use adapted versions of these narratives in promotional interviews. In the case of authors, their promotional interviews work in conjunction with their novels or memoirs to present a cohesive approach to religion, much like how Reynolds's interview with Oprah works together with her novel. As a result, these narratives serve three compatible purposes: 1) they promote and celebrate liberal and neoliberal approaches to religion; 2) they help establish and solidify a religious/spiritual identity for the author, and, by extension, membership within a religious/spiritual community (although it is an amorphous, undefined community); and 3) they provide access to a large "spiritual but not religious" audience, which embraces consumerism. To accomplish all three of these aims, the narratives use Pentecostalism and Pentecostals as a foil, a caricatured other onto which they project exaggerated negative traits. Though the narratives combine elements of different genres, including coming-of-age stories, the primary form is that of deconversion narratives.

\section{Deconversion Narratives}

Deconversion narratives tell the story of an individual's transition from part of a religious tradition or community to being no longer part of that tradition or religious community; from insider to outsider. Most scholarly work on the topic examines the experience of deconversion from a sociological or anthropological perspective, with little or no attention to narrative. For example, work by David Bromely and Heinz Streib largely attempts to group deconversion experiences into categories. John Barbour, on the 
other hand, focusses on literary deconversion stories as written narratives. In Versions of Deconversion, he examines written works from Augustine's Confessions (which he argues is both a deconversion and a conversion narrative) to "cult" escape biographies from the 1970s. Although his larger aim is to show how the genre develops through different time periods and through different cultural contexts, he does present some defining characteristics of the genre, which are foundational to this project. First, Barbour argues that "every conversion narrative is a deconversion, and every deconversion a conversion. The 'turning from' and 'turning to' are alternative perspectives on the same process of personal metamorphosis, stressing either the rejected past of the old self or the present convictions of the reborn self" (3). In other words, there is a kind of continuum between conversion and deconversion narratives, and placement on the continuum depends on what the narrative emphasizes: the old life, left behind, or the new life. Barbour goes on to argue that, even in narratives that focus almost exclusively on the life left behind, with no mention of the new life at all, "basic convictions inevitably emerge in the analysis of mistaken beliefs" (5). These convictions come to the surface in "the standard by which a religious faith is judged to be wrong" (5); it is the "central convictions [of a narrative] that shape a perspective on the past" (5). For example, though Ninah does not end up in a clearly neoliberal spirituality at the end of The Rapture of Canaan, her reasons for rejecting Pentecostalism come from a neoliberal standard for evaluating religion. Like conversion narratives, every deconversion narrative becomes a narrative of contrasting the new life to the old, even if the new life is almost absent on the surface of the text. 
Second, despite the emphasis on contrast, Barbour also argues that deconversion narratives "rarely entail [a] total reversal" (3). There are always elements of the old life that remain intact in the new life. For example, a protagonist in a deconversion narrative may retain certain moral or ideological perspectives from her former religious life, while rejecting others. The result is a kind of paradox between the desire for a clean break with a past and the tendency to adapt, recuperate, or reimagine elements of the past to fit with the present. Joanna Brooks argues that this tension is a prominent feature of religion in the United States, and argues that critics must look for "continuities across radical discontinuities" to fully understand the way religion has developed (447). For Brooks, this approach is appropriate for both studies of broader trends ${ }^{2}$ as well as studies of specific texts that involve religion. Barbour would seem to concur. Not only does he argue that there is some continuity between the old life and the new in deconversion narratives, he argues that the continuity is often evident in the form of the deconversion narratives themselves: "the religion that is rejected deeply influences both the way the story is told and the author's present commitments" (211). In specifically Christian deconversion narratives, which are the primary focus of both Barbour's book and this project, "narratives of lost faith mirror conversion stories. Accounts of deconversion often use the same old wineskins for the new wine of unbelief' (4). In other words, both in form and content, deconversion narratives reinterpret and reappropriate elements of the old life. Studying how the narratives do this becomes a practice of finding continuities across discontinuities: authors modify and revise beliefs, practices, and conventions of

\footnotetext{
${ }^{2}$ For example, Brooks argues that "It is easy enough to detect strong continuities across the radical discontinuities from New England Great-Awakening Congregationalism through the Restoration movements of the American frontier into the Holiness and Pentecostal movements" (447).
} 
conversion narratives, simultaneously showing a continuous relationship between the old life and new life, while highlighting and emphasizing the contrast between the two.

Finally, Barbour argues that deconversion narratives can serve "various rhetorical purposes in relation to an audience," and that these rhetorical purposes are, in part, evident in the formal adaptations of conversion narratives (6). While Barbour does argue that one of the rhetorical purposes of a deconversion narrative is to "justify" the decision to leave a former faith (2), he does not fully explore the other rhetorical functions of deconversion narratives. Instead, he focusses on the tension between continuity and discontinuity, along with what he presents as an evolution of deconversion narratives through various historical time periods. Despite this, his suggestion that deconversion narratives perform multiple rhetorical functions, rather than simply accurately representing the experience of a loss of faith, along with the link he presents between deconversion narratives and conversion narratives, opens up interesting opportunities to study the rhetorical functions of deconversion narratives. By pairing Barbour with scholars who study the rhetorical functions of conversion narratives, this study will examine how these narratives repeat and adapt not only the form of conversion narratives, but also the rhetorical functions. In particular, this study will examine the way deconversion narratives help establish and define a new religious identity for individuals, and the way they help establish membership in a new community.

First and foremost, conversion narratives constitute a new identity for the protagonist of the narrative. The change, argues John E. Smith, is not slight, but rather a "change of person as if a new being now dwelt where another had lived before ... The change is so radical and so completely alters the being of the person that we are inclined 
to speak of a 'new' person being involved" (Smith 55; also see Foucault, Hermeneutics 214). Dana Anderson builds on Smith's interpretation, arguing that conversion narratives portray "transformations of an individual's very sense of who or what he or she is" (16). Both scholars point to the biblical conversion story of Paul (formerly Saul) as an illustration of this concept of conversion. Saul is so utterly changed on the road to Damascus that he changes his name. Paul reinforces this notion when he writes "Therefore if any man be in Christ, he is a new creature: old things are passed away; behold all things become new" (KJV, 2 Corinthians 5:17). The conversion narrative, then, becomes the narrative of passing from the old to the new, and the new becomes apparent in contrast to the old. For example, where Saul was intent on persecuting new Christians, Paul becomes a leader in the early church. Of course, conversions are not always so dramatic. As Wayne C. Booth notes, many contemporary Evangelical conversion narratives feature subjects who are raised in a particular religious community and their "conversion" is simply a stronger commitment to the ideals of that community. As a result, these narratives either accentuate the difference between life before and after the greater commitment, or emphasize a fall from grace which takes place just before the greater commitment. The latter results in narratives which "are almost always closely parallel in structure to the story of humanity as a whole: the heroes are born in the Homeland, lost their way in the Badland, and are now restored [in the Homeland]" (372). Booth uses a spatial metaphor to illustrate the way these stories contrast two identities: the narratives contrast the old, "Badland" identity with the new, or at least renewed, "Homeland" identity. This characterization of conversion narratives accurately describes typical Evangelical conversion narratives, which regularly feature a dramatic change of 
identity and result in an equally dramatic contrast between the old and new.

Deconversion narratives continue this practice by accentuating the difference between the old, insider identity and the new, outsider identity. In other words, even when the two identities seem very similar, the emphasis is always on the difference that privileges the new, outsider identity.

The contrast is not simply represented in the narrative events, but also in the narrative voice. In other words, there is not only a contrast in the narrative itself between the old life/identity and the new, but also a contrast in the way the narrator describes the old life and the way the participants in the old life understand it. To describe this phenomenon, critics tend to rely on the example of Augustine. As William Spengemann explains, in Confessions "Augustine, who has already received the gift of faith stands upon the fixed point of an immutable truth and looks back, or rather down, upon the sinful life he led between his birth and his conversion" (1; also see Poland; Booth 387; Poewe 195). This is what Anderson describes as "postconversion hindsight" (69). It manifests itself in two ways: in the narrative organization of events and in the language used to describe the old life. Karla Poewe argues that "Augustine, like charismatics today, place events, encounters, and appointments so that they reveal God's plan for the individual" (198). In other words, conversion narratives tend to organize the events of the old life so that they clearly setup the conversion experience; the old life becomes a clear precursor to the conversion experience and the new life. This creates what Wayne C. Booth describes as a dramatic irony, where "tellers and listeners in a sense dwell in the Homeland looking down upon the wandering characters, hoping they will finally make it Home, but also enjoying the spectacle of their mistakes and sins" (373). In this narrative 
construction, the old life is full of problems like wandering, mistakes, and sin, setting up conversion as the answer to those problems, and the new life as relatively problem free. The old life is incomplete, whereas the new life is complete. By association, the old identity is also incomplete, whereas the new one is complete. Furthermore, throughout the mistakes and sin of the old life, the narrator finds traces of God leading him or her to conversion. Deconversion stories use the same kind of narrative construction. The events and experiences of the old, insider life constitute a set of problems that leaving the old religion solves, at least to some degree. Though divine providence is rarely a factor in deconversion narratives, there often remains a sense that the protagonist is propelled toward leaving the old life.

The language the narrator uses to describe the old life reinforces this postconversion hindsight. Susan Harding argues that, in many ways, conversion is "a process of acquiring a specific religious language" (34; also see Erzen 995). It is not simply accepting a particular understanding of the world, along with associated practices and rituals, but also a language that works with the beliefs and practices. For Evangelicals, this language often has a clear Biblical tone. Drawing on her anthropological research, Anna Meigs similarly argues that Evangelicals use Biblical language, metaphors, and topologies to "show how God's words have operated dynamically in [their lives], shaping [their] very notion of self and the meaning of events that have happened to [them]" (91). The way narrators describe their old lives, both in terms of the way they order events and the language they use to describe the events, and themselves, illustrate a contrast between the new life and the old. In some cases, narrators overtly state the difference, pointing out that they used to understand their situation one 
way, but now understand it in a very different, and better way. Just as often, however, this privileging of the new perspective is much more subtly contained in the vocabulary the narratives use. For Barbour, this is precisely how deconversion narratives show the "convictions" of the new life, even when the narratives do not specifically outline those convictions. For example, when Reynolds describes the Pentecostal theology of her childhood as "fear-rhetoric" which limits or coerces an individual, it reveals more about her current religious ideology than it does about Pentecostal theology ("Book Notes"). In other words, analyzing the way deconversion narratives portray the old, insider life reveals some of the constitutive elements of the new, outsider life.

This postconversion hindsight of the narrator sometimes bleeds into the perspective of the protagonist in the context of the old life; protagonists often demonstrate elements of the new life, identity, and perspective even before they convert. Specifically, the narratives have a tendency to present the protagonist as somehow incomplete or out of place in the old life. This adds to the dramatic irony that Booth notes in Evangelical conversion narratives and what Meigs identifies as the effort to present one's life as part of a divine plan. The new life becomes a full realization of the identity the subject always had, the one that God intended. The contrast between the old life and new life in this case is not one of two different identities, but one of an incomplete identity and a fully realized identity. Similarly, deconversion narratives also present protagonists as somehow out of place inside the religion they eventually leave. Leaving, then, becomes the way these protagonists fully realize an identity they have always had. In some cases, this sets up a further contrast: one between the protagonist in the old life and those around the protagonist. While the protagonist is out of place and destined for 
the new life, those around her are content and settled in the old life, thus unlikely to convert (or deconvert). This is the situation Reynolds describes, when she says that "like Ninah, [she] often felt misunderstood, like an outcast even in [her] own [Pentecostal] family" ("Book Notes"). In other cases, however, representation of the old identity as simply incomplete opens up the possibility that audience members in the old life might still be able to make the transition to the new life; they too might be able to realize their full, true identity. In either case, it undermines the notion of conversion or deconversion being a radical identity change. The result is that many conversion and deconversion narratives contain competing notions of identity: on one hand, identity is unstable and subject to change (i.e. old identity and new identity), and on the other hand, identity remains stable and can only be incomplete or fully realized. Despite the inconsistency, both perspectives on identity work together to present a particular notion of what it means to be someone in the new life. Both perspectives move in and out of prominence depending on which is more rhetorically useful in the particular context.

Conversion narratives also help secure membership in a religious community. Patricia Caldwell argues that this was the primary purpose of testimonies in early puritan New England. She identifies three major standards for these testimonies: “(1) relation before the entire congregation of (2) a genuine experience of conversion (not doctrinal 'knowledge' or 'belief'), which (3) was required of all who would join the church" (45). This provided an opportunity for an "elect church ... [to] 'test' the inward spiritual estates of all its members" (45; also see Watkins 29). In order to pass this test, potential members needed to tell their conversion stories in their own words. This was, explains Caldwell, part of a larger "Reformation impulse to eliminate mindless ceremony" (54). 
Instead of repeating what English separatist John Greenwood called "certayne words taught them by rote ... [which] a parrot might be taught to say" (qtd. in Caldwell 54), potential members were required to demonstrate the sincerity and genuineness of their conversion by relating their experience in a personal but public way. As Caldwell notes throughout her book, The Puritan Conversion Narrative, the practice was not without its controversy, and did not achieve a universal formal procedure; there were many variations in the number and type of public testimonies that a new member were to perform. There is even less information on what criteria church members and leaders used to judge the sincerity and genuineness of these testimonies. Still, if Susan Harding is accurate in her suggestion that conversion is adopting a particular religious vocabulary, and the implied theologies and practices connected to the vocabulary (34), then new members would have to balance the need to demonstrate that they had internalized that vocabulary without appearing to reproduce exact phrases and terminology which could be memorized; they would need to demonstrate fluency in a religious language without appearing to be a parrot.

This tension is evident in contemporary studies of Evangelical churches. It is rare among Evangelical, especially Pentecostal, churches that potential members must deliver a conversion narrative that the church body then evaluates before individuals officially gain membership in the community. Instead, conversion narratives in this context secure a more unofficial, social membership in a particular church community. This comes partly through establishing fluency in a particular religious vocabulary and commitment to the theological principles and practices connected to it. In his mid 1960s study of Christian Evangelicalism, Daniel Stevick suggests that "a way of talking, a way of acting, 
a body of predictable responses, have grown up within fundamentalism, and conformity with these is the criterion for acceptance ... A quite specific group of catchphrases mark a Fundamentalist" (56). More anthropological studies confirm Stevick's findings. For example, Meigs notes that, in the religious community she studied, "the repetition of standardized phrases such as 'I've been blessed,' 'Christ the Lord of my Life,' 'my Christian walk,' ... [etc] signal[s] to the listeners that this is not colloquial conversation ... but a very special variety of religious talk, one by which speakers indicate their membership in a particular community" (94; also see Barnhart 70; Boone 83). These catchphrases often privilege particular theological concepts, and that privileging becomes the basis for group membership. For example, Andrew Singleton argues that, "in privileging certain community preferred meanings about speaking in tongues, the narrator is able to position her or himself within the community of tongues speakers" (363). Narrators perform this privileging by using a specific vocabulary to describe their experiences of conversion and glossolalia (speaking in tongues). The privileging can also extend to political positions, as Tanya Erzen notes, where "testimonies reinterpret individuals' past lives in the language of sin and salvation in the light of their new evangelical Christian identity" (996). When these past lives involve queer sexualities or criminal activity, argues Erzen, it can support political aims of conservative Evangelicals, and secure membership in a community of conservative Evangelicals for those delivering the testimonies.

Members learn this language, and the associated practices, theological principles, and political positions, in part by listening to the testimonies of others. As Elaine Lawless points out, "converts ... learn appropriate ways to tell their own conversion stories by 
listening to other conversion stories" (12-13). Delivering an appropriate testimony, therefore, becomes a kind of mimicry, or as Meigs describes it, "quoting" (88; also see Harding 12). Yet, quoting is not, on its own, enough. Just as early Puritan converts were required to deliver their testimonies in their own words, balancing the "personal" and the "public," contemporary Evangelicals must also demonstrate that their conversion has been genuine in some way that goes beyond repeating particular phrases. On a formal level, this often means interspersing the catch phrases throughout a testimony that is largely delivered in the everyday speech of the convert. More than that, however, Meigs argues that a "testimony proves itself, has validity and authority if it is performed with emotional depth" (98). Unofficial acceptance into a religious community is, therefore, gained when a convert describes his or her conversion experience using the right phrases, signaling particular theological and political beliefs, accompanied by the right amount of emotional depth. This has important implications for deconversion narratives as we shall see later.

These rhetorical functions are all mobilized in deconversion narratives as well. Deconversion narratives, especially the ones I study in this project, work to establish identities for narrators, protagonists, and authors, identities that are set in opposition to the religious identities they leave behind. The narratives I study in this project work to establish a spiritual, identity in opposition to a Pentecostal one. Just as often, the narratives attempt to establish membership in a new community, both by demonstrating that the protagonists have adopted new insider language, and by modifying the qualifications of insiders in the new community. In the case of Pentecostal deconversion narratives, this can mean advocating a detached appreciation for ecstatic experiences like 
speaking in tongues from a neoliberal perspective. Establishing membership is particularly problematic, as we shall see, for narratives that position liberal or neoliberal spirituality as the new life because they lack the institutional hierarchy and stability of Evangelicalism. Nonetheless, the narratives I study attempt to appeal to spiritual communities and readerships, primarily in the way they depict Pentecostals.

\section{Pentecostal}

The origins of the Pentecostal movement are not entirely clear. The popularly accepted narrative is that, in early 20th century Kansas, Charles Parham developed a theology regarding baptism of the Holy Spirit, and the ecstatic religious experiences which followed that baptism, most centrally glossolalia. Parham founded a ministry in Houston, where he not only preached this theology, but welcomed African-Americans to join his multiracial congregation. African-American William Seymour attended the meetings, and took the theology and practice to Los Angeles, where he held the celebrated Azusa street revivals (1906-15). People from various denominations, and various ethnic and racial backgrounds attended these revivals. The narrative suggests that Pentecostalism spread across the United States, and ultimately across the world as a result of these revival meetings. Many scholars have disputed this narrative, arguing instead that Pentecostalism arose as a result of multiple revival meetings throughout the world (Kay 17), however, Azusa Street holds a special place within Pentecostalism as the assumed origin point. Although the original participants in the revival came from various denominations, many denominations rejected the ecstatic experiences promoted at these revivals, as well as the theology behind them that Parham developed. The result is that, 
gradually, churches that adopted both the ecstatic experiences and Parham's theology began to form associations, which ultimately led to several different Pentecostal denominations. Through the course of the 20th century these denominations have multiplied, with numerous theological variations and political allegiances (see Burgess). Despite this diversity, Harding notes that Pentecostals tend to be lumped together with Evangelicals (76).

Two other religious movements have a very close relationship with Pentecostalism. The first is the Holiness movement, which predates Pentecostalism. The Holiness movement, which came out of Methodism in the mid-19th century, emphasizes the "sanctification" of believers. ${ }^{3}$ Like Methodists churches, Holiness churches also featured ecstatic religious experiences, including glossolalia. Many of the first participants in the Azusa Street revival came from Holiness churches, and brought back the greater emphasis on ecstatic experiences as well as Parham's theology. This caused a divide within many churches and Holiness associations. While some embraced Pentecostalism, others rejected it entirely. The result is that, in some cases, there is a clear divide between Holiness and Pentecostal churches, while in other cases the labels are used simultaneously or interchangeably.

The second movement is the charismatic movement, which began in the late 50s and gained momentum in the $60 \mathrm{~s}$. In this movement the ecstatic religious experiences commonly associated with Pentecostalism, especially glossolalia, were exported to various denominations. Unlike the Azusa Street revivals, many denominations found ways to accommodate these experiences, largely because those involved with the

\footnotetext{
${ }^{3}$ The term "sanctified" comes from the theology John Wesley. As Arthur Paris explains, sanctification "purified the believer of inward sin, giving him 'perfect love' toward God and man" (16).
} 
movement deemphasized the connection between the experiences and Parham's theology. This allowed denominations to interpret the experiences in ways that supported their existing theologies. In some cases, the movement led to interdenominational, or nondenominational churches, which deemphasized theological differences. The majority of these churches, however, remain within the Evangelical fold. As a result, these churches often have much more in common with Pentecostal churches than other mainline Protestant churches, and even some fundamentalist churches. More importantly, the deconversion narratives on which this dissertation focusses tend to represent Charismatic, Holiness, and Pentecostal churches in much the same way: the churches all emphasize ecstatic religious experience, they all fit within the Evangelical moniker, and they are all politically and theologically conservative. While this focus hardly represents the full diversity of these three movements, it is less a selective omission on the part of the dissertation, and more an indication of the absence of deconversion narratives that represent other kinds of Pentecostal, Holiness, and Charismatic churches. As we shall see, the focus on conservative Pentecostals serves particular rhetorical aims in relation to liberal and neoliberal "spiritual" audiences.

Since Pentecostalism falls under the umbrella of Evangelicalism, the stereotypes surrounding Pentecostals often overlap with those associated with Evangelicals. These stereotypes date back to the 19th century with prominent examples in episodes of Mark Twain's Adventures of Huckleberry Finn and Johnson Jones Hooper's Adventures of Captain Simon Suggs. George Hovis notes that these satirical portrayals of Evangelicalism "as simply backwoods barbarism ... revival preachers as con men and congregations as gullible hypocrites" become the foundation for later stereotypes 
surrounding Evangelicals generally, and Pentecostals specifically (624-25). Pentecostals present what Hovis calls "the easiest most vivid target" for emphasizing these traits in Evangelicals. The ecstatic religious experiences common in Pentecostal churches (and often rejected by other Evangelical denominations) are emotional, appear non-rational, and are often presented as evidence of vulnerability and, by extension, the site of manipulation; these experiences become evidence that Evangelicals in general, and Pentecostals in particular, are regressive and out of place in the contemporary, modern world. H. L. Mencken provides one of the most lucid examples of this. As part of his coverage of the Scopes trial, ${ }^{4}$ he writes about a "Holy Roller" revival meeting in the mountains of Rhea County. The article is filled with descriptions that emphasize the fact that the congregation is rural and lower class. The meeting comes to a climax as a preacher "[throws] back his head and [begins] to speak in tongues—blub-blub-blub, gurgle-gurgle-gurgle. His voice [rises] to a higher register. The climax [is] a shrill, inarticulate squawk, like that of a man throttled" (580). Mencken goes on to describe other members of the congregation "squirming and jabbering," having "convulsions that [begin] at the shoulders and end at the hips," praying with "a delirious caterwauling, like that of a tomcat on a petting party," and flinging their "great bulk on the ground and [jabbering] an unintelligible prayer" (580-81). Despite the "barbaric grotesquerie" Mencken is quick to add that this is not "a comic scene" because "the poor half-wits [are] too horribly in earnest" (580). While he begins the article by distinguishing these mountain "Holy Rollers" from Northern Liberal Protestants, and even some Baptists, by the end of the article he warns that "such is the existence among fundamentalists ... what

\footnotetext{
${ }^{4}$ In 1925, high school teacher John Scopes was arrested for teaching evolution in school. The subsequent trial gained national attention as a lightning rod for debates surrounding culture, religion, and science.
} 
the great heritage of mankind comes to in regions where the Bible is the beginning and the end of wisdom, and the mountebank [William Jennings] Bryan . . . is pointed out to sucklings as the greatest man since Abraham" (582). The ecstatic experiences of Pentecostals become the clear evidence that those who support the creationist side of the Scopes trial are "poor half-wits" engaged in "barbaric grotesquerie" and "inarticulate ... jabbering."

This representation of ecstatic religious experiences is still evident more than 80 years later in Jesus Camp, a 2006 American documentary film directed by Rachel Grady and Heidi Ewing. The documentary was widely reviewed and was nominated for an Academy Award. More importantly, it illustrates that the stereotypes that Mencken used during the Scopes trial are still active and circulating in contemporary America. The film focuses on a Pentecostal children's summer camp run by Pastor Becky Fischer, where children are taught a mixture of Pentecostal theology and conservative politics. Interspersed are clips of radio talk show host, Mike Papantonio, speaking about the Christian Right political movement, and Evangelicals in general. After several scenes with ominous music in which children at the camp speak in tongues, cry, and pray, all while affirming conservative political positions, the film climaxes in a conversation between Fischer and Papantonio. While Fischer asserts that she is helping children learn about God, Papantonio counters by saying:

The word learn is different than indoctrinate. God gave us a brain. God gave us the freedom to choose, and learning is part of that choice, and I think every time the fundamentalist movement, Becky, interferes with that we're doing harm. We're doing harm to the progression of mankind ... 
you can tell a child anything ... you can make a child into a soldier that carries an AK47... how do we ignore that we are all of a sudden creating children soldiers for the Republican party. . . It's a witch's brew. It's going to take over democracy.

Fischer's replies, or at least the way they are presented in the choppy section of the film, offer little to counter Papantonio's critique. At one point she says "you can call it brainwashing, but I am radical and passionate in teaching about their responsibility as Christians, as God fearing people, as Americans.” Though Fischer is not claiming to brainwash the children, she is the one who appears to introduce the term, linking her camp to brainwashing. Rather than Mencken's half-wits, the congregation here is full of equally, if not more vulnerable children. These children are being brainwashed into a war against democracy, taking away their God-given ability to make their own autonomous choices by someone whom the film presented as poorly educated, since she needs to be told the definitions of the words she is using. ${ }^{5}$ The ecstatic religious experiences in the film are simply the means by which this brainwashing takes place. They are the site where emotions overflow and are manipulated toward a nefarious political end.

While the deconversion narratives in this dissertation all address the Pentecostal stereotype, they do not all address it in the same way. There are some, of course, that evoke the stereotype in order to secure their position within a spiritual community. In doing so, however, they reject Pentecostalism, along with Evangelical theology and ecstatic religious experiences. Many of the narratives attempt to separate the ecstatic experiences and some elements of Pentecostal theology from the "half-wit" conservative

\footnotetext{
${ }^{5}$ Chapter One expands on the particular political context of the film, namely, the rise of the religious right and the election of George W. Bush.
} 
"barbaric grotesquerie" they have come to represent; these narratives attempt to reinterpret the experiences, which can regain their purity once separated from the pollution of conservative manipulation in the Pentecostal communities. One of the focuses of this dissertation is on the ways in which the narratives accomplish, or fail to accomplish these goals while positioning authors, narrators, and protagonists as spiritual.

\section{Liberal and Neoliberal Pentecostal Deconversion Narratives}

The spiritualties that the deconversion narratives in this dissertation study embrace, whether they be liberal or neoliberal, are heirs of liberal Protestantism. Recent scholarship on liberal Protestantism and its apparent demise in the 1960s suggests that traces of liberal Protestant ideas about religion, broader values, and pluralism are present in dominant cultural approaches to religion in the United States. Some even point to the kind of religion that Oprah promotes as one of the heirs to liberal Protestant ideas and values. Since Oprah's spirituality is quintessentially neoliberal, this creates an interesting genealogy for neoliberal spirituality. In Chapter One, then, I argue that neoliberal spirituality builds upon and accentuates particular aspects of liberal Protestantism and liberal spirituality. This link presents more than just a genealogy. It also helps to highlight limitations with the kind of pluralism that liberal Protestantism, liberal spirituality, and neoliberal spirituality promote—limitations that ultimately undermine the individualism and autonomy it celebrates.

In order to privilege these kinds of spirituality over Pentecostalism, many deconversion narratives in this dissertation employ a coming-of-age structure. Not only does this narrative structure tap into an audience that is familiar with coming-of-age 
memoirs and novels, it also presents an opportunity to privilege one ideology or religion over another in a subtle way; in this case, neoliberal spirituality over Pentecostalism. While these coming-of-age narratives represent Pentecostalism as having some positive attributes, the attributes are underdeveloped. By contrast, liberal and neoliberal spirituality fosters these supposedly positive attributes and helps them develop. As a result, Pentecostalism is represented as antiquated and stifling, while neoliberal spirituality is portrayed as modern and liberating. In Chapter Two, I explore this narrative structure using Kim Barnes's two memoirs In the Wilderness: Coming of Age in an Unknown Country and Hungry for the World. Barnes has received some recognition for her work, earning a Pulitzer Prize Nomination for In the Wilderness. The success of her memoirs helped her to secure a tenured teaching position at the University of Idaho. Beyond this recognition, however, Barnes provides interesting examples for study because of how sympathetically she portrays her Pentecostal parents. Perhaps more than any other author referenced in this study, Barnes makes great efforts to bridge the rifts between herself and her neoliberal spirituality that arise after she leaves home and Pentecostalism behind. Her efforts, however, come off flat and condescending next to the critique of Pentecostalism contained in the memoirs.

Deconversion narratives, including those that double as coming-of-age stories, extend beyond literary fiction and memoirs. They often appear in various popular culture forms, including interviews with celebrities. Chapter Three analyzes the ways in which two contemporary celebrities deploy their deconversion narrative in promotional interviews to gain and maintain access to different kinds of audiences. Pop singer Katy Perry uses a coming-of-age deconversion narrative that presents her emergence from the 
confines of Pentecostalism as a neoliberal triumph over difficulties and traumas to achieve a successful life. Movie star Megan Fox, however, presents a deconversion narrative that has a muddled timeline and is steeped in a sensual nostalgia. In this chapter, I argue that both approaches are calculated moves to appeal to different audiences. Both cases, however, draw on the caricatures of Pentecostals and privilege neoliberal spirituality.

While Pentecostal stereotypes tend to be repeated regardless of the different cultural contexts in which Pentecostals live, the context can sometimes add an extra layer of significance to those stereotypes. This is particularly true for Appalachian Pentecostals. This group of Pentecostals is unique because they practice snake handling and, as a result, they have received a disproportionate amount of coverage in popular media as well as in scholarly studies. Chapter Four introduces the Appalachian community and examines a deconversion narrative that may seem out of place with the others in this dissertation. Not only is Dennis Covington the only male author/storyteller in this study, but calling his deconversion narrative in Salvation on Sand Mountain a coming-of-age story is also a stretch. Covington enters the community as a reporter and slowly, over the next few years, becomes deeply involved in their rituals. He even contemplates joining them permanently. Ultimately, however, he decides to leave the community. Some scholars have critiqued the way Covington depicts his departure, but in this chapter I argue that the depiction of his departure is not the only problematic portrayal in his memoir. Instead, I posit that Covington sets up a dichotomy throughout the memoir, a dichotomy that privileges the neoliberal spirituality he adopts at the end over the Pentecostalism he dabbles in throughout the narrative. 
While scholars critique Covington for his portrayals of Appalachian Pentecostals, they celebrate novelist Lee Smith. In Chapter Five, I argue that this celebration is unwarranted, and instead I suggest that, in her fiction, Smith participates in the same tradition of condescending portrayal as Covington. Ultimately, her fiction works to critique Pentecostalism while celebrating neoliberal spirituality. Her promotional interviews enhance this privileging. In them, she downplays the nuance in the fiction itself and positions herself alongside the readers as a neoliberal observer of backwards, constraining, and ultimately anachronistic religious practices.

The tendency of deconversion narratives in this study to draw on stereotypes and other Pentecostals does not fully realize the potential of deconversion narratives. There is an opportunity to create and explore alternative spiritualties that embrace the supernatural and ecstatic religious experiences while representing a loss of faith without stereotyping and othering Pentecostals. This dissertation's conclusion sets out to recover this possibility, which is left unrealized in all of the narratives in this study, while at the same times suggesting ways to expand this scholarship. In the end, I turn to articles by Michelle Syba as an example of a deconversion narrative that does not resort to stereotypes and othering. Instead, it depicts Pentecostals with a sensitive respect. Even though Syba does not explore or experiment with the spiritual or supernatural in her new, more secular worldview, her narrative disrupts Pentecostal stereotypes rather than support them. 


\section{Chapter One: Winning America: Neoliberal Spirituality and the Legacy of Liberal Protestantism}

The legacy of liberal Protestantism has become a hot topic among scholars of religion in the past five years. A New York Times article from July 2013 proclaims that "a growing cadre of historians of religion are reconsidering the legacy of those faded establishment Methodists, Presbyterians and Episcopalians, tracing their enduring influence on the movements for human rights and racial justice, the growing 'spiritual but not religious' demographic and even the shaded moral realism of Barack Obama-a liberal Protestant par excellence" (Schuessler). The article then goes on to mention several scholars who have published monographs on the topic, including David Hollinger, Leigh Eric Schmidt, Matthew Hedstrom, and Elesha J. Coffman. With the exception of Coffman, each of these scholars draws on a 1995 paper by sociologist N. J. Demerath. In that paper, published in the Journal for the Scientific Study of Religion, Demerath argues that "the liberal values central to American culture" owe their dominance to liberal Protestantism (460). These values, he posits, include "individualism, freedom, pluralism, tolerance, democracy, and intellectual inquiry" (Demerath 460). He then goes even further to suggest that church attendance, donations, and affiliation declined precisely because young liberal Protestants internalized these values. This leads Demerath to argue that "liberal Protestants have lost structurally at the micro level because they won culturally at the macro level" (463). Hollinger paraphrases this rather clunky sentence; he writes that liberal Protestants "lost American Protestantism . . . but they won the United States" (45). 
What this "win" means is that the liberal values and approaches to religion are not the property of an identifiable religious community, but rather they are accepted as natural and normal by a wide range of individuals. These individuals are free to research, explore, and experiment with a variety of religious practices and belief systems, drawing on those that seem to suit them best for as long as those practices and beliefs seem beneficial. Any combination is acceptable as long as it does not threaten the guiding liberal values. This exploration is tied to the marketplace, both in terms of the way individuals make decisions, and in terms of the way individuals explore and experiment through the purchase of goods and services, especially books. Members of this group do not use a label to self-identify, but rather they subtly display and deploy a particular understanding of religion that conforms to liberal values. This chapter examines this group as an heir to liberal Protestant values and understandings of religion. It begins by focusing on the decline of liberal Protestant institutions, and then moves on to examine the way the liberal Protestant legacy is carried on in literature and the literary marketplace. Ultimately, this chapter argues that neoliberal spirituality is the contemporary heir of liberal Protestantism, and that this spirituality permeates the literary marketplace.

\section{The "Wins" and "Losses" of Liberal Protestantism}

Hollinger is perhaps the most controversial of the recent scholars who develop Demerath's thesis. In an article first published in 2011, and later expanded in a 2013 monograph, he focuses on the National Council of Churches, which before 1950 was the Federal Council of Churches. It is an association of liberal Protestant denominations. 
Hollinger examines positions issued by the organization as well as articles and books published by leaders associated with the group. What he finds is that, in the latter half of the twentieth century, liberal Protestant leaders wanted to demystify Christianity by deemphasizing theology, expunging belief in the supernatural, and critiquing institutional religion. They engaged in a kind of self-critique. Hollinger argues that these leaders wanted to promote liberal values through political activism. In other words, liberal Protestant leaders attempted to rechannel devotion to the supernatural into enthusiasm for progressive political projects like the Civil Rights movement, gay rights, women's liberation, and perhaps most notably, the anti-war movement in the 1960s and 1970s. Hollinger acknowledges that many lay people in liberal Protestant churches did not readily accept this shift, and they opted instead to migrate to more conservative, evangelical churches. But Hollinger also notes that those who did accept the shift, those who internalized the values that liberal Protestant leaders were promoting, began to see the institution of church as less and less important. Liberal Protestant leaders encouraged a priesthood of all believers in which participants experimented with various religious traditions in order to find commonalities. Ultimately, it was up to individuals to make decisions about what they wanted to believe and practice, so long as it adhered to liberal values. As Hollinger suggests, liberal Protestant churches "facilitated [a] greater exposure to a diverse world" and "encouraged [people] to explore it" (38). As a result, participants began to think that "Christianity was not so indispensable to the advancement of the values [that liberal Protestant leaders] most energetically taught to them" (44). According 
to Hollinger, these individuals, most of them younger, left liberal Protestantism precisely because they had accepted its message and saw better vehicles to promote that message. ${ }^{6}$ Hedstrom provides more details about how this message was disseminated to lay people, though for an earlier time period. He examines several reading programs organized by liberal Protestants, including the Religious Book Week in the 1920s, the Religious Book Club, founded in 1927, and the Religious Books Round Table of the American Library Association. These programs were promoted from the pulpit in liberal Protestant churches, and they provided resource lists for independent book clubs and libraries around the country. Hedstrom's argument is that the books promoted through these programs demonstrate a slow dissemination of the liberal values like individualism, freedom, pluralism, and intellectual inquiry. For example, he traces the development of religious pluralism from the beginning of these programs, in which part of the aim was to avoid "sectarian propaganda," until the late 1940s, during which books by popular Jewish and Catholic mystics were included on the list. Even books by liberal Protestant authors emphasized "spiritual forms emerging from and moving beyond liberal Protestantism" (7). As Hedstrom shows, the seeds of the religious experimentation that Hollinger examines were already in place, namely, openness to a greater variety of religious practices, including Eastern religions. Hedstrom explains, "a large majority of Americans remained Christian, but many no longer saw appropriating practices and insights from other traditions of faith as a threat to their own integrity and identity" (223).

\footnotetext{
${ }^{6}$ Scholars have developed several different terms to describe this personalized religion composed of a variety of elements from different religions, including "religious bricolage" (Luckmann 136), "religion a la carte" (Bibby 82), "pastiche spirituality" (Schmidt 2), and "Sheilaism” (Bellah et al. 221).
} 
This appropriation was rooted in a religious approach to reading and consuming books. Rufus Jones, one of the early founders of the liberal Protestant reading programs, advocated a religious approach to reading. Individuals were to read carefully and meticulously, preferably with "pencil in hand, to mark cardinal passages, to make notes, and to digest the message which the book contributes" (Jones, qtd. in Hedstrom 12). In other words, while the content of the books reveal the gradual development and expansion of most liberal values, the approach to reading points to the promotion of an individual religious inquiry made using books. This method of reading appears to have taken hold. Hedstrom points out that the large majority of books selected throughout these programs became bestsellers, helping to create a market for what he calls middlebrow spirituality, and this market, he argues, continued after the programs themselves ended.

This market points to another aspect of the liberal Protestantism legacy that Hedstrom identifies in his book: "a greater entanglement of religious practice with the patterns of consumerism" (Hedstrom 7). Part of Jones's plan for developing book programs for liberal Protestants was also to develop a liberal Protestant publishing industry. His strategy was to promote these books as having a "fresh and vivifying light" which "no Christian man or woman today can afford to miss" (Jones, qtd. in Hedstrom 12). These books were not evangelizing materials, nor were they books that would better explain portions of the Bible, as many books from the established Evangelical publishing industry do. Instead, they held a personal benefit that could only be realized when someone purchased and owned the book. As a demand for these books developed, more books could be produced, thus growing the industry. "What emerged," argues Hedstrom, 
"was a religious culture more strongly than ever dependent on the marketplace, especially the marketplace for books" (219). Hedstrom argues that this market for a steady stream of books that deliver a new and vivifying light has its roots in liberal Protestantism. In fact, Hedstrom goes so far as to argue that in order to understand the religion "beyond the churches" that Hollinger describes, we must understand the marketplace that liberal Protestantism helped to create.

These recent examinations of liberal Protestantism have already received some criticism. As I mentioned earlier, Hollinger's work has been very controversial. Historian Andre Hartman contends that liberal Protestants simply did not have the broad influence that Hollinger claims. Hartman argues that it is "more plausible to argue that [liberal Protestants] were caught up in a new zeitgeist that they had little to do with." To be fair, Hollinger does provide caveats in his work. He admits that the "cultural victory of [liberal] Protestants is easily exaggerated," partially because, as Hartman points out, the commitment to the liberal values that Demerath outlines was not "peculiar to [liberal] Protestants," and also because politically conservative evangelical Protestants wield so much power in the U.S. (46-47). Demerath is even more pronounced in his qualification of the liberal Protestant cultural victory. As a sociologist, he readily acknowledges the perception that "sociologists frequently use history as a tissue on which to sneeze their theories" (463). In an attempt to avoid this tendency, Demerath suggests that liberal values developed in a dialogical fashion from the very beginning in the United States. Liberal Protestant leaders and theologians adapted liberal thought from secular or other religious sources for a Christian context, and these adaptations in turn influenced thought 
in secular and other religious spheres ${ }^{7}$. While these qualifications do temper claims about the liberal Protestant legacy in the broader American context, one area on which both scholars remain agreed is how liberal Protestantism influenced the way Americans think about religion. Hollinger points to a 2009 study by Christian Smith and Patricia Snell, which finds that most American young adults, regardless of their religious affiliation, talk "like classical liberal Protestants ... paraphrasing passages from classical liberal Protestant theologians, of whom they have no doubt never heard" (qtd in Hollinger 47). They prioritize individualism, autonomy, tolerance, and intellectual inquiry over doctrinal specifics. Furthermore, they continue to define themselves against conservative Protestants.

\section{Conservative Protestants and "Bad" Religion}

While Hollinger, Hedstrom, and Demerath all celebrate the liberal Protestant legacy, Robert Orsi is critical of how it impacts the dominant view of religious pluralism in the United States, including the academy. Orsi suggests that the pluralism drawn from

\footnotetext{
${ }^{7}$ Scholars have also found that an increasing number of Jewish people in the United States combine elements of other traditions. Jack Werthheimer has even used the term "Judaism a la carte" ("Judiaism"; also see $A$ People Divided). Stephen Cohen and Arnold Eisen attribute this trend partially to the influence of liberal Protestantism, arguing that "American Jews may be moving toward Protestant constructionsindividualist, moralist, universalist - of religious identity ... [while] American Protestants may be moving toward Jewish notions of God" (190). Hedstrom examines one instance of the liberal Protestant influence on Judaism when he examines Joshua Liebman's Peace of Mind. Hedstrom argues that the book exhibits "a deep debt to the very American tradition of pragmatic and transcendental spirituality, foundational components of American liberalism" especially in its "appropriation of Emerson and [William] James" (192). In spite of this influence, Judaism "a la carte" is not exactly the same as liberal Protestantism or its direct heirs. Unlike the religion a la carte that Bibby describes, in which individuals create customized religions for themselves, Werthheimer describes a religious marketplace in which various Jewish communities offer prepackaged combinations. Cohen and Eisen go further, directly contrasting what they find among Jewish-Americans with "Sheilaism." Specifically, they argue that there is a stronger commitment to the Jewish community among American Jews, including those that draw from other traditions. Rather than eschew the "Jewish" label and the history that it entails, they hold to it. This is a direct contrast to Sheilaism, where community is suspect and commitment to a past, especially a Christian past, is tenuous, if not rejected entirely (Cohen and Eisen 39-40).
} 
liberal Protestant sources is a limited pluralism; it admits only those religions that seem to share liberal Protestant ideals. As a result, these ideals become the criteria by which a religion is judged to be "good" or "bad." Orsi argues this kind of judgment is pervasive in American universities, particularly in religious studies departments. It manifests itself in two principle ways. First, academics have a tendency to reduce other religions to liberal Protestant ideals. They present a "rationalized and sanitized" (189) version of these religions that ignores difference, especially uncomfortable difference, in pursuit of an unspoken universal essence of religion. The second way a liberal Protestant bias manifests itself in the academy is through the condemnation of "bad" religion. Orsi suggests that academics tend to reject forms of religion that appear overly emotional, irrational, regressive, or a threat to democracy. These religions "are relegated to the world of sects, cults, fundamentalisms ... primitive religion ... [etc.]" (188).

It is no surprise that the primary example of bad religion in traditional liberal Protestantism, and thus the primary other against which liberal Protestantism defined itself, is conservative Protestantism. As Hollinger, Hedstrom, and others argue, conservative Protestants, grouped together under the term "fundamentalists," biggest threat to liberal Protestantism because they shared the Protestant label while competing for political power in the U.S. Those historians outline the way that liberal Protestant ideals are consistently set in contrast to "fundamentalism." Harding suggests

\footnotetext{
${ }^{8}$ Susan Harding distinguishes between the smaller group within conservative Protestantism that selfidentified as "Fundamentalists" and the larger groups of conservative Protestants who are stereotyped using the term "fundamentalists." Self-identified Fundamentalists take a particularly militantly antimodernist stance toward the outside world. Not all conservative Protestants in the first half of the twentieth century took this stance, and many groups, including Evangelicals, were much more moderate, causing division within conservative Protestantism. Despite these differences, Harding says that "outsiders, especially liberal Protestants, academics, and journalists, [tend to] call all those who believe that the supernatural claims of the Bible are true "Fundamentalists"” (xv-xvi, 61).
} 
that in the nineteenth and early twentieth century, these stereotypes were part of an ongoing battle between conservative and liberal Protestants in which "both tried to stigmatize their opponents as marginal, the infiltrator, the upstart, the violator of order and all that was truly Christian" (64). As mentioned earlier, Harding, George Hovis, and several other scholars of American religion suggest that a shift occurred during the Scopes trial in 1925. On one hand, the journalistic portrayals of fundamentalists during the trial, especially those by H. L. Mencken, brought the stereotypical portrayals to their "apex" (Hovis 625), and "progressively homogenized, stigmatized, and appropriated the voice" of conservative Protestants (Harding 68; also see Larson 225-46). On the other hand, the "cultural judgment" that came out of the Scopes trial affirmed these portrayals as "national common sense" (Harding 63). "Fundamentalism" became "backward ... ignorant $\ldots$ rural $\ldots$ anti-intellectual . . superstitious . . duped . . bigoted . . dogmatic ... absolutist ... authoritarian ... a rigid, homogenous, thing stuck in the past" (Harding 62). It became solidified as the "bad" religion that liberal Protestants defined themselves against: overly emotional, irrational, regressive, a threat to democracy (Orsi 188). Portrayals of conservative Protestants, from retellings of the Scopes trial like Stanley Kramer's 1960 film Inherit the Wind to contemporary documentaries like Jesus Camp, attempt to emphasize these traits, and thus repeat and reinforce the stereotype of irrational, rural, ignorant "fundamentalist" believers led by a rigid, manipulative, and ultimately hypocritical preacher, who often uses his congregation to gain power, money, or both. As John Weaver illustrates in his recent book, Evangelicals and the Arts in 
Fiction, this perception of conservative Protestants has led to a trope that is repeated frequently with little variation in film and fiction. ${ }^{9}$

Jesus Camp points to the contemporary political context that has inspired an intensification of the traditional stereotyping of conservative Protestants. With the rise of the Christian Right beginning in 1970s, some leaders of conservative Protestant denominations began to cooperate with each other and exert more political pressure by using the moniker "Evangelical," an effort to put the "fundamentalist" past behind them and bridge the gap between self-identified Fundamentalists and other conservative Protestants, especially self-identified Evangelicals (Harding xvi, 16-19). As Harding outlines, this effort created an alliance between some Fundamentalists and some conservative Evangelicals (125-52), but as late as 1996 a majority of those who attended churches that traditionally identified as Evangelical did not support the Christian Right movement (C. Smith 208). Moderate Evangelicals, meanwhile, were completely alienated (Lindsay 884; Wallis). Republicans gradually began to see the value of courting the Christian Right, resulting in a relationship that, while rocky at times, appeared to culminate in the election of George W. Bush. ${ }^{10}$ The Christian Right did not escape the negative associations of "fundamentalism," however. Academics and journalists often use the terms "fundamentalist" and "Evangelical" indiscriminately and interchangeably (Lewis and de Bernardo; Woodberry and Smith; Kellstedt and Smidt). Furthermore, as John Weaver points out, and as Jesus Camp illustrates, the stereotypes themselves have

\footnotetext{
${ }^{9}$ Weaver traces many of the "artistic clichés surrounding evangelicalism” back to Sinclair Lewis's 1927 novel, Elmer Gantry (38). While he acknowledges that many works about evangelicalism, especially early ones, provide a valid and nuanced critique, he argues that the "almost-monolithic presentation of evangelicalism does not allow for alternative views of evangelical belief" forcing left-leaning Evangelicals to see themselves "through this shaming narrative" (31).

${ }^{10}$ For more on the relationship between the Christian Right and the Republican Party, see Williams; Heltzel; Hart; and Harding.
} 
carried over from the "fundamentalists" to Evangelicals, and are applied liberally to mock Evangelicals, and, increasingly, Republicans in general (Weaver; Clark 524). The result helps solidify the connection between Evangelicals and Republicans to the point that the general perception is that to be an "Evangelical" is to be a Republican, and a particularly conservative Republican at that (McDermott 352). While some self-identified Evangelicals like Jim Wallis fight hard to disrupt this association, an increasing number of people who attend churches traditionally identified as Evangelical have begun to reject the Evangelical label in order to disassociate themselves from the Christian Right and Republicans (Lewis and de Bernardo). As a result, Evangelicals are both a political and religious other for "spiritual" Democrats. Evangelicals are the religious group most often treated as a "bad" religion."

\section{The Literary Postsecular}

While Orsi's primary focus in the academy is the social sciences, his critiques apply to the recent theoretical approach to religion in literature referred to as postsecular. John McClure ends his 1995 essay, "Postmodern/Post-Secular: Contemporary Fiction and Spirituality," with an anecdote: a colleague who begins to explore the presence of spirituality in postmodern literature exclaims "I have no language for what I am beginning to see" (160). McClure goes on to say that this is both the promise and the challenge to critics: "the resurgence of spirituality offers criticism yet another opportunity to think again, to recognize and respond to developments it did not for the most part anticipate, and cannot, as yet, perhaps ever, discuss with precision or confidence ... we

\footnotetext{
${ }^{11}$ Since the 9/11 attacks, Muslims have increasingly been represented as a religious other and the epitome of "bad" religion.
} 
find ourselves, like the writers we study, caught up in a reaching; and we are - as postmoderns - wary of grasping" (160-61). Over the next twelve years, McClure does develop a language to talk about the fragmented, politically inflected spirituality he finds in contemporary literature, a language that has gained a stronghold in literary criticism thanks in part to his book, Partial Faiths. Rather than a brand new language, however, it is a strikingly familiar one. The recent studies on the legacy of liberal Protestantism help illuminate the heritage of the language surrounding the literary postsecular that McClure establishes, and critics like Amy Hungerford help to develop. Placing this work on the historical development of religion in the United States alongside literary criticism on the postsecular reveals that this literary postsecular is a clear heir to liberal Protestant ideals, and as a result, suffers from the same limited pluralism that Orsi critiques.

McClure's understanding of the literary postsecular differs greatly from understandings of the term in other fields. The central notion of the postsecular, and the one upon which most scholars who use the term agree, is that a Western understanding of secularism as a universal marker of progress has failed, both because religion has not disappeared and because the notion itself is flawed. Talal Asad's work is particularly influential in disrupting this secularization narrative, and its accompanying binary of religion/secular. He argues that the terms are mutually constituting and culturally dependent. The predominant Western understanding of the secular is not only postChristian, but largely post-Protestant. In an introduction to an anthology on the postsecular, Anthony Paul Smith and Daniel Whistler call the moment we realize that the Western narrative of secularization has failed the "postsecular event" (15). It is not so much that the secular existed and no longer exists, but rather that we realize it never 
actually existed in the way we thought it did. Scholars begin to diverge when faced with the question of what happens next. Smith and Whistler make a stark distinction between two camps. On one side is what they call the "theological appropriation of [the postsecular]" which they also call the "theological virus" infecting philosophy at the present moment (3). On the other is the "legitimate" postsecular, an attempt to find a "generic secular" which sheds the "imperialism" of post-Protestant, Western notions of the secular. Of course, this binary is misleading. On the theological end, there are at least two very distinct camps. Radical Orthodoxy, led by John Milbank and Philip Blond, advocates a kind of premodern orthodoxy with a postmodern twist. Meanwhile, Mark C Taylor and John Caputo build on the work of Derrida to create a weakened, negative theology. The two camps are not complementary. The other side of Smith and Whistler's dichotomy is also not homogenous. While Asad focusses on disrupting the postProtestant bias of Western secularity, scholars like Habermas and Hent de Vries attempt to imagine the ways that largely secular societies can accommodate and co-exist with religious viewpoints. Meanwhile, scholars like Charles Taylor seem to blur the line that Smith and Whistler establish by simultaneously exposing the post-Protestant conditions of belief in contemporary society and advocating belief in "a transcendent reality" (768). In short, there is very little agreement of what the postsecular is, or should be.

John McClure looks to what he calls postsecular fiction by authors like Thomas Pynchon, Don DeLillo, Toni Morrison, Leslie Marmon Silko, and N. Scott Momaday for ideas on what comes next. To do this, he employs what Magdalena Maczynska identifies as a postsecular critical approach to literature to examine the postsecular trend in 
postmodern literature. ${ }^{12}$ McClure defines postsecular fiction using three criteria. First it "trace[s] the turn of secular-minded characters back toward the religious" (3). While most of the novels he studies do meet this criterion, not all of them do. In fact, he dedicates very little of his attention to this criterion and, as a result, critics who have subsequently used McClure's theories tend to bracket this criterion. The second criterion is that the work is a "religiously inflected disruption of secular constructions of the real" (3). This second criterion reflects the common component present in most conceptions of the postsecular. These first two criteria, however, act as the foundations for McClure's third criterion, where he invests most of his energy. Postsecular fiction, McClure argues, presents a “dramatically 'weakened' religiosity with secular, progressive values and projects" (3). This third criterion needs to be unpacked a little. Weakened religiosity, for McClure, is an affirmation of the supernatural without any clear, firm theology or cosmology. As a result, characters explore and experiment with different, and sometimes contradictory, notions of what the spiritual or supernatural might be without fully committing to any of them. While McClure does draw on Caputo and Gianni Vattimo to explain "weak" religion, he spends much more time emphasizing the potential for pluralism that this "weak" religion allows. In it, "all truths are potentially true, all realities are potentially real, but no truth is exclusively true or real" and this leads to what he calls "supernatural multiculturalism" (19). Despite this pluralism, characters and the novels in which they appear do advocate some firm positions. McClure argues that postsecular fiction uses weak religion to help address what he calls "recognizable social

\footnotetext{
${ }^{12}$ Maczynska notes that the critical approach need not be limited to the study of postsecular literature, and that the postsecular trend in literature can be studied using other critical methods, but she goes on to say that, in practice, the two are rarely separate (75).
} 
evils" including "militant nationalism, colonialism, racism, patriarchy, and the ongoing assault on the environment" (20). Though there are never any clear, ultimate solutions, the weakened religion guides characters toward these fights and offers them "a resource for personal and collective empowerment" (13). The resulting postsecular communities are fragile, open, pluralistic, and committed to a long fight of progressive aims. Far from leaving this as simply a trend in literature, McClure envisions his project as prescriptive. At the end of the introduction, he states that he wants to share the "news" he has discovered with "anyone trying to negotiate the difficult terrain where the spiritual and the secular meet in our time" (25). McClure does not just want to see these postsecular communities in fiction; he wants to see them actualized.

Although she never uses the term postsecular in her book Postmodern Belief, Amy Hungerford frames her work as a corrective to McClure's postsecular. While she and McClure take a similar approach, she writes that what distinguishes her work is her attention to "religious and historical context" (3). The result is a much more nuanced sense of how the current trends of religion in literature have developed. Beginning with Emerson, Hungerford describes "belief without content" as belief without doctrine, or at least "belief where [doctrinal] content is the least important aspect of religious thought and practice" (xiv). She links this contentless belief to several different strains of religious thought, including civil religion as it is described by Eisenhower in the 1950s (1-6). Her primary argument, however, is that authors use the language of belief, divested of its doctrinal content, to "create a formal space that we find filled with religious feeling" (xvi). Ultimately, she argues, this space "confers religious authority upon the literary," so that belief without content becomes belief in literature (xv). For example, she 
looks at the way Cormac McCarthy and Toni Morrison mimic Biblical linguistic style, and the way DeLillo's fiction "embodies a Catholic sacramental logic" of immanent transcendence without Catholic theology or overt Catholic themes (53). Furthermore, she argues that authors benefit from this shift by gaining both an abstract position of religious power and tangible benefits of literary renown and bestselling novels. As a result, "belief without content" is a bit of a misnomer; it is instead belief where explicit doctrinal content is replaced by content relating to the place and importance of literature. Hungerford critiques this move, and the authors she studies, because she says that belief without content affords authors the benefits of religious power "without having to answer for [their] assumptions about the world, and about writing" (133). Subsequent critics have used Hungerford's "belief without content" and McClure's "postsecular" interchangeably (for example, see Douglas 334; Belletto 183; Ludwig 89). Both combine a "weak" affirmation of the spiritual with supposedly secular projects. The same authors who use the language of belief to confer religious feelings on the literary also use that language to confer similar religious feelings on what McClure calls progressive politics. In using the terms interchangeably, however, the correctives that Hungerford performs in her work become lost to some degree. ${ }^{13}$

If McClure does not repeat the problems of liberal Protestant pluralism that Orsi points out, he comes dangerously close. In his chapter on Native American authors N.

\footnotetext{
${ }^{13}$ McClure and Hungerford are not the only two literary critics to engage with the postsecular. Michael Kaufmann has written two articles on postsecular literature ("The Religious"; "Post-Secular") and edited a special forum in Religion and Literature called "Locating the Post-secular." His approach, which draws a great deal on Asad, is to examine the way the literature troubles and contextualizes the religious/secular dichotomy. His understanding of the postsecular has not, however, taken hold among literary scholars as much as McClure's understanding. For example, in the Religion and Literature forum, only two of the contributors refer to Kaufmann in order to situate the literary postsecular while all six contributors build on McClure's theories.
} 
Scott Momaday, Leslie Marmon Silko, and Louise Erdrich, he appears to present a "rationalized and sanitized" version of Native spirituality. McClure is careful to acknowledge the way that Native Americans have been fetishized as "repositories of a subversive sacred knowledge by cultural prophets," and the role this fetishization has had in colonial projects (138). He will, he assures his readers, proceed with "caution" (138). Yet, later in that chapter, he argues that the "goal of visceral return to the planet is the common property of postsecular fiction, but it is most powerfully dramatized in these Native American novels" (151). Native American fiction becomes the repository of a more "powerfully dramatized" environmental politics that is common to all postsecular fiction. By the final lines of the chapter, Native American fiction becomes one example among many of "the dream ... of a restored relation to nature and the dream ... of new modes of religious being strong enough to empower the weak and weak enough to prevent a slide into fanaticism" (161). McClure contextualizes these "dreams" using Vattimo, William Connolly (a noted advocate of a liberal Protestant inflected pluralism) and, of course, William James.

McClure also participates in the religious dichotomization of "good" and "bad" religion along liberal/conservative lines. In one section of his introduction, he explicitly contrasts the postsecular with Christian fundamentalism. Unlike the postsecular, fundamentalism ascribes to "inerrant scripture," "incontestable doctrines and codes," "uniformity of belief and practice," and finally, its "elite leaders who are deemed to be unassailable in their authority over contemporary belief and praxis" (8). This becomes a reoccurring positioning throughout the book: on one side is the secular, and on the other is the "totalizing language of dogmatic theology" (16) of fundamentalism. The 
postsecular is comfortably in the middle. Since McClure is committed to the postsecular project himself, this is not simply a situating of a trend he finds in literature; he is also situating himself. As a result, he does what Orsi argues many critics do: McClure creates an us/them dichotomy, in which he is part of the moderate "us," and the "fundamentalists" of "bad" religion are "them." Other critics who take a postsecular approach to literature repeat this positioning so often that Michael Kauffmann satirizes it. He says that "part of the agenda of postsecular literary criticism is to reassure our colleagues with something like this message: 'Even though we question secularity and secularism, even though we see value in religious belief and practice, we are definitely not like those scary fundamental religious absolutists"” (72). Kauffmann agrees with Laura Levitt and David Watt, who argue that this positioning ends up reinscribing a binary, and Protestant bias already present in a post-protestant "secular," a bias that scholars like Asad are trying to disrupt. Hungerford is a refreshing exception to this trend. While she acknowledges the tendency of post-liberal Protestantism in the form of "belief without content" to contrast itself with evangelicals in the United States, it is difficult to detect any privileging of this form of post-liberal Protestantism in her work given her direct critique of it in her conclusion. In fact, in one chapter she provides a thoughtful analysis of the way Tim LaHaye's Left Behind series uses some of the same techniques that postsecular authors use, though to different ends. Instead of framing conservative Protestants as an undesirable other, as McClure does, Hungerford examines evangelical literature with the same vigor and attention as other works. Unfortunately, few critics have followed her lead in this kind of nuanced analysis of Evangelicalism in relation to the postsecular. 


\section{Neo-Liberal Spirituality and the "New Age"}

Scholars who study the liberal Protestant legacy often identify the "New Age Movement" as an heir to liberal Protestant ideals. Leigh Eric Schmidt, for example, tries to connect the "New Age" spirituality promoted by Oprah with liberal Protestantism (285). The problem with this line of argument is the term "New Age" itself. Matthew Wood provides a detailed summary of the theoretical approaches to the New Age in the introduction to his recent fieldwork project. The academic consensus seems to be that what unifies the New Age movement is the "primacy of self-authority . . . [it] is seen as a religion — or more usually, a spirituality — in which people choose what to do, and how to do it based on their own authority, rather than being directed by authorities external to them" (2). This self-authority manifests itself in the variety of eclectic practices and beliefs presented to individual practitioners who are then able to sample, mix, and match in an ongoing experimentation and exploration. The real subject of this exploration is not the religions, but the self. As a result, the New Age movement, as it is conceptualized in a scholarly context, is one of the top two targets of those who study the relationship between neoliberalism and religion (the other being Evangelicalism). Wood, however, objects to the term entirely, arguing, "no case has been convincingly made that an area of religious belief and practice that can be described as New Age exists" (9). Those that do try to make the case lack "theoretical underpinning, empirical evidence and comparative considerations" (9). He even suggests that the term New Age is most often used by religious groups or academics who want to critique minority religions. Groups rarely, if ever, use the term to self-identify in spite of the fact that critics continue to use it 
(Chandler 70). Furthermore, not all of the groups categorized as New Age promote the individualized, self-spirituality commonly identified with the movement. In fact, Wood points to two scholars whose early work identifies the New Age as a movement of selfcentered spiritualties, but who now argue that what they thought was the New Age was simply "one manifestation of a general shift in religion toward spirituality, in particular toward Self-spirituality" (21). One of those scholars, Wayne Clark Roof, has found that that those who continue to self-identify as liberal Protestant consume a large amount of materials that are either marketed as New Age, or that promote the individualized spirituality commonly associated with the New Age label. In other words, not all participants in religious groups labeled as New Age promote self-authority in terms of spirituality, while many groups not categorized as New Age do promote this selfspirituality. Wood concludes that the only value of the term New Age in an academic setting is that it serves in an analysis of how the term has been deployed as a brand for books, music, and other goods and services.

Even using the term "self-spirituality" does not acknowledge the shift from a spirituality that is liberal to a spirituality that is neoliberal. Like liberal Protestantism, liberal spirituality prioritizes liberal values and ideals over other moral and spiritual values and concerns; these liberal values become the guiding values upon which religious and spiritual activity is judged. This prioritization compliments a greater emphasis on religious exploration, in which liberal Protestant congregation members were encouraged to assimilate pieces of other religious traditions which could support these broader liberal ideals. Liberal spirituality maintains this focus but sheds the attachment to the institution, allowing individuals to experiment much more broadly. This is the kind of spirituality 
that Luckmann, Bibby, and Bellah describe. ${ }^{14}$ This form of spirituality rose in prominence during the 1960s when large numbers of people left liberal Protestant churches. Not everyone who practices liberal spirituality formerly attended a liberal Protestant church, but the liberal Protestant approach to religion along with its Protestantinflected liberal values were dominant in the United States for so long that it inevitably had a strong impact on the development of most forms of liberal spirituality and their participants. Neoliberal spirituality redefines classic liberal terms with a market inflection, making spiritual exploration an entrepreneurial endeavor with an end goal of increasing self-value. Though it is difficult to identify a starting point for this kind of spirituality, the 1990s represents a moment when this kind of spirituality was widespread in the United States. In order to fully understand neoliberal spirituality, it is important to understand how neoliberalism redefines classic liberal values like freedom and individuality.

Neoliberalism is most commonly understood as a series of economic policies which favour the free market and limit regulation. Thomas Lemke summarizes the resulting shift in the relationship between the government and the economy: "Unlike the state in the classical liberal notion of rationality, for the neo-liberals the state does not define and monitor market freedom, for the market is itself the organizing and regulative principle underlying the state. From this angle, it is more the case of the state being controlled by the market than of the market being supervised by the state" (200). Most critics, including David Harvey and Stuart Hall, point to Ronald Reagan's election as president in 1980 (along with Margaret Thatcher's election in Britain in 1979) as a major

\footnotetext{
${ }^{14}$ See note 1.
} 
step in the "neoliberal revolution" (Harvey 39; also see S. Hall 705). Both acknowledge, however, that neoliberalism got its start in the United States not long after World War II, when a group of radical economists and political scientists, including F. A. Hayek, George Stigler, Gary Becker, and others based in the Chicago School of Economics, theorized neoliberalism. ${ }^{15}$ As Jamie Peck suggests, "there is no bee line trajectory" from this theorization to the current neoliberal conditions in the United States, but rather an "uneven and uncertain progress, from its inauspicious beginnings as a reactionary cult [the Chicago School], through its moments of vanguardist advance, to its effective mainstreaming" (xii; xi). Harvey agrees, suggesting that "the capitalist world stumbled towards neoliberalization as the answer through a series of gyrations and chaotic experiments that really only converged as a new orthodoxy with the articulation of what became known as the 'Washington Consensus' in the 1990s" (39). Along with Harvey, critics tend to identify the 1990 s as a point when neoliberalism became normalized in the United States, giving rise to what Patricia Ventura calls an "American neoliberal culture" (4). Hall, Harvey, and others outline the variety of circumstances which allowed neoliberal economic policies to become the norm in American politics. One of these circumstances, argues Harvey, is the adoption of a neoliberal conception of the self.

In his 1979 lectures titled The Birth of Biopolitics, Michel Foucault examines the neoliberal self. Rather than conduct sociological research or analyze popular culture, Foucault draws on the Chicago School's theoretical writings from the 1960s, especially

\footnotetext{
${ }^{15}$ Foucault notes the strong influence German Ordoliberalism of the mid twentieth-century had on the Chicago School. Furthermore, as Patricia Ventura notes, Foucault takes a "very long view" of foundation of neoliberal ideas which extends back to ancient Greece. Despite this extended view of its origins, Foucault maintains that what the American brand of neoliberalism does is different than anything that came before (Ventura 5).
} 
those of Gary Becker, whom Foucault sees as "the most radical of the neoliberals" (269). Becker applies neoliberal economic principles to decisions which are not typically considered economic (i.e. criminal activity, sex, marriage, etc.); rational choices are made based on a self-interested, cost/benefit analysis. Foucault argues that this approach to decision-making repositions the individual as an "entrepreneur of himself . . . being for himself his own capital, being for himself his own producer" (269). The goal of this entrepreneur of the self is not to earn money, but rather to use the resources available (both financial as well as emotional, temporal, etc.) to "produce his own satisfaction" (Foucault Birth 269). As Andrew Dilts suggests, “entrepreneurial activities and investments are the most important practices of the neo-liberal self. And there are literally no limits on what could be re-considered now as a form of entrepreneurial activity" (137). Michael Feher uses this as a way of distinguishing between liberalism and neoliberalism: "from a liberal perspective, love, religion, and culture cannot be reduced to a mere calculus of interests: they delineate an existential realm where human desires are not optimally managed through bargaining and the interplay of selfinterested exchanges," whereas, from a neoliberal perspective, everything, including religion, can be reduced to an entrepreneurial activity designed to increase self-fulfilment and selfvalue (23). As a result, individuals are encouraged to view themselves as "a collection of skills or traits that can enter into alliances with other such collections" (Gershon 539). Self-appreciation accumulates based on the value you place on the skills and traits you have acquired, a value which is influenced by your perception of the market value of these traits and skills. Relationships in this figuration become "two or more neoliberal collectives creating a partnership that distributes responsibility and risk so that each can 
maintain their own autonomy as market actors" (Gershon 540). In this context, religion is "a set of traits or even skills that people can possess" to appreciate their value. They can then use religion in the same way they use culture: they can "consciously deploy their [religion] to engage with the market to their advantage" (Gershon 541). As a result, individuals become entrepreneurs of religion as well as of themselves. They construct religions from a well of resources in the form of both traditional religion and, more often, repackaged versions of those religions. The goal is to find the right combination that appreciates them as people in terms of their self-worth and self-fulfillment while giving them an advantage in the open market of human relationships.

One of the important parts of the widespread acceptance of neoliberalism has been the assimilation of the neoliberal redefinition of key classic liberal terms like individualism, autonomy, democracy, and rationality. Hall explains this most succinctly: neoliberalism "borrows and appropriates extensively from classic liberal ideas; but each is given a further 'market' inflexion and conceptual revamp" (711). As Harvey notes, this is not an amorphous system of neoliberalism which redefines the terms, but rather the theorists of neoliberalism from the 1960s and their earlier influences. Rational choices, for example, are choices based on self-interest which take the market into account. Meanwhile, Harvey cites Karl Polanyi's redefinition of freedom as a way of overcoming the "'moral obstacle' of liberal utopianism ... Free enterprise and private ownership are declared to be essentials of freedom. No society built on other foundations is said to deserve to be called free. The freedom that regulation creates is denounced as unfreedom; the justice, liberty and welfare it offers are decried as a camouflage of slavery" (Polyani cited in Harvey 38). Refiguring individuals as entrepreneurs of themselves who 
participate in various social markets aligns them more closely with businesses and corporations. As a result, it is less of a leap to consider corporations as people. Regulations on the free market that limit the activity of corporations seem less an act of governing the economic sphere, and more an act which infringes on freedom in general, including the freedom of the individual. Harvey argues that these redefinitions have become so "common sense" in the United States that "Any political movement that holds individual freedoms to be sacrosanct is vulnerable to incorporation into the neoliberal fold" (41). The simultaneous redefinition of key classic liberal terms along with the refiguration of individuals as entrepreneurs of themselves helped to pave the way for the neoliberal economic policies of Regan, and later, the "Washington consensus" in the 1990 s. ${ }^{16}$

This dramatic redefinition of the individual and individual freedoms has a far greater impact than elections and support for economic policies. It changes the way people understand themselves and their lives. There are several ways to measure and study how this neoliberal self-appreciation and self-improvement took hold in the United States. Nikolas Rose, for example, examines the way a neoliberal understanding of the self appeared in health care, education, and the military. More relevant for this study is the shift in self-help literature. Micki McGee argues that the self-help industry, largely based on books, experienced a boom in the early 1990s: "self-help book sales rose by 96 percent in the five years between 1991 and 1996. By 1998, self-help book sales were said

\footnotetext{
${ }^{16}$ Another major impact of this shift in terms of both economic policies and governmental elections is the downloading of responsibilities onto individuals and private groups. As Lemke suggests, "Neo-liberalism encourages individuals to give their lives a specific entrepreneurial form. It responds to stronger 'demand' for individual scope for self-determination and desired autonomy by 'supplying' individuals and collectives with the possibility of actively participating in the solution of specific matters and problems which had hitherto been the domain of state agencies specifically empowered to undertake such tasks" (202)
} 
to total some $\$ 581$ million" (11). This is the same period of time in which Oprah announced a new direction for her show which closely aligns with a self-help mandate. Of course, self-help books did not originate in the early 1990s. ${ }^{17}$ Both McGee and Sabine Maasen argue that there is a noticeable difference between the self-help books in prior periods and the ones produced during the 1990s boom. Maasen looks at the difference between 1920s self-help books and those of the 1990s. She finds that "in the 1920s, instruction books focused on the goal of success in the work sphere and on how to proceed methodically in order to reach this goal. In the 1990s, self-management manuals encouraged their readers to set their goals for themselves" (117). These goals are constantly changing, depending on "inner and outer circumstances" (117). Unlike the 1920s manuals, in which the ultimate goal is occupational and financial stability, the 1990s manuals focus on self-fulfillment, which requires not only career goals, but emotional, social, even spiritual goals, along with a constant re-evaluation of those goals. Maasen argues that the focus in the 1990s self-help books on "continuous decisionmaking" aligns them with neoliberalism (117). Similarly, McGee contrasts the 1990s self-help books with "the self-made man of the nineteenth and early twentieth centuries [who] aimed to achieve success in terms that were largely external and measurable—-for example, accumulations of wealth, status or power" (19). By contrast, "late-twentieth century self-making involves the pursuit of the rather more elusive and variable state of self-fulfillment. With the emergence of an emphasis on self-fulfillment, one finds there is no end-point for self-making; individuals can continuously pursue shifting and subjective criteria for success" (19). This seems to suggest an unstable self which changes based on

\footnotetext{
${ }^{17}$ Barbara Cruikshank, for example, focuses on the self-esteem movement in the 1980s and what Gloria Steinem calls "biblotherapy" as supporting a neoliberal conception of the self (89).
} 
external (read market) circumstances. McGee notes that this is not the case:

"Paradoxically, the imperative of inventing the self that is found in literatures of selfimprovement is often cast in the form of discovering or uncovering an authentic, unique, and stable self that might function — even thrive — unaffected by the vagaries of the labour market" (16). This stable self is able to make self-interested rational decisions based on the various markets it encounters, whether they be social, labour, or religious/spiritual; the markets do not change the individual, but rather the best individuals adjust to the market. Self-help books offer readers a way of realizing themselves as entrepreneurs of themselves, treating their social interactions as market exchanges which they can use to produce self-fulfillment. It is no coincidence that it is during this self-help boom and general acceptance of neoliberal economic policies that "Spirituality" becomes a section in many bookstores and experiences its own boom. Spirituality books reinterpret and appropriate religious and spiritual traditions in order to help self-entrepreneurs mine the resources of those traditions in order to produce their own self-fulfilment.

The borders between liberal spirituality and neoliberal spirituality are extremely porous. While some individuals may whole heartedly embrace neoliberalism and explicitly frame their religious choices in market terms, using spirituality as an asset to help them raise their self-fulfillment and self-value, others may cling more to classic liberal values that bear only slight evidence of neoliberal market inflections. Further complicating clear borders in these definitions is the way some institutions adopt a neoliberal approach to religion by translating various theologies and religious practices into neoliberal terms and aggressively marketing themselves to potential 
converts/religious consumers. ${ }^{18}$ These labels, then, are best understood as points on a continuum. The narratives in this study fall somewhere along the continuum. Some, like the narratives of Megan Fox and Katy Perry, are explicitly neoliberal, while others, like that of Kim Barnes, favour liberal spirituality with only traces of the way neoliberalism defines rationality. ${ }^{19}$

\section{The Marketplace for "Spiritual” Books}

For authors, deploying religion and spirituality is an important asset in the competition for book consumers. In the late 1980s, publishers began to realize that those who had left liberal Protestant churches during the 1960s were still interested in spirituality. A survey of Publishers Weekly reveals that publishers and booksellers began to construct a profile of a "spirituality" readership: it is made up of "disaffected church goers" (Carrigan "Reinventing" S4) who "seek a variety of paths toward enlightenment" (Carrigan "For Every" 36); "unaffiliated readers who are also an educated audience" (Nelson "Losing"16) and "very serious about their spiritual lives" (Steve Scholl, qtd. in Nelson "Losing” 17; also see Nelson "Gimme That" S7; Schlumpf S8). Like the liberal Protestant readership Hedstrom describes, publishers imagine this group to be interested in drawing from numerous sources to construct their own personalized religion with clear practical benefits. Unlike earlier liberal Protestants, however, they are much more suspicious of religious institutions. As a result, these books cannot be labeled as "religion" books. Publishers are very clear that this readership "isn't going to go into the

\footnotetext{
${ }^{18}$ Joanildo Burity examines the way some Pentecostal denominations and liberal Protestant organizations use similar marketing strategies and language to attract people to what are very different religious traditions.

${ }^{19}$ More work is required to fully explore and historicize neoliberal spirituality.
} 
religion section" (Marcia Broucek, qtd. in Schlumpf S8); "people who shop for one ['Spirituality'] aren't interested in shopping for the other ['Religion']" (Donald Levy, qtd. in Schlumpf S9). The term religion "carries the negative baggage associated with rules and regulations, doctrine and dogma" (Schlumpf S4). Books shelved in the "religion section deal with more traditional 'Bible Belt' materials" (Mary Gay Shipleg, qtd. in Bachleda 36). Spirituality books are written by "authors who are either not clergy or, if they are, have somehow had the denominational label sandpapered off them" (Thomas Cahill qtd. in Spalding 80).

Initially, publishers and booksellers labeled these non-religious books as "New Age," but they later found that the category was not taken seriously. As one publisher told Publishers Weekly, "[New Age] implies crystals, candles, channeling (Robert Hall qtd. in Nixon 21), all of which do not adequately address "more serious spiritual pursuits," (Nixon 21). In its place, "Spirituality" became a subject category and a section in many bookstores by the mid-1990s. Publishers understood that this shift was simply one rebranding in a perpetual series of rebrandings for the subject area: "the vocabulary will invariably change" but the books will continue "to grapple with the same basic human issues" (Clayton Carlson, qtd. in Spalding 80). In other words, publishers rebrand the same kinds of books, along with the same approach to reading and consuming books as a spiritual exploration, in order to make those books appear to be a source of "fresh and vivifying light," and keep the "spirituality" audience buying the books. The result is that bookstores become "the place many carry out their quests ... Since it is obviously less daunting to take religious questions to a bookstore than seek out the local priest, rabbi, or minister" leading readers to discover "once again the potentially life-changing 
power of the book" (Garrett "The Power" S3). Fiction increasingly became part of this spiritual quest, thanks in part to Oprah's book club and the kind of reading it promotes (Winston S13). Appealing to this spirituality market opens up particular kinds of publishing and promotional opportunities. In some cases, those opportunities lead to lucrative sales and even literary awards (Hungerford 133).

\section{Promoting the Spiritual Self}

Authors can appeal to this market and position themselves as "spiritual" by displaying the proper spiritual disposition. Bradford Verter suggests that a "spiritual disposition ... is the knowledge, abilities, tastes, and credentials an individual has amassed in the field of religion, and is the outcome of explicit education or unconscious processes of socialization" (159). As with postsecular literature, it is less the content of an individual's religious or spiritual practices that is important, and more the form of that practice: how an individual understands religion, how an individual consumes religion and spirituality, and how an individual talks about or displays their religious and spiritual practices. For example, "someone who considers herself a Buddhist but attends seders, practices Yoga, consults an astrologer, wears a crystal, and professes an interest in American Indian spirituality" signals a particular approach to religious pluralism based on a consumer oriented approach to religion that Verter calls "spiritual omnivorosity" (167). Verter goes on to suggest that "conspicuous displays of familiarity with multiple religions further serve the dual function of maximizing one's social network while minimizing the appearance of investment" (168). Minimizing the appearance of investment (or attachment) to any particular religion serves two distinct purposes. First, it 
is "an important defensive strategy ... because the value of spiritual capital in porous, heterogeneous communities (as opposed to isolated, traditional ones) is inherently unstable" (168). For example, the value of wearing crystals may at one point be high because it is fashionable and endorsed by leading celebrities, and then fall in value due to negative associations with misconceptions about the New Age in popular culture. Displaying a lack of investment combined with a multiplicity of religious or spiritual involvement allows the individual to discard less valuable practices in favour of more valuable ones without excessive explanation. Verter hints at the second function, but does not fully explore it. Minimizing the appearance of investment allows individuals to further distinguish themselves from conservative "religious" (as opposed to "spiritual") individuals. While the conservative "religious" seem heavily invested in a particular set of religious practices and beliefs that appear more or less static, the "spiritual" appear less invested and more fluid in their practices and beliefs. This distinction is particularly important in deconversion narratives, where one of the primary functions of the narrative is to position an individual within a new religious community by virtue of his/her rejection of the old religious community. Drawing on Bourdieu, Verter argues that displaying the right spiritual disposition affords individuals a kind of spiritual capital. Like cultural capital, however, "its efficacy resides in the fact that it is not recognized as capital - that is, as the product of a primitive accumulation within a struggle to impose an arbitrary symbolic hierarchy—but rather is mistaken for competence within a naturalized social order" (159). The groups who value the spiritual dispositions that Verter describes here consider those dispositions to be natural and normal— the proper disposition for rational, independent individuals. It is the disposition of what Orsi calls "good" religion. 
Those who do not share this disposition, therefore, are abnormal and ascribe to "bad" religion. Authors who display and deploy the right spiritual disposition can gain spiritual capital with a potential reading audience, giving them access to the market of "spiritual" readers.

The clearest way that authors display a "good" spiritual disposition is in the content of their writing. Books that promote a vague kind of spirituality that is compatible with individualism, freedom, pluralism, tolerance, democracy, and intellectual inquiry have the potential to appeal to spiritual readers. For fiction writers, appealing to this potential market is a little more complex. Incorporating the characteristics that McClure and Hungerford note in their work on postsecular literature with an accessible, middlebrow style is a vital step toward appealing to this market. However, the content of the books is only the first step. Authors, along with their publishers, bookstores, and media outlets must promote the books in order to gain an audience.

Interviews with authors are an important piece of these promotional efforts. In his study of American literary celebrity, Joe Moran argues that while author interviews have helped promote literary figures for centuries, they became increasingly important beginning in the 1980s as publishers "realized the cheapness and effectiveness of forms of publicity which focus on the author-magazine and newspaper features and television and radio appearances—over paid advertising" (37). These media appearances promote "authors as 'personalities' ... a symptom of the continuing integration of literary production into the entertainment industry, making authors and books part of the cultural pervasiveness of celebrity as a market mechanism" (41). Moran draws on Andrew 
Wernick who argues that an author, sometimes in consultation with a publicity team, becomes "a self which continually reproduces itself for competitive circulation" (193). Moran even cites instances where publishers make decisions about whether or not to publish a first-time author based on his or her "attractiveness or screen presence" (37). The promotion of books and authors, however, is not balanced. Moran suggests that publishers tend to pour more of their promotion budget and efforts into a relatively small number of authors who will have mass appeal, leaving the rest to promote themselves. These leftover authors have increasingly begun to find "niche" markets (43). An author may have to develop a complex persona which balances openness and reluctance toward self-promotion and which somehow stands out enough to catch the attention of potential book consumers. Deploying the right spiritual disposition, however, is part of this process, especially when an author writes about religion and spirituality in either fiction or memoir. Displaying the right spiritual disposition is the first step to gaining access to a "spiritual" market with consumers that will buy books and align itself with particular authors.

Of course, authors are not alone in trying to gain a market advantage with a "spiritual" audience. Celebrities and politicians frequently attempt similar performances in speeches and interviews. President Barak Obama is an excellent example. Obama frequently appears to talk openly about his faith in speeches, interviews, and his own books, but the way he speaks about it is carefully crafted to fit within a liberal conception of religion. In most instances, he highlights the multiplicity of religious influences from his childhood. Obama went to a Catholic school but was influenced by Eastern religions while he was growing up in Hawaii. He also says he has a lingering intellectual attraction 
to Judaism (Falsani). His father was an agnostic Muslim, but perhaps the biggest influence was his mother. While she had "a healthy skepticism of organized religion" ("Building"), Obama says "[she would] spend a lot of time talking about values and give me books about the world's religions, and talk to me about them. And I think her view always was that underlying these religions were a common set of beliefs" (qtd. in Falsani). When Obama became a young adult, his spiritual searching remained linked to reading. He read St. Augustine, Nietzsche, Catholic novelist Graham Greene, and then later Paul Tillich and Reinhold Niebhur with equal interest. When he finally converted to a liberal Protestant Christianity, Obama says he was inspired by the "African-American religious tradition to spur social change" ("Building"). In the mid 1980s a group of churches in Chicago came together to fight against urban development and hired him to organize their activities. He began attending a church in this context in order to perform his job better and remain attached because his "intellectual view of religion deepened" (Falsani). He maintains that this conversion was "a choice ... The questions didn't magically disappear" ("Building"). To emphasize this point even further, he later identifies himself as a "Christian by Choice" in a 2010 speech (qtd. in Babington and Superville). He justifies this continued choice by the benefits it offers him: it "sustains" him while he endures particularly vicious political and personal attacks. In spite of this choice, he remains committed to "a pluralistic society . . . grounded in the JudeoChristian tradition" ("Building) in which "Jews, Muslims, Hindus, atheists, agnostics, [and] Buddhists [all have] their own path to grace" (qtd. in Babington and Superville). It is no wonder that the New York Times called Obama a liberal Protestant par excellence. He is committed to a religious pluralism rooted in liberal values. He used books to 
explore his religious options before settling on a Christianity which prioritizes political action over belief in the supernatural.

Obama also deploys religion for a market advantage. In 2005, after George W. Bush won his second presidential election with strong support from conservative Evangelicals, the Democratic Party held a series of meetings known as the Faith Working Group in order to find ways of winning the "God vote." Shortly after those meetings, the Democratic National Committee instituted several programs designed to court religious leaders as well as train Democratic candidates to talk about political issues in religious and spiritual terms. Obama is, in many ways, the culmination of those efforts. Not only has he spoken frequently about the way his faith motivates his social policies, but he has reached out to the growing Evangelical left. Obama's deployment of his religion has not been entirely successful. Despite numerous interviews and public statements in which Obama tells his conversion story, a survey conducted in 2011 found that just over a third of Americans believe Obama is a Christian. While a startling number of people believe he is a secret Muslim, that number does not account for the entire two thirds. Many believe Obama is pretending to be a Christian in order to win votes. The authenticity of Obama's professed beliefs does not change the fact that he deploys them strategically in order to give himself a market advantage, and that this deployment is part of an open, widely reported strategy of the Democratic party.

Finally, Obama uses conservative Evangelicals as foils to his liberal approach to religion. Obama overtly rejects "the Jerry Falwel1/Pat Robertson style of rhetoric" of his Republican opponents because of the "insular views of faith" it promotes, its "preachy" tone, and its commitment to "the inerrancy of the Bible" ("Building"). He even contrasts 
his own conversion, based on rational, individual reasoning, to stereotypical Evangelical conversions by asserting that he did not have "an epiphany" and he does not "fall out in church" ("Building"). Falling out is an ecstatic religious experience common in Pentecostal and charismatic churches where an individual appears to faint in a trance. Obama sets up a dichotomy in which the liberal approach to religion is the rational. You are either a narrow-minded dogmatist who surrenders your autonomy and votes Republican, or you are a rational individual, who makes decisions which take into account the costs and benefits in order to best suit your personal goals, whether they be social, emotional, spiritual, or political.

\section{Conclusion: Markets, Audiences, and Neoliberal Community}

There is an irony in the fact that scholars who examine neoliberalism and religion tend to focus on conservative Evangelicals more often than the contemporary "spirituality" marketplace. This is partly because conservative Evangelicals construct religious justifications for Republican neoliberal economic policies, and they celebrate the fact that these policies appear to embrace neoliberalism much more than policies of the Democratic Party. The adoption of neoliberalism, however, goes much farther than a religious justification of economic policies. As Andrew Strombeck suggests, recent Evangelical literature presents conversion as "a simple matter of market logic ... Faith, like good investing or consuming, is merely a matter of making good observations and acting on them. [Evangelicals], then, act in accordance with what neoliberalism demands of its subjects: that they be rational actors in all spheres" (182). From an Evangelical perspective, becoming an Evangelical is a rational, self-interested choice which best 
enables an individual to achieve self-fulfillment. If both conservative Evangelicalism and neoliberal spirituality embrace neoliberal terms for making decisions, then the decision between the two is similar to the decision between neoliberal Democrats and Republicans. Feher describes that decision as "a contest between different ways of appreciating and of valuing oneself, a competition over the conditions and modalities of the valorizing of human capital, over what behaviors deserve to be included in my portfolio because they allow me to appreciate and to value myself" (Feher 31). No matter what the conclusion, however, it is a decision which embraces a neoliberal conception of religion. Despite the way neoliberal spirituality frames the choice offered to individuals, it is not a choice between systems, but rather how you participate in the same system.

There is a diverse and dispersed group of consumers participating in a religious marketplace under the illusion of autonomous, individual choice. Authors appear as simply one more market competitor in this bleak portrayal. Scholars often address this religious marketplace by critiquing the New Age for jettisoning community in favour of individual consumerism. Siobhan Chandler defends New Age spiritualties against these critiques. She says "the market operations of New Age spiritualties mobilize its message in the form of goods and services and operate as an important institutional bulwark against dissolution and insignificance. In other words, the market enables [liberal] spirituality to express itself in civil society just as it allows churches, labour unions, feminist organizations, and other groups to do so" (84). For Chandler, the marketplace is not a replacement for community, but rather the basis of community. This fits very well with a neoliberal perspective. Communities become groups of consumers who not only agree on the conditions and modalities of valorizing of human capital, but participate in 
the marketplace by purchasing goods and deploying their beliefs to gain an advantage. Chandler links this market mobilization to various left wing activist groups, but rather than deflect the critique, this link demonstrates how far neoliberal perspectives have infiltrated supposedly progressive political movements. Chandler's defense does cast a somewhat different light on authors who try to penetrate the spirituality market, especially those writing deconversion narratives. Instead of simply trying to gain a market advantage, they may genuinely desire a community to replace the one they have lost in leaving Pentecostalism. They sometimes channel that desire through neoliberal conceptions of religion which collapses the distinction between a community and a market. This community/market celebrates the liberal values of individualism, freedom, pluralism, tolerance, democracy, and intellectual inquiry, but undermines those same values by restricting individuals to a neoliberal conception of rational choice based on the marketplace. It also exemplifies the persistent legacy of liberal Protestantism by deemphasizing theological specifics in favour of liberal values, which are in turn linked to a marketplace, specifically, the marketplace for books. 


\section{Chapter Two}

\section{Put Away Childish Things: Kim Barnes and the Coming-of-Age Deconversion Narrative}

In an interview with Robert Root Jr. for Fourth Genre, Kim Barnes talks about the evolution of her two memoirs, In the Wilderness and Hungry for the World. Before turning to memoir, she began by writing autobiographical poems and short stories. The stories, in particular, did not accomplish what she wanted them to:

When I would read in public_-for instance, a scene of faith healing in the church—everyone would laugh uproariously. I realize now that I had depended, as a part of the story, on a kind of Flannery O'Connor-like absurdity, what I call western grotesque. How else do you deal with people falling down, rolling in the aisles, speaking in tongues? It seems absurd to many people; it takes on a certain humor ... they never felt quite right to me because that wasn't what I was trying to promote, that wasn't the truth or the most honest aspect of these stories ... They were coming-of-age stories. (172)

To compensate, Barnes began rewriting the stories as a memoir. The initial result was her first book, In the Wilderness: Coming of Age in an Unknown Country (1996). In it, she tells the story of her family's conversion to Pentecostalism when she is six and her subsequent deconversion after she finishes high school. The first half of her follow-up memoir, Hungry for the World, retraces many of the stories found in her first book. The second book, however, shares a more detailed account of what happens after she leaves Pentecostalism and her home behind. Ultimately, Barnes is in the same place at the end 
of both books: she is trying to negotiate a tenuous relationship with her past and her parents, while celebrating her freedom to search, experiment, and choose for herself - even if that leads to negative consequences.

By framing her memoirs as coming-of-age stories, she facilitates this negotiation. Rather than dismissing the Pentecostalism of her childhood and of her father, entirely, she finds a way to develop it as well. As a result, the Pentecostalism of her childhood becomes simply the underdeveloped, childish version of her current, more developed and mature spirituality. This framing also helps her negotiate the paradox of identity in deconversion narratives. As mentioned earlier, deconversion narratives often deal with competing notions of identity. First, a concept of identity as unstable and subject to change (in this case, an old Pentecostal identity and a new unaffiliated spiritual identity) allows authors to emphasize the contrast between the old life and the new. Second is a concept of identity which is stable, but can be either incomplete or fully realized. Framing a deconversion narrative as a coming-of-age story, as Barnes does, draws on the latter concept more than the first. At the same time, portraying the old, underdeveloped identity as childish allows her to maintain a clear contrast between her current, adult spirituality and her past Pentecostalism.

The problem with this construction is that it casts current, practicing Pentecostals as antiquated, infantile, underdeveloped and under-educated. This characterization manifests itself differently for her mother and father. Pentecostalism restricts her mother's development and Barnes outgrows her mother by breaking free from the restrictions of Pentecostalism. In essence, Barnes represents her mother as a victim of Pentecostalism. Her father, meanwhile, seems to personify Pentecostalism. While he has 
both the skills of rational inquiry and a commitment to a spiritual quest, Barnes represents him as failing to fully develop either. At the same time, the restrictions he rigidly imposes on her prevent her from realizing her full "potential.” Barnes plays on Pentecostal stereotypes to make her parents, and Pentecostalism in general, seem backwards. In contrast, her own vague spirituality, including the bits she has pilfered from Pentecostalism, comes across as more advanced and modern.

\section{Coming-of-Age Deconversion Narratives}

Coming-of-age stories can take numerous forms; however, since the nineteenth century, these forms tend to wittingly or unwittingly draw on bildungsromans.

Bildungsroman is a contested term among scholars, with some arguing it should only apply to novels produced in nineteenth century Germany. Other scholars have pushed for a broader definition which acknowledges the widespread influence these nineteenth century German novels have had on subsequent narratives about growing up. One of the most often cited definitions of bildungsromans comes from Jerome Buckley. In his 1974 book Seasons of Youth, he tries to make a case for an English tradition of bildungsromans, thereby justifying the continued usage of the term. He argues that these works feature

a child of some sensibility [who] grows up in the country or in a provincial town, where he finds constraints, social and intellectual, placed upon the free imagination. His family, especially his father, proves doggedly hostile to his creative instincts or flights of fancy ... He therefore, sometimes at quite an early age, leaves the repressive atmosphere of home (and also that 
relative innocence), to make his way independently in the city ... There his real "education" begins, not only his preparation for a career but also — and more importantly—his direct experience of urban life. The latter involves at least two love affairs or sexual encounters, one debasing, one exalting, and demands that in this respect and others the hero reappraise his values. By the time he has decided ... the sort of accommodation to the modern world he can honestly make, he has left his adolescence and entered upon his maturity. (17-18)

This development of the individual is often crafted to be a microcosm of the development of a nation, or humanity as a whole (Weintraub). The bildungsroman, as Buckley describes it, celebrates modern, urban values as more advanced, mature, and liberating than restrictive, provincial values.

Sidonie Smith and Julie Watson have argued that the nineteenth century German bildungsroman had an important "influence on forms of nineteenth-century life narrative and would be a growing significance in the twentieth" where it has become "a decisive model for the presentation of twentieth century lives" $(119,278)$. Elsewhere, Smith uses the specific example of Harriet Martineau's Autobiography to illustrate the way "the fictive pattern of the bildungsroman provides the general structure" for some autobiographies (131). The model, argues Smith, allows Martineau to give "narrative and coherence to her life, locating its meaning in the ideology of the nineteenth century" (132). In Autobiography, Martineau describes her journey away from Christian theology toward scientific rationalism as a journey in which she comes of age. Smith suggests that one of the ways Martineau draws on the bildungsroman is to structure her own 
development as a microcosm of humanity's development: "The evolution of her intellectual development recapitulates the evolutionary progress of humanity (species life) itself, from infancy of mythological beliefs, through its adolescence of metaphysical beliefs, to its maturity of scientific positivism. Her story is the story of civilisation's advancement" (132). Effectively, Martineau uses the form to privilege a narrative of progress which celebrates scientific positivism as more advanced and developed than both theology and metaphysics. Smith is hardly the only scholar to use the bildungsroman model to examine the way authors privilege ideologies in autobiographical coming-ofage stories. Tully Barnett, Helen Buss, Carolyn Heilbrun, Leigh Gilmore and Elizabeth Marshall, Kristi Siegel, and Alex Vernon all use the bildungsroman model to analyse a wide variety of autobiographical coming-of-age stories including war stories, beat autobiographies, contemporary women's life writing, and post-colonial autobiographies.

Although John Barbour does not specifically reference the bildungsroman model, he does explore the way that deconversion narratives can merge with coming-of-age stories. He does this in relation to Victorian literature, particularly Father and Son by Edmund Gosse. Gosse rejects the strict Brethren faith of his father in favour of a vague, more liberal form of Christianity. Barbour suggests that it is one of the first deconversion narratives in which "deconversion is the climax and culmination of ... spiritual struggles, rather than being the first stage of a process leading to the affirmation of new commitments" (74). In other words, Gosse does not celebrate his new found religious commitments at the end of the memoir, but rather ends up in what McClure might categorize as an example of the "ideologically mixed and confusing middle zones of the conventional conversion narrative, zones through which the conventional protagonist 
passes with all possible haste" (4). Barbour maintains that Gosse's new convictions are still evident in the reasons he rejects Brethren faith. According to Barbour, Gosse presents Brethren Christianity as a "failure to live up to the demands and ideals of authentic Christian faith, not those demands, ideals, or faith itself” (79). The kind of Christianity that Gosse ultimately privileges through his indictment of the Brethren faith is "more imaginative, tolerant . . . epitomized by an emphasis on God's love rather than his jealousy and wrath" (80) and most importantly, celebrates "freedom of conscience" (76). This, for Gosse, is "true Christianity" (78). To reach this point, Gosse goes through a number of failed epiphanies "in which the boy's deepest convictions are clarified" (82). His deconversion process coincides with his coming-of-age process. It is no surprise, then, that his rejection of Brethren faith is intertwined with his rejection of his father. Gosse's father becomes the example of what is wrong with Brethren faith, and as a result, the conflicts that Gosse has with his father become representative of the conflicts he has with the religion in general. This parallel, however, goes both ways. The "bullying" in which Gosse's father engages becomes projected on to the entire religion (76). Most importantly, Gosse's departure from his home and rejection of his father's restrictions, an important part of the bildungsroman model, is simultaneously his rejection of Brethren religion. Gosse's father is wrong because he practices the Brethren faith, and the Brethren faith is wrong because of the way his father practices it. Gosse grows up by rejecting both in favour of "true," liberal Protestantism.

The traditional bildungsroman model does have significant limitations, especially for women. In the introduction to their anthology The Voyage In: Fictions of Development, editors Elizabeth Abel, Marianne Hirsh, and Elizabeth Langland 
unequivocally state that "even the broadest definitions of the bildungsroman presuppose a range of social options available only to men" (7). They go on to cite Buckley's definition as a clear example of the gendered nature of the category. This does not mean that bildungsromans or stories of development are irrelevant. In fact, in the early seventies, Ellen Morgan argues that "the female bildungsroman is the most salient form of literature written by women about women" because it expresses "the emergence of women from cultural conditioning into a struggle with institutional forces, their progress toward the goal of full personhood, and the effort to restructure their lives and society according to their own vision of meaning and right living" (185). By the time The Voyage In anthology was released in 1983 , the editors were already wary about this characterization of the genre, qualifying Morgan's celebration by acknowledging that "although the primary assumption underlying the bildungsroman — the evolution of the coherent self — has come under attack in modernist and avant-garde fiction, this assumption remains cogent for women writers who now for the first time find themselves in a world increasingly responsive to their needs" $(13){ }^{20}$ They suggest that there are two primary modes of female bildungsroman: one which closely adapts the model Buckley outlines for women's experience, ${ }^{21}$ the other which features an awakening, where women "grow significantly after fulfilling the fairy-tale expectation that they will marry and live 'happily ever after"' (12). In this latter case, the awakening is often accompanied by an

\footnotetext{
${ }^{20}$ Bonnie Hoover Braendlin argues that the genre is important for ethnic and immigrant women writers for similar reasons (75).

${ }^{21}$ Maureen Ryan suggests a further variation on this in which the female bildungsroman becomes "a tale of compromise and disillusionment" where female protagonists fully recognize and struggle against the limits placed on them by a male dominated world (14). Likewise, Laura Fuderer notes that "individual development and integration into the community" is difficult and often unrealized in female bildungsromans, and that these difficulties "are greatly compounded when the protagonists faces racial prejudice in addition to restrictive gender roles" (4).
} 
affair and the dissolution of the fairy-tale marriage. Despite this, Joanna Frye calls for women to move beyond the bildungsroman and tell stories of development which disrupt linear form and notions of the coherent self (83). Almost thirty years later, Christy Rishoi sees these kinds of narratives from women, where "instead of following the development of a coherent universal subject" they present subjects which are "defiantly specific . . . [and] provisional" (9). Likewise, Smith and Watson note that post-colonial authors adapt the bildungsroman model to reflect a negotiation "at a cultural crossroads of metropole and colony and of conflicting concepts of education and social value" (278). In these adaptations, the lack of a coherent self in a linear development also dismantles the kind of privileging present in traditional bildungsromans. There is no advanced, developed, mature ideology to pit against an antiquated one, but rather two or more conflicting ideologies which must be negotiated.

Not all the adaptations to coming-of-age stories disrupt the privileging present in bildungsromans. Jennifer Silva examines neoliberal coming-of-age stories in which becoming an adult means "learning to 'stand alone' and make choices and decisions independently from a wide range of options" (7). Growing up means to "triumph over one's past by bringing into being an emancipated and independent self' (19). The problem, of course, is that the "wide range of options" is not available to everyone equally; there is an "absence of choice that defines coming-of-age for working-class youth" (8). The result is that these working class youth who have subscribed to the neoliberal coming-of-age narrative feel delayed, or unable to attain the advanced maturity of their middle and upper class peers. The exceptional story of an individual who somehow overcomes a working class childhood to attain an apparently independent 
middle class lifestyle as a result of their superior skills, determination, and decision making, only reinforces the sense that the problem with the working-class that remains working class is that they have not adequately matured to function in the contemporary world. The divide in these narratives, then, is not so much a linear development where an old ideology is deemed antiquated in favour of a new ideology which is represented as more modern. Instead, it is a class divide: the middle and upper classes are represented as having a more mature, advanced skill set with which to make decisions in the contemporary world.

Tully Barnett argues that studying the way contemporary memoirs use bildungsroman models to support and reinforce contemporary ideologies of inequality is important work in the academic sphere. She argues that the academic study of contemporary life narrative seems understandably preoccupied with the experience of the subaltern; the marginalized; the voiceless; and the victimized, traumatized ... This is not only understandable but also vital work in the field. However, its volume comes at the expense of critiques of contemporary conservative memoirs that proliferate largely unexamined. These memoirs or memoirmoments may be boring, trite, infuriating to scholars of life narrative, and trivial given the range of human experiences, expressed elsewhere in the medium of life writing, but they are in many ways stealthy and somewhat sinister in the role they play, in that they confirm and perpetuate the stereotypical views of class politics, and thus they are worthy of attention and analysis. (94) 
Barnett focuses on the way that Michael Dirda and Alberto Manguel celebrate their commitment to reading as a way to climb the class ladder. She argues that, as they grow up, their reading choices noticeably change along with their class status. They end with rather conservative reading choices to match an upper middle class lifestyle. Barnett argues that these memoirs serve three important functions. The first is to reinforce conservative cultural tastes by presenting them as more mature and advanced. The second is to "advance conservative constructions of childhood that locate acts of reading and book appreciation in opposition to, and as a means of escaping, a social class" (94). Like the coming-of-age stories Silva studies, this serves to obscure the class inequality and the absence of choice for working-class youth. The final function is "to solidify the sense of the self as a deserving, faithful, and productive member of the literary establishment" (86). In other words, the authors of these memoirs are able to display a disposition toward reading and their past that confirms their position within the upper middle class literary elite.

Barnes's coming-of-age story, which she tells in two memoirs, uses the bildungsroman model to privilege her new spirituality as more advanced and mature than the Pentecostalism of her childhood, while simultaneously displaying the right spiritual disposition to access the spiritual readers market. Her story seems to hit all of the points of the traditional bildungsroman as Buckley describes it. She grows up in a logging community in Clearwater National Forrest, and it is there that her parents convert to Pentecostalism when she is six. Her father institutes strict rules of behaviour which forbid her from listening to secular music, going to parties with her friends, questioning the behavioural dictates of Pentecostalism, and above all, questioning her father's authority. 
After a brief rebellion in her earlier teens, Barnes finally leaves home and Pentecostalism for good just after graduating from high school. Her aim, she says repeatedly, is to achieve a kind of freedom outside of the rules of Pentecostalism and her father. Even before she leaves, she has several unfulfilling and love affairs. When she leaves home, however, she begins an abusive relationship. It is only after this that she moderates her previous quest for freedom of any rules, finding that she had traded one set of rules for another under the guise of freedom. Instead, she begins her university career and ultimately finds her vocation as a writer. It is in writing, she says, that she can finally learn to submit to something else that restricts her freedom, and where she is able to practice a vague spirituality of her own choosing.

Barnes also draws on several adaptations that female authors have made to the bildungsroman in both fiction and memoir. She presents herself as a woman who, breaking free of restrictive gender roles of Pentecostalism, emerges into the broader, urban world only to find that she faces serious obstacles because of her gender. At the end, however, she is able to overcome these obstacles and find a relationship with a man who supports her career. In part, she points to her education, both at home and outside of the home, as the reason for her success. Like the neoliberal coming-of-age stories that Silva examines, Barnes suggests that it is her superior skill set that enables her to stand independently and make decisions that lead her out of poverty and Pentecostalism simultaneously.

At some points, Barnes also seems to disrupt the conception of herself as a single, coherent person who has developed in a linear way. In these instances, she refers to herself as a separate person in each phase of her life, and she says "each of those girls is 
still with me... I could become one or the other of them again" (Wilderness 170-71). Although Barnes identifies parts of her past as separate selves, they are unified within her; she still has a singular identity that is formed and made-up of these past-selves. Her use of first-person singular throughout both books reinforces this conception of her identity. It is Barnes who grows up in the hollow, converts to Pentecostalism, rebels, leaves home, and begins a love affair with David. This fits clearly with a more traditional bildungsroman coming-of-age story, where there is a linear development of the individual. Even though Barnes worries that her past selves may emerge at any point, she presents her current self as more stable, more desirable, and most importantly, more developed than any of her past selves. In fact, in the closing passages of both books, she laments the fact that she cannot regain the romanticized childhood happiness due to the linear development of time.

More importantly, she uses this linear development to portray her new spirituality as more advanced and mature than that of her childhood and her parents. There is a crucial difference between what Barnes does and the model Barbour creates based on Gosse's memoirs. While Gosse presents the new liberal Christianity as "true" Christianity versus the distorted Christianity of the Plymouth Brethren, Barnes presents Pentecostalism as generally underdeveloped and responsible for stunted growth. Barnes, in rejecting Pentecostalism, is able to develop beyond it. It is not simply her life that develops in a teleological fashion, but religion and spirituality in general. She is able to do this because she presents herself as a coherent individual who has developed in a linear fashion. Her current self is a better, more advanced, and more mature version of her childhood self. Pentecostalism is part of her childhood, and as she grows up, she 
learns how to build on particular aspects of her religious background while rejecting others that hold her back. By contrast, she represents her parents who remain Pentecostals as underdeveloped. Her mother, for example, willingly suppresses her personal development in almost every way, including sexually. Any positive attributes she retains are muted, washed out in the dulling of her "doctrine." Her father maintains his position as the enforcer of the rules which restrict her mother, and by extension, would restrict Barnes. Despite this, Barnes still represents him as having underdeveloped, positive attributes. Barnes celebrates his rational inquiry, and attributes her fondness of it to him. At the same time, she presents herself as possessing a more advanced, modern rationality than her father because she rejects the limits of Pentecostalism. Ultimately, this is how she frames the ecstatic experience of speaking in tongues. In the Pentecostal sphere, it is part of a repressive religious system which she rejects. Outside of that sphere, she celebrates it as the foundation for her writing practice; writing, for her, is the more developed, modern speaking in tongues.

\section{The Full Spectrum of Feminine Colour}

While Barnes critiques a number of aspects of Pentecostalism, her criticism is mostly focused on the strict gender roles. At the beginning of In the Wilderness, she admits that before her family converts the gender roles in her community are already undesirable. While the men who work in the logging communities are "broken by the land's promises and the government's lie" the women are "twice betrayed, first by the land and then by the men who worked it" (15). While their husbands live, they quietly endure neglect and abuse, feigning "sleep when rough hands touch their hips" (50). If 
their husbands should die, women had few options: "find another man to marry or leave" (61). Once the family converts to Pentecostalism, the imbalance increases: "My father's authoritative presence became absolute, my mother's desire to please him even greater. In the teachings of the church, a man's duty is to be the physical and spiritual protector of his wife and children. The woman is to be chaste and modest, subservient to her husband's guidance, lest the mar of her sex tempt her to stray into the ways of the world" (52). The temptation to engage with the "ways of the world" is not restricted to women, especially when they are teens. Both male and female teens need to resist the urge "to go to movies, listen to rock and roll, dance with others. . f feel the sweet exhaustion of gaiety and abandon. .. free of the guilt my every need and movement seemed to bring, the threat of. . . censure, the pall of eternal damnation" (Hungry 8). Females, in the Pentecostalism that Barnes describes, are simply more susceptible to these desires, as Eve demonstrates, and must therefore take their rightful, subservient position in relation to the more spiritually fortified males.

Barnes sees an early example of what happens when women fail to fully accept their role. Although women tend to experience more ecstatic experiences than the men in the church (Wilderness 68), if they become too unruly, they are expelled from the congregation like Lola. When a new pastor, Brother Lang, and his family come to Barnes's church, Lola is one of the few who voices concern (86). Although this is already enough to raise suspicion, Barnes says that it was not this opposition which led Lola to be driven from the church. Lola prays "louder than most men, twirling in the aisle until the long fall of her auburn hair loosened from its bun and flowed around her shoulders ... Even in shapeless skirts and high-necked blouses, there was something unfettered about 
her, something beautiful" (87). Lola simultaneously challenges male authority while sexualizing Pentecostal experience. Barnes says Brother Lang is threatened by her, partly because she challenges his authority, and partly because his "hands tremble to touch her" (90). This desire, suggests Barnes, leads Lang to dream about Lola as a chipmunk that rides his shoulders and turns into a lion each time he tries to remove the animal. He confides in the Barnes family his belief that "God had revealed to him the dream and its meaning: the monster was Lola, full of deceit and cunning ... predatory, destroying the church with false witness" (88). Lang begins to fast and pray that everyone will see Lola for who she really is. The fast lasts several weeks until, finally, everyone in the church agrees to banish Lola. While Lola is still "lovely ... even covered and unadorned" (90), Brother Lang becomes "weak and smug, shriveled to a hard, leathery knot" (89). Barnes says her lesson from this is "be still, be invisible. Do not draw attention to yourself, for in doing so you become a target;" women are "weak, unpredictable, no more capable of controlling [their] whims and desires than Eve" (90). Barnes must suppress any outward expression in favour of quiet subservience to avoid the wrath and punishment of the Pentecostal community, which is led by men.

Barnes's mother provides a model of how to do exactly that. Barnes says her mother's life is "defined by domestic service and silence ... bound by fear of a man's displeasure, his anger and strength" (Hunger 102). She offers a similar description in In the Wilderness, writing that her mother's life was one of "giving and serving in silence" (210). Her mother suppresses her desires, her opinions, and most importantly, her objections to whatever Barnes's father might decide. Barnes says her mother would never contradict him and "risk his disapproval" (91). For example, when he decides to isolate 
himself in the shed and fast until God provides him with direction, Barnes imagines her mother standing by the window, unable to "imagine her husband's body wasted, his broad chest and strong legs gone to bone" as Brother Lang's body had become (110). Though she is concerned for his well-being, she is also worried about herself should he die. Her mother never voices these concerns, forcing Barnes to guess at them. Barnes takes this as further evidence of her subservience borne not only out of obedience to religious principles, but also out of fear. Though Barnes provides no evidence of physical abuse in the memoirs, she fears her father "for all that he did not do but was capable of, as though in the repression of his rage lay the greatest threat of all" (Hungry 188). She imagines her mother struck with the same fear. This fear is made even more potent by the Pentecostal community's response to domestic abuse. Although it "never condoned abuse" the community leaves Barnes with the impression that "it [is] always the woman who [is] responsible for her husband's actions," causing Barnes to wonder what an abused woman "did to deserve her beating" (54). Barnes presents her mother as someone who strives to remain silent and invisible, who suppresses her own desires and dreams in order to fulfil a subservient domestic role, out of fidelity to doctrine and fear of reprisal. Although Barnes at several points shares her mother's fear, and initially sees her mother's life as the only way to be spared the scorn of men, she is ultimately unable to embrace that life. She does not want to be "doomed to life as a woman" (Wilderness 55) or to simply be "the daughter of Eve" (Hungry 188). Instead, she longs to be part of what she sees as the world of men. In Hungry for the World, she describes this using a spatial metaphor. The world of men is "out there" where, as a child, her father works as a lumberjack. It is "where the stories came from. The stories were of danger and survival, 
split-second decisions, moments of courage" (Hungry 23). She is very clear that these are the stories of men, and she says it is "their strength and freedom that I envied" (23). Barnes envies the men because she is relegated to the world of women, inside the house with her mother. She writes that "though it was a good place with its warmth and closeness, smells of fresh bread and fried venison, it was not out there" (23). While inside is the sphere of domestic subservience, outside is the sphere of adventure and freedom. As a young girl, then, Barnes is determined to be like the men, in spite of the admonishment she receives, particularly from her mother: "They would tell me, all the days of my girl's life, that I wanted too much, that it was not my place" (23). Barnes is unwilling to suppress her desires for the life "out there" in order to fulfill her role as a subservient Pentecostal woman.

While, as mentioned earlier, Barnes focuses a great deal on gender differences within Pentecostalism that push women into subservient roles, she also portrays Pentecostalism as encouraging the suppression of desires for both sexes. For example, Barnes suggests that Brother Lang treats Lola so harshly because he is suppressing his own sexual desire. In In the Wilderness, and to a lesser degree Hungry for the World, Barnes uses colour to illustrate the consequences of this suppression: her Pentecostal life with her parents is often associated (negatively) with pale white, while the world outside is full of vibrant colour. Barnes describes the meals she has as a child being "only white: Wonder Bread, mayonnaise instead of mustard, mashed potatoes and cream gravy, white toast dunked in white sugared oatmeal" (Wilderness 160); when the family moves into town, they live in a "white stucco bungalow" (Wilderness 131) where Barnes sleeps under "the whitest sheets" (Wilderness 173). Since the colour white already has strong 
symbolic value within Christianity, it is no surprise that Barnes links it to her faith as well. She imagines "Christ's white robe" (Wilderness 224) and Angels with wings "the cloudiest white" (Wilderness 79). Authority in the church takes on the colour as the "bleached and polished" skulls of trapped animals that anchor "the corners of the preacher's desk, where he [studies] Scripture for next week's sermon" (Wilderness 98). She also describes the two primary religious authorities in her life, Brother Lang (Wilderness 102) and her father (Wilderness 229, 256), as having "pale" skin. Perhaps most potently, however, she carries a "white waxy card" which reminds her of the purity pledge she made, promising not to drink, smoke, dance, or swear (63). By contrast, hippies sport "bright colors" (Wilderness 120), and her adventurous, less religious cousin has "large green eyes, brown hair ... [and] honeyed skin" (Wilderness 154). Even though Luke is the son of Brother Lang, Barnes describes his "startlingly blue eyes" in the same passage where she describes the desire she has for him, desire which leads her to heavy petting that she views as $\sin$ (Wilderness 65). She even uses color to distinguish between the strict rural Pentecostalism of Brother Lang, and the church the family attends when they move in town, which has more relaxed behavioural codes and fewer restrictions on the activities of women, differences her father does not embrace. In this new church, "the choir wore purple robes ... and the light shone through glass stained blue and green" (Wilderness 136). The contrast is brought into focus in a short passage in Hungry for the World where she describes her house: "the silence of the rooms, the impassive eating of the meals, the inert solitude, the moth-colored light-I left the house each morning, gulping air, stunned by the school bus yellow, the lurid sky, the pale pink rise of sun" 
(75). The whiteness of her house and Pentecostalism is filled with a suffocating silence and stasis, while outside is full of fresh variety.

Barnes employs this whiteness when she describes two specific events from her childhood that reveal the way she thinks about the Pentecostalism in general. The first is when she gets her first pair of glasses. Before she wears glasses, she is unable to make out specific shapes and colours. She says they are things "she felt rather than saw," comparing her belief in these distinct colours to her belief in Angels with white wings (79). Likewise, in a later passage, when she tries to make out the image of Jesus hanging on her wall, all she can see is "a small star of light reflecting off the sleeve of Christ's white robe" (Wilderness 224). Once she has her glasses, however, she can see clearly "the colors of grass, the movement of shadows, the ever-changing shade of [her] aunt's hair" (78). Despite what glasses physically do, Barnes associates them with being able to see a variety of distinct colours while she associates life without glasses with whiteness. This distinction becomes important just a short time after she receives her glasses. During a service, Brother Lang tells her that she must give up her glasses as a sign of faith that God will heal her sight. He slips them off her face and tucks "the dark frames into his white shirt" (Wilderness 82). Barnes is not healed, and she spends the next three days stumbling around, unable to see clearly. She tries to pretend, but she is entirely unconvincing. When Brother Lang finally gives the glasses back, both are "embarrassed by [her] failure" (Wilderness 84 ). In order to be a success, Barnes would need to hide her impaired sight better to reinforce the community's belief in divine healing. Although being healed would actually allow her to see colours clearly, Barnes associates this pretending with a suffocating, silent whiteness. 
The second event is her baptism. Baptisms at the church led by Brother Lang are performed in the river. Women wear a "crisp white dress" when they walk into the river for the ceremony. Brother Lang then dips them under the water, and when they rise, "translucent pink showed through the wet cloth. Their skirts floated up like lilies" (Wilderness 67). This brings Barnes anxiety as she prepares for her own baptism: "I was painfully aware of my nipples already rigid from the cold air ... I considered how I would survive the embarrassment of having my wet dress cling to my chest, the shape of my breasts exposed for all to see in that moment before I could cover myself" (117). While the baptismal dresses initially hide the bodies of the women, covering their sexuality in a generic white, the dresses become inadequate once they are wet, as both the contours of their bodies and the colour eventually show through. Instead of the colour being "out there," in this instance, it is inside, poorly hidden and covered. It is no surprise that this is linked to sexuality, and for Barnes, sexual desire. As mentioned earlier, sexuality and sexual desire is something she needs to suppress and hide within the Pentecostal context. In order to be a Pentecostal, she must not only suppress her longing to explore the colourful world "out there," but also the colourful world inside of herself.

For Barnes, women are able to explore and develop the colourful world inside through the use of makeup. This has a direct relationship to the way Barnes portrays her mother. Barnes describes her before the family converts to Pentecostalism as "glamorous ... perfectly composed against the sheets' white backdrop, smooth legs positioned to flatter, as though the world might be watching, judging [her] flat stomach and ruby nails" (Wilderness 47). Likewise, when Barnes sees an older photograph of her mother she finds her "startlingly beautiful ... her lips are colored red or deep pink to match her nails ... 
feminine and vulnerable" (Wilderness 51). Her mother's beauty is directly linked to her makeup. This is even more evident in the contrast to her mother's post-conversion appearance: "her cheeks and lips remained clear, no trace of the paint a ruined woman might wear ... cloaked and colorless, her virtues defined by what she covered and erased rather than what she presented to the world" (Wilderness 52). Ironically, it is her mother's plain, colorless face which Barnes describes as “covered," rather than her mother's face with makeup. This is because Barnes presents the use of makeup as an expression of the true beauty which she must hide as a Pentecostal. As a result, when Barnes begins to break free from Pentecostalism, makeup is one of the first steps. Her grandmother, who sees Barnes's parents' restrictions on Barnes's behaviour as "nonsense" (Wilderness 63), encourages Barnes to "paint her nails" (Wilderness 125). Later, Barnes applies mascara and blush as well: "what I saw in the mirror thrilled me: color, contrast, a face that might draw the attention of young men" (Wilderness 130). This points to the real value of makeup for Barnes: it is a chance to attract men and explore her sexuality. Just as she feels compelled to hide her body after the baptism, she realizes she must "keep [her] twin safe, keep her existence secret ... that other I could become with a few strokes of paint" (Wilderness 130). When Barnes finally leaves home, she no longer hides this other. Freedom from the bland, colourless world of Pentecostal rules for Barnes is the ability to explore her sexuality "out there" in the world, painted in bright colours to match the colourful world. This colourful freedom, however, amounts to exchanging one restrictive gender role for another, only slightly less restrictive one.

Near the end of Hungry for the World, Barnes writes: 
I have come to realize that the will of my beautiful mother, who demanded of herself invisibility, who struggled to suppress her desire for anything beyond the happiness of her family and the good of her faith, may have been the strongest will of all. There are times when I look at her and am struck again by the blue of her eyes: so light, almost white, she would say with regret in her voice, as though the wash of color, like a high-clouded sky, were something to be ashamed of. (238)

Barnes consistently represents her mother as someone who voluntarily stunts her own growth in order to serve others. Her mother sacrifices opportunities, and her own beauty, in order to adhere to the strict rules of Pentecostalism and submit to her husband. Barnes is ultimately unwilling to accept that life, painting it a plain, colorless, pale, white. Instead, she wants to explore the full vibrant colours of the world, and give herself the possibility to blossom and develop her own internal array of colours. Again, this is in contrast to her mother whose blue eyes have faded almost to white due to neglect. While Barnes puts on makeup to attract men and explore her liberated sexuality, Barnes's mother is trapped in the stuffy, silent house where she does everything to please her husband. Barnes attempts to find something redeeming in her mother's experience, but the sentiment falls flat in light of the "regret" in her mother's eyes. Barnes has outgrown her mother.

\section{Sex Outside the Church}

Barnes is hardly alone in casting sexuality as a reason for leaving a Pentecostal church. In fiction by Z. Z. Packer (“Speaking in Tongues”), Lee Smith (Saving Grace) 
and Elizabeth Merrick (Girly), sexual exploration plays a central role in the reasons female protagonists leave Pentecostalism and descriptions of their sexual experiences make up a large portion of the narrative about what happens after they leave. In the case of both fiction (Oranges Are Not the Only Fruit) and memoir (Why Be Happy When You Could Be Normal) by Jeanette Winterson, female protagonists leave Pentecostalism to explore not only sexuality, but also a sexual orientation that their Pentecostal communities reject. The initial results of these departures are not always positive. As the women seek to explore their sexuality in the world outside Pentecostalism, they frequently become involved in relationships that are abusive, exploitative, or simply unhealthy. Such is the case with Barnes.

While Barnes and Brother Lang's son Luke do have several intimate encounters that include some sexual touching, her first experience with sexual intercourse occurs with a high school boyfriend named Tom. Tom is the son of a deacon in the Pentecostal church her family attends in town. In her first memoir, Barnes describes him as "proprietary, jealous beyond reason ... [flying] into rages if he found [her] talking to another boy" (213). During one such rage, he chokes her and cracks her head against the window of his truck. Despite this, Barnes loves him and does not "resist his sexual advances" (214). The sex, however, is an extension of their imbalanced relationship: "I separated myself from his desperate fumbling, numbed myself to whatever pleasure and emotion I might have felt. My only desire lay in pleasing him, in being whatever it was he needed me to be" (214). Barnes goes into more detail about the relationship in her second memoir. At first, her time with Tom seems like the "first taste of true freedom;" she feels "both independent and protected, stronger, and strangely new" (62). The two are 
so enamoured with each other that they become engaged, against the wishes of her parents. The build-up to their sexual encounters is much more pleasant in this telling. Barnes describes a "fire [they] kindled in each other's body" which their commitment to Pentecostal behavioural restrictions cannot smother (63). In order to satisfy their desire, they rent an apartment which they share with another couple, a private getaway so they can spend more time with each other. At one point, Tom describes the promise that the apartment offers: "We can be whoever we want here. We can act however we want ... There are no rules" (66). The apartment is, however, dirty and unappealing to Barnes. Furthermore, Tom begins to create his own rules and "demands that made [her] father's rules seem nearly enlightened" (67). Barnes's disappointment with her sexual encounters with Tom take a sharper focus in the second memoir: "As I lay beneath him I felt nothing of the liberation such space had promised. What I felt instead was disgust" (65). As a result, sex becomes "something other, something more than a shared journey toward physical delight; it [becomes] a coin that I could use to buy back his approval" (67); her role is the "giver" who tries to "reshape [her] desire to more convincingly reflect his," while his role is the taker. Tom ends the relationship in order to see other women.

While Barnes presents her relationship with Tom as abusive and controlling, she presents her relationship with David as horrifying and debilitating. Barnes meets David after she has moved out and is working at a bank. Already she is "tired of the rules" of working at the bank (102). David, like Tom, appears to offer her a chance at freedom. She sees him as her "wise and worthy guide" on her path to "social and spiritual emancipation" (137-38). Her experience with him seems to confirm his position as her liberator since "whatever rules had governed [her in the past fall] away in his presence" 
(134). Unlike the other men she has dated, David does not pressure her to have sex at first. He is content to lay in bed with her and discuss literature. When they finally do have sex, it is "gentle ... gentle for now so that I would learn how much I trust him" (135). She describes David's efforts to win her trust as a seduction; not a romantic seduction, but rather a second kind of seduction which is unclear: "When in it, we don't know where we are headed, what to protest, how to protect ourselves. It's like being led blind down a dark corridor, yet when you stop to push against the walls, they disappear, and you are free. Can't you see? Free" (136). The irony in her description provides an ominous foreshadowing of what is to come. David does "not bring the kind of freedom [she] had anticipated" (172). Instead, he manipulates her trust. David uses her as a sexual toy he shares with his friends, ultimately prostituting her; she becomes "his to take or offer" (163). When she shows reluctance, he punishes her. At first, the punishments are simply emotional ones: he withdraws, ignores her, etc. When, however, she decides to end the relationship, David becomes violent. He ties her up, beats her, and rapes her twice. Once he is finally gone, she begins to recover the parts of herself that had been "disappearing, one room at a time" (194). In fact, she presents her second memoir as one of the final steps in that process.

Barnes places some of the blame for her experiences with David and Tom on her parents and the Pentecostal system they belong to. Her parents insist that the world, out there, is filled with "sex maniacs and pimps" (51) and try to protect her from "that kind of man" (174). They do this primarily by restricting her behaviour: when the girls around her begin to shave their legs and wear make-up, her parents do not allow her to do it; they forbid her from listening to the radio; they do not allow her to go to parties without 
adequate supervision, etc. Barnes's father is the primary gatekeeper of these rules, and her frustration with them fuels her rebellion and her eventual departure from home and Pentecostalism just before her graduation.

Yet, part of her parents' effort to protect Barnes comes from their silence. They do not discuss sex with her, except to say that it is not an appropriate activity for her. Her mother, says Barnes, believes that "there are some things better left unsaid" (174). In the midst of her story of her relationship with David, Barnes wonders "if somewhere in those untold stories [is] a map of experience [she] could follow, some way to believe [she] was not alone in [her] confusion and misjudgments" (174). Instead, when she is a teenager, she relies on her uncle's erotic novels to learn about sex and sexuality. In these novels she reads about "how the rich, spoiled virgin had been kidnapped and held for ransom, how her captors raped her repeatedly and in all ways, how she had hated it at first, then how she came to want it more than anything ... Now she knew some part of herself she had never known before. She understood her truest nature" (47). Barnes has "no one to ask or tell" about what she reads in the books (47). As a result, the books mould her understanding of sex in the outside world. She casually refers back to the books when describing her relationship with David, indicating that her attraction to the "mysteriously charged eroticism" is part of what made her vulnerable to him (104). David is willing to step in and "teach" her where her mother remains silent. In the passage in which she laments not hearing her mother's stories that may have prepared her for David, she describes the way David teaches her how to tie different knots used in S\&M sex play. The passage, and the chapter, ends with a repetition of David's haunting whisper: "Like this . . Like this" (175). It is, ironically, the very attempts her parents make to protect her 
from men like David that propel her toward them and make her vulnerable to them. She is naïve because her parents refuse to teach her about sex and she is rebellious because her parents place behavioural constraints on her that she feels are unfair; when she leaves home, she combines what she learns about sex from erotic novels with what she has been taught about gender roles — most importantly, the pacifying silence of her mother.

Despite the clear objections and fear that her parents have regarding men like David, Barnes frequently equates David to her father, and her own relationship with David to that of her parents. Initially, the comparisons seem inconsequential. David, "like [her] father, is at ease with himself . . believing that there was nothing he could not know and understand, no place in the world he could not walk" (Hungry 128). Her father becomes a trucker once his logging career ends, and he and David discuss trucking (169). The comparison, however, starts to turn dark as David becomes both more manipulative and more abusive. Although David's rules bear "no resemblance to the rules [Barnes is] raised to abide by, they [are] no less absolute" (144). She compares David's punishments to "the discipline and the warnings [she has] heard all [her] life" from her father (194). Barnes describes the relationship as "a house without windows" because she wants "no one to look in and she no longer remember[s] what reason I might have for looking out" (160). This analogy bears a striking resemblance to her description of her life as a girl, trapped inside and longing to get out. Finally, she sees that rejecting her parents, and Pentecostalism, and living with David amounts to "an exchange of one prison for another" (188). David, rather than becoming a guide to freedom from the Pentecostalism of her childhood, becomes an escalation of the worst parts of that Pentecostalism. Barnes indicates as much in her summary of the story of her relationship with David: "it is about 
confusion bred into fear ... It is about being raised to believe that women want to be, must be, dominated. It is about rejecting those beliefs and still being unable to escape them" (153). This inability to escape beliefs about gender roles guides her response to David as much as the erotic novels. She confesses that when she was with David she "still believe[s] what [she has] been taught- that it is the woman who determines the character of the man, feminine virtue that tempers male vice: with our quiet selves we give comfort; with the infinite grave of our suffering, we swallow transgression" (176). She begins to "follow [her] mother's map" in order to pacify David in terms of focusing on housework (189), but also by demonstrating "exaggerated regard, stroking, pacifying, just as [she has] seen [her] mother mollify" (192). Since Barnes links David to her father, she responds by taking on the role of her mother, despite trying so desperately to escape that role.

Barnes's characterization of post deconversion sexual abuse is consistent with the deconversion narratives mentioned earlier. In Packer's story, for example, a young teen named Tia runs away from her aunt and the repressive Pentecostal community her aunt belongs to in search of her mother and the world outside Pentecostalism in Atlanta. The final straw for Tia is when her Sunday school teacher pulls her into a prayer closet and berates her for not taking church seriously enough and for not speaking in tongues. What follows is a scene that is borderline abusive, in which the teacher aggressively "clamp[s] the heels of her hands onto Tia's temples" and prays that she will receive the Holy Ghost (138). When Tia arrives in Atlanta, Dezi, a pimp, befriends her. He lures her to his apartment and sexually assaults her. The assault mirrors the scene in the prayer closet. Dezi's hands "push against her" and he is "pressing and heavy" as she tries to get away 
from him (179). The connection goes even further, as when Dezi pays for her meal at McDonald's before introducing himself, she mistakenly thinks it is God has provided the meal (149). These connections culminate when Marie, one of Dezi's prostitutes, protects Tia from Dezi and tells her to "Run, honey. And don't let nobody lock you in no closet no more" (187). Marie knows about the incident with Tia's Sunday school teacher, but the implication here is that what Dezi has done is an equivalent, and that Tia should not allow either to happen again.

As several critics have pointed out, rape and sexual assault are often central events in the female coming-of-age story. Pin-chia Feng argues that this is one of the many reasons that Buckely's model for the bildungsroman does not suit women, since "sexuality in the female bildungsroman is more often debasing and handicapping than exalting” (7). She then lists numerous examples including Joy Kogawa's Obasan, Gayl Jones's Eva's Man, and Sylvia Plath's The Bell Jar as coming-of-age stories in which women must deal with traumatic sexual experiences as part of their development (7-8, 10). Mary Anne Ferguson goes further in her analysis of rape in female coming-of-age stories. She focuses on Eudora Welty's “At the Landing," Lisa Alther's Kinflicks, and Erica Jong's Fanny. In Welty's story, Jenny's grandfather keeps her captive in order to protect her from her mother's fate: rape, abandonment, and death. When her grandfather's death frees her from his prison, she ventures into town where she is gangraped by a group of fishermen. Ferguson argues that, while the story seems to confirm women's fear that "venturing into the world results in rape" it actually presents Jenny with "a choice between rape and captivity" (233). While Ferguson admits this is an unsavoury choice to say the least, it "also promotes Jenny to the stature of a tragic 
protagonist who must always face such grim alternatives;" Fergusson focusses on Jenny's "freedom to choose" even if it does not lead to a "happily ever after" (233). This freedom propels her beyond the limited roles she is initially offered. In this sense, her grandfather and the fishermen who rape her represent the same sexist system which limits women to one of two restrictive roles: virgin or whore. As Ellen Rose suggests, in women's coming-of-age stories, women often awaken or come of age when they realize that no matter which option they choose, they remain "a commodity prized by men, whose voices blend" (213). This is the realization that Jenny has in Welty's story, the realization that allows her to "go beyond her mother's subsequent captivity and death" (233). She is empowered in a way her mother is not by her ability to choose and her capacity to see herself as equal to men. Ferguson suggests that Alther and Jong push this one step further by introducing the importance of mothers telling these stories to their daughters, and thus interrupting the silence surrounding rape (242; also see Rishoi 26). In this way, the daughters learn about the commodifying roles forced upon them and they inherit some guidance regarding how to resist those roles and cope with the violence they sometimes experience.

This reading of women's coming-of-age stories sheds light on what both Barnes and Packer do in their work. By linking Pentecostalism and Pentecostal authority figures to rapists and sexual assaulters, Barnes and Packer "blend the voices" of the men in order to point to an overarching system of sexism. In Packer's story, her Sunday school teacher's aggressive prayers for her to begin speaking in tongues are the same kind used on "Sisters who refused to obey their husbands" (138). The implication here is that speaking tongues is simply one step on Tia's road to becoming an obedient wife. When 
she rejects that role by running away, Dezi tries to push her into the role of a prostitute. By the end of the story, Tia sees both roles as "closets" which she must resist in order to preserve her own choice. This need to resist both restrictive roles is even clearer in Barnes's work. Although she initially rejects the domesticated, subservient role her mother plays, she finds herself taking it on, first with Tom and later, to a more dramatic degree, with David. Even though she feels at first that she is expressing her own freedom of choice by exploring sexual behaviour expressly forbidden by Pentecostalism and funneled through her father, she soon realizes that David manipulates and restricts that choice. When she finally breaks free of David, she realizes that she must resist the pressure to assume someone else's role for her. Her current relationship illustrates what she has learned: "My husband ... waits for me, porch light on. 'You're home now,' he says. He takes my coat, sits me down at our table. He feeds me good bread, roasted chicken, squash from our garden baked soft and sweet. He locks the doors against the outside, pulls back the sheets and covers me. He tells me to sleep, that he is there, that he means to stay" (235). Barnes's husband takes on the role of the supportive partner, at least in this scenario. He performs housework and he mollifies her. This allows Barnes to pursue her own career-her own identity—instead of moulding her identity to someone else's desires.

Furthermore, Barnes understands that she must pass the information on to her daughter. Although the stories of her relationships with Tom and David are uncomfortable, she does not attempt to hide them or silence them, as her mother does, because without them there would be "nothing to guide [her] own daughter except the silence that is [Barnes's] inheritance" (240). Barnes represents herself as having 
outgrown her mother by recognizing the way that an overarching sexist system pushes her into limited roles and resisting that pressure. She has found a relationship that supports her freedom of choice in terms of both her activities and her identity. Most importantly, unlike her mother, she realizes the importance of talking about her experience and breaking the silence.

Barnes's celebration of these developments, however, comes at the cost of her damning portrayal of her father. Barnes's father is certainly guilty of pushing a submissive gender role on her, and in creating behavioural rules which support that gender role. But Barnes goes beyond this by linking him to David who is manipulative, violent, and abusive. In fact, in some cases, Barnes seems to read her father through her experience with David. Though her father's rules are strict, Barnes hyperbolically calls them "tyrannical" in spite of the fact that her memoir is filled with occasions where her father relaxes behavioural restrictions (e.g. Hungry 69). While he does use spankings as a form of discipline, it is not this physical punishment that scares Barnes the most. In the midst of her relationship with David, she says that what scares her about her father is "all that he did not do but was capable of, as though in the repression of his rage lay the greatest threat of all" (188). Barnes projects this fear of her father's rage onto her mother, whom she presents as “bound by fear of a man's [i.e. her father's] displeasure, his anger and strength" (102). Meanwhile, David actually does what she is afraid her father has the potential to do. Equating David's "prison" to her father's “prison,” David's rage and revenge filled beating and rape with her father's calculated discipline meant to instruct, not only points to a larger system of patriarchy forces women into subservient roles, but also amplifies her father's actions to hyperbolic proportions. 


\section{"Both Reason to Rebel and the Means to Do It"}

Barnes does not portray her father as a one-dimensional villain. Instead, she goes out of her way to present her father in various instances as a pilgrim on a spiritual quest. It is her effort to bridge the gap with her father, the gap she creates when she leaves Pentecostalism and her family home. In fact, Barnes goes so far as to credit her father with teaching her the basics of individual, rational choice. It is this individual, rational choice which becomes the basis of Barnes's future spirituality. Yet, in order to pursue this spirituality, she must leave Pentecostalism. In fact, she represents her current commitment to rational, individual choice as one of the central differences between her current life and her life as a Pentecostal. This seems to present a paradox: though she learned the basics of individual, rational choice as a Pentecostal from her Pentecostal father, her reliance on it is what separates her from her Pentecostal past. She resolves this paradox by presenting herself as having outgrown her father's limited use of that individual rationality. As a result of this growth, she is not only able to realize her own spiritual journey more fully, but she presents herself as better able to understand her father's choices as well.

At a very young age, Barnes's father teaches her that reasoning through questions and problems on her own is important. She writes that her father "encouraged and challenged [her]. 'Look it up,' he would say. 'Find out for yourself'” (Hungry 33). Her father is unwilling simply to provide all the answers to her. He wants her "to use [her] mind" (31). This instruction extends beyond refusing to answer her inquiries. He teases her "with riddles and word games, ask[s her] to tell him which way the wind [is] blowing, 
why it was that Christ insisted upon washing the feet of Simon Peter even though it was his heart that bore the greater stain" (31-32). As the latter example demonstrates, theology was not immune to this rational inquiry. He models this for Barnes in a variety of ways. On one hand, he spends "hours referencing and cross-referencing various texts" (32). Barnes witnesses the manifestation of this contemplative process of reasoning: "I see the inner absorption, the way he is always thinking, thinking in that way that makes him deaf to the kitchen noise and the traffic and the voices of his family, calling him for dinner. He is a traveller, journeying inward, through the maze of his heart and mind and soul" (237). This reasoning, however, is not limited to individual contemplation. Her father also "argue[s] loudly and obstinately with ministers, evangelists, and deacons" (32). The rational working out of theology, Barnes's learns, is both a quiet individualized task and a public testing of ideas. From her father, she learns "the nuance of language, how each phrase could be read and reread, each time different. Words were jewels to be turned and examined for every facet, every fraction of light" (33). They are skills and lessons she continues to value when she leaves Pentecostalism.

Barnes's father also teaches her that there are limits to this rational inquiry. She writes that "even as he insisted that [she] think for [herself], he cautioned [her] against thinking too much. To think was to know, but the desire to know more than had been granted was blasphemy. There were doors that must not be opened, passages that must not be foregone. Satan lurked there, waiting to snag the wayward traveller" (33-34). The specific limits are clearly outlined: "the only absolutes were the legalities of [her] faiththe rules for behaviour and salvation — and my father's authority" (33). Questioning the basic tenants of Pentecostalism or her father's authority, as a result, amounts to be lured 
to hell by Satan. This does not dissuade Barnes from applying the skills of rational inquiry she learns from her father to those two "absolutes." Even before she leaves Pentecostalism she begins to see her father as "a wall of unreasonable denial"

(Wilderness 139). She evaluates her father's restrictions on her behaviour and finds them both "ridiculous" (Hungry 76) and a form of "confinement" (8). Nowhere is this more evident than Barnes's portrayal of the incident that finally prompts her to leave her home and religion behind. On the night of her graduation, her friends are having a party at a cabin without chaperones. Her father forbids her to go. Barnes sees "no reason" in the denial, and as a result, feels "shackled like an animal" (Wilderness 228); while living at home she is "chained by someone else's rules" (233). Barnes evaluates the restrictions of her father and her faith and finds them unreasonable, but because of the restrictions in her home, she is unable to make decisions based on her rational assessment. This is not an isolated incident, but rather a pattern of restrictions placed on her by her father and her religion, restrictions including behaviour as well as political opinions. Barnes notes that she feels her "resistance rise" at the "simple platitudes and condemnations the church hand[s] down" (Hungry 59). These include denunciations of Catholicism, women's rights movements, as well as "fornicators and adulterers and the nearly unmentionable Sodomites" (59). Instead of voicing her objections and arguing with preachers and evangelists as her father does, she keeps "silent, for to question might imply that my allegiance lay with the Enemy" (60). Her fear, in this instance, is not that Satan will lure her to hell, but rather that she will not be accepted by others. Her silence is her attempt to live within restrictions that are not her own, restrictions she does not find rational. 
By contrast, when she leaves home and Pentecostalism she feels liberated to make her own rational decisions. After her initial decision to go to the graduation party she feels "air and space, room to move and breathe" (Wilderness 233); she says "I was free now, more free than I had ever been" (Hungry 82). The freedom she feels to make her own rational decisions is only moderated by her "ignorance, [her] uneasy acquaintance with the world" (82). This ignorance, she says, is what ultimately leads her to fall prey to David, to make the mistake of giving herself to him. She simply does not know enough to make rational choices at that point. Even so, the pain she suffers in her relationship with David is worth it: "better that I suffer because of the choices I'd made than to have no choices at all" (Hungry 188). She speaks in a similar manner about her developing spirituality. "Whatever faith I had," she says "was mine. I possessed it, I had forged it" (Wilderness 226). She no longer relies on her father's "husbanding eye" to "recognize ... and direct ... [her] ravening curiosity" (Hungry 106). She is free to learn and experiment with whatever she chooses and make rational decisions about what she will incorporate into her spirituality. Much of her experimenting comes from her reading, which includes Portnoy's Complaint (104), Harlequin paperbacks (105), books on "supernatural phenomena" (119), books on Inuit spirituality (240) or Nez Pearce spiritual practices (Wilderness 257). This is only a small sampling of the books she reads and draws from. Though it is her primary venue for spiritual exploration, reading is not the only venue. She also experiments with Do Shin Kan, a martial art which she appreciates for its "mysticism - the meditation a kind of prayer" (116). Her freedom from the rules of Pentecostalism allows her to construct her own spirituality by drawing on a variety of sources. The predominant emphasis here, however, is her own freedom to choose rather 
than the rationality of the choice; where as she was chained and confined under the Pentecostalism of her father, she is now free. The rules that she rejects as ridiculous she rejects because they limit her freedom.

While she does not represent the Pentecostalism of her father as completely irrational, she portrays it as dramatically less rational than her new fluid spirituality. She does this through blatant intrusions of post-deconversion hindsight. These are especially prevalent in her first memoir, Into the Wilderness. Barnes, as narrator, positions herself as better able to understand her father's religious activities than he is. Barnes says that "what he believes is that it was the Spirit that spoke to him, that it was my mother's faith and prayers" that leads him to Pentecostalism (256), but Barnes cannot accept that answer:

I can only guess at what drew my normally shy father to the small group of Pentecostal worshipers who gathered several times a week to praise God in loud voices and denounce the ways of the world. Was he intrigued by the unequivocal dictates of religion? Given his life - the seemingly haphazard set of circumstances and catastrophes that had beset his family — the sterile reasoning of an all-knowing God negated the need to question. What a comfort it must have seemed for a man and his family come to the wilderness. $(50-51)^{22}$

The condescension in this passage is palpable. She portrays her father's conversion to Pentecostalism as that of a desperate man seeking simple answers. He willingly gives up his rational choice in exchange for "sterile reasoning" and "comfort." Barnes repeats this

\footnotetext{
${ }^{22}$ See similar passage in Hungry 29-30.
} 
reinterpretation of her father's spiritual activities throughout both memoirs. As in this passage, she frames her appraisals as questions. This allows her, at the end of In the Wilderness to claim that she resists the urge "to intellectualize [her] parents' quest for a new life" (256). This claim falls flat given that her speculation about her father's activities leaves few other options. She presents him as a man who makes a flawed decision to sacrifice his individual rational choice, a decision he himself does not even understand. In fact, his ability to make a rational choice is clouded by "the haphazard set of circumstances and catastrophes" of his life. Barnes, on the other hand, is able to understand his decision because she interprets his life and faith from the position of liberated rationality.

\section{Writing in Tongues}

Rational inquiry is not the only thing that Barnes takes from her childhood and advances beyond her parents. She does the same with speaking in tongues. In her essay, “Prayer, Piety, Passion, and Prose," Barnes makes a striking comparison between speaking in tongues and writing. Of course, there is a long history of writers indulging in descriptions of their craft as an ecstatic experience. Barnes, however, must negotiate between the carnivalesque descriptions of an experience that is part of a religion she is rejecting and the personalized, rationalized, private spiritual quest she uses speaking in tongues to describe. As with rational inquiry, she does this using the coming-of-age narrative: writing is a more advanced, mature, rational form of speaking in tongues.

Although Barnes says that she wanted to avoid the "Western grotesque" in her portrayal of Pentecostal ecstatic experience, she does not entirely escape the 
characterization. Her descriptions of the ecstatic practices in services are reminiscent of those Mencken wrote in the 1920s: "Women [dance] in the aisles, their hair set loose and flowing [while] men [weep] without shame" (Hungry 35). They "shudder beneath the preacher's hand" and then "fall and writhe" on the floor (Hungry 35). When the congregation begins to speak in tongues, "the prayers rose higher, a loud thrum of joined voices, yet each voice distinct and recognizable: Brother Story's b's and p's popped form his lips in little explosions; his wife's language was a monotone string of m's, ah's, and e's, sustained, it seemed, without ever taking a breath. The combined chant surrounded me like the amplified murmurings of bees" (Wilderness 82). The scene intensifies when a visiting preacher or evangelist comes to the church, bringing "an air of excitement, the anticipation of a circus or carnival" (Wilderness 67). The carnivalesque scene that Barnes describes emphasizes the chaotic, emotional release, which reduces individuality to different, unintelligible syllables in a chorus of drones.

When Barnes talks about her own experience speaking in tongues, the loss of individual choice is intensified. It happens "at the end of hours at the altar, hoarse from calling on the Lord, exhausted and nearly incoherent" (Wilderness 118). She kneels "at the carpeted altar, crying, praying until I lay prone in front of the preacher" (Wilderness 204). This is when she begins to speak the "guttural, the hard sounds low and deep in my throat" (Wilderness 118-19). She describes it as something that controls her body and soul (119), leaving her "incapable of choice" (204). While the descriptions of the ecstatic experiences are not exactly humorous, they do maintain a certain "barbaric grotesquerie" which compliments the coming-of-age aspect of her memoirs. As seen in Jesus Camp, speaking in tongues at the altar becomes the ultimate example of the way that 
Pentecostalism demands her to give up her individual rational choice, not only to God, but also to the male authorities of the church. Speaking in tongues is not a private interaction with God in Barnes's memoirs, but rather it is a site of collective emotional release in which a mass submits to an authority figure.

Barnes begins to reinterpret speaking in tongues at the end of Into the Wilderness by separating it from Pentecostal theology. As she stands by the river where she fished as a child, she wonders "what was it that sometimes swept over me, knocked me down to the floor and caused me to sing out in another voice? Even now, if I close my eyes and listen hard enough, the rhythms come back to me, the surge and lilt of vowels and consonants: glossolalia — 'an ecstatic utterance'” (257). Just as she dismisses the theological explanations of her father's conversion, she dismisses the Pentecostal explanation for speaking in tongues and being slain in the spirit: that it is the Holy Spirit that "sweeps" over her. She goes on to break down glossolalia into basic parts of language: rhythms, vowels, and consonants. The description still focuses on the sounds, but they are already much more palatable, almost musical, compared to the buzzing, exploding sounds of her former church. In the very next sentence, part of the same paragraph, she makes an implicit comparison to Native American practices: "In the woods above our canyon, Nez Perce once went alone to fast and pray, to have their visions. There are times I long to search out their weyakins, their sacred places, to hear the dry rattle of snakes and feel the bloodletting vines of berries, to be purged, to dream in the tongues of animals" (257). Even though she does not explicitly equate the two traditions, the implication is that the ecstatic experiences of Pentecostals are at least similar to those of the Nez Perce. On the page, italicizing both "glossolalia" and 
"weyakins" makes this evident. On the larger scale, Barnes's description of the Nez Perce practices hails back to her own father's period of fasting and prayer in an effort to determine God's will, just before the family leaves the logging community. Free of Pentecostal theology, Barnes represents herself as able to see patterns across a variety of religious traditions. This ability points not only to her own pluralism, but it also demonstrates how she can appreciate speaking in tongues without accepting Pentecostal theology. This appreciation, however, only goes so far. Though she may "long" for these ecstatic experiences in a variety of religious traditions, she does not indulge in them. Instead, she stands by the river listening, remembering, and imagining.

Barnes's reinterpretation of speaking in tongues goes one step further in her essay "Prayer, Piety, Passion, and Prose." In that essay, she describes spending "hours on [her] knees, hands raised to Heaven, questing not for salvation, for that had been granted, but for the Spirit to possess [her], for the gift of glossolalia, speaking in tongues" (7). Interestingly, Barnes does not describe her experience of actually speaking in tongues. Instead, she focusses on her experience as an example of "questing," which she celebrates throughout the essay. She then equates that experience to writing:

I have to tell you that writing is not much different. It feels like a calling to me, something that I am simply meant to do; it fills me with a novitiate's modest pleasure; it requires of me submission; it brings me to my knees. And when whatever it is that happens happens, when the Muse makes her visit, when the Creative Impulse takes hold, it feels like nothing so much as that infusion of passion I felt at the altar. And why should I think there would be a difference? I believe in this act of writing with a familiar 
conviction, and I cannot help but be grateful for having learned the elements of faith early on, for being able to recognize and adhere to the rituals of the quest: devotion, desire, humility, belief -all embodied in the mundane tasks of waiting, watching, listening for hours, days, perhaps a lifetime. (7)

Barnes's comparison of speaking in tongues and writing begins by describing how they both feel; both provide a sense of vocation as well as pleasure. Once again, Barnes draws upon other religious traditions in her description, albeit less specifically this time. The pleasure Barnes feels is like that of a "novitiate," a role used in several monastic traditions, but not Pentecostalism. Though she compares writing and speaking in tongues on the surface, Barnes also defines a larger category of questing to which both speaking in tongues and writing belong. Later she elaborates on this questing by identifying the "elements of faith" and the "rituals of the quest." Here, perhaps more than any other place in her writing, she homogenizes religious experience. For Barnes, all faith and questing requires "devotion, desire, humility, [and] belief." The Protestant legacy echoes throughout her description, especially when she says that these elements are "embodied in ... mundane tasks." The mundane tasks of "waiting, watching, and listening" are framed as "submission." For Barnes, spiritual quests, like speaking in tongues and writing, require submission. This submission raises some questions about her earlier privileging of individual, rational choice. If she is "submitting," is she giving up her individual, rational choice? This is even more problematic in the sentences that follow. "Something" takes hold of her. She offers names for this "something": "the Muse" or "Creative Impulse." The interchangeability of these names indicates that the 
nomenclature is not what is important. What is important is the "passion" the "something" brings with her, which is very similar to the passion she feels at the Pentecostal altar. As a result, the "something" that grabs hold of her while she is writing is linked to the "something" that "sweeps over" her in Pentecostal services. In both experiences, she must submit to the "something." Unlike the passage at the end of Into the Wilderness, however, Barnes does not stand at a distance contemplating spiritual practice. She is a writer and she describes this submission as part of her practice.

The rest of the essay, as well as the memoirs, provide a context for differentiating the submission required for writing and that required for speaking in tongues in a Pentecostal context. The essay as a whole is about writing as an "individual quest for meaning, identity, and salvation in its various, often surprising forms ... Who am I, and why? These are the questions that define the speakers in poetry, the characters in fiction - the questions that writers of personal nonfiction must ask of themselves" (2). Identity, meaning, and salvation are, therefore, things one can achieve individually, through writing. The greatest obstacle writing individuals face in this quest is not discovering the illusive meaning, since "the quest is not a quest for absolute meaning but a journey toward a narrative that can somehow contain and arrange the puzzle pieces of our lives" (4). Instead, it is the restrictions of others. The narrative that writers individually create does not always match that of their "family and community," and as a result writers must "break the codes of conduct, the codes of silence and submission" and "risk being cast out and stripped of membership in the tribe" (3-4). Barnes goes even further to suggest, rather surprisingly, that "mainstream American culture in general is not tolerant of the quest [because] it takes time and lacks defined direction. It refuses to 
adhere to the dichotomies and emphasizes instead the individual's ability to forge for him or herself a particular story of meaning" (4). Despite what Barnes says here, she actually sets up a dichotomy of her own. On one hand is family, communities, and mainstream American culture, which require silence and submission to codes of conduct. Although she does not explicitly say so, this is the kind of submission she repeatedly represents as required for participants in Pentecostal communities: silent submission to authority. On the other hand is the quest for meaning, enacted through writing, which celebrates the individual. The submission here simply requires the individual to submit to the quest itself. Individuals must commit to spending time to working on the quest while at the same time risking expulsion from a larger group. Since individuals create their own meaning, narratives, and ultimately, the customized guidelines of their own individual quests, this is essentially the submission of the individual to the individual.

Barnes reinforces this understanding of writing, and literature in general, throughout her memoirs. As a child, books provide a "connection to the outside world" (Hungry 33). When she reads books as a child, she says "their pages soften ... the silence" (58). Though she does not define this "silence" in this context, it has clear echoes to the "silence" she associates with Pentecostalism, specifically the role of women within the religion. Books provide some resistance. She reiterates this resistance when she explains that, unbeknownst to her parents, her teacher asks her to screen books for the class library (58). Barnes covertly reads controversial books that show her the world outside that her father's Pentecostalism labels as off limits. She is particularly fascinated by the "mysticism" of "Nostradamus and Black Elk, Philippine faith healers, African fire walkers, Uri Geller ... but this was witchcraft, so [she hides] the books in the folds of 
[her] sweaters" (59). Not only do these books expose her to a variety of religious and spiritual practices, which she homogenizes as "mysticism," they do so in explicit opposition to her father's Pentecostalism. Books, for Barnes, are a site of her individual resistance. After she leaves Pentecostalism and survives her relationship with David, the study of books at college presents a path "into a larger world [she] ha[s] always longed for" (Hungry 225). It is in this college setting that she begins her writing career, encouraged by a creative writing professor. In writing, she finds a way to "rediscover that lost part of [herself]" (231). As mentioned earlier, this is ultimately how she frames both memoirs: an individual quest of self-discovery. What allows her to succeed, to a certain degree in this quest, is her superior skill set, her commitment to rational, individual choice, and by extension, her rejection of Pentecostalism.

\section{Conclusion}

In her book on the memoir boom in North America during the late 1990s and early 2000s, Julie Rak says memoirs are "a way to construct, package, and market identity so that other people will buy it" (7). One way of doing this is by appealing to a particular market of readers, like the market of spirituality readers. This means displaying the proper spiritual disposition that values religion that is not only complimentary with liberal values like individualism, freedom, democracy, and intellectual inquiry, but that also serves to raise an individual's self-value without requiring significant investment or commitment. As a result, it devalues religions that do not seem to meet these criteria. Barnes uses elements of the bildungsroman model to display this spiritual disposition. She casts Pentecostalism as restrictive and antiquated, and those who practice it (namely 
her parents), stunted in their growth as independent, self-valuing individuals. It is her individual strength and determination which allow her to break free from these restrictions and grow up as a rational individual who makes decisions about religion and spirituality based on the proper criteria.

Barnes is hardly the only author who uses bildungsroman techniques to frame a departure from Pentecostalism. Christine Rosen, Donna Johnson, and Diane Wilson have all written recent memoirs which use a similar frame. Sheri Reynolds, Lee Smith, Kelly Kerney, Z. Z. Packer, and Elizabeth Merrick have all used the frame for fictionalized stories of leaving Pentecostalism. Outside of the United States, UK authors Jeanette Winterson and Tim Parks have both used the frame in autobiographical novels and memoirs, while in Canada, Billie Livingston and Rae Spoon use it in fiction. While not all of these authors found success with the spiritual reading market, Barnes seems to have found some. Her first memoir was a Pulitzer Prize finalist in 1997. It led to publishing contracts for her next memoir and helped her secure a permanent position as a creative writing professor at the University of Idaho.

This does not mean that Barnes constructed a memoir with the sole purpose of achieving success in the marketplace and securing future employment and publishing contracts. As Rak suggests, "memoirs turn identities into commodities that we buy or borrow or even steal, but they also participate in the manufacture of public identities as a reader encounters the life of another within the context of his or her own experience, values, and beliefs about what it means to be a person. Both things are true of the production of memoir, and they do not exist without each other" (7). In other words, by celebrating her spirituality at the expense of Pentecostalism, Barnes not only gains access 
to a market to sell books, but she also helps support the belief that her spirituality is, in fact, more advanced, more liberating than Pentecostalism.

Perhaps more than any other author listed above who draw on the bildungsroman model to frame a deconversion narrative, Barnes presents a sympathetic portrayal of Pentecostal practitioners in the form of her parents. They are not evil, manipulative characters, or purely naïve and helpless. Instead, they are people who made decisions that Barnes tries to rationalize, decisions that ultimately stunted their growth as individuals. The result is that Barnes pities her parents because they were not able to overcome the limits that Pentecostalism placed on them. This pity is almost more insidious, or as Barnett might suggest, "stealthy and somewhat sinister" than the obvious caricatures of Pentecostals (94). It naturalizes the idea that liberal spirituality is the religion of rational, independent, and mature individuals, while Pentecostalism is the religion of individuals who do not have the inherent skill set to fully realize their potential as individuals. 


\section{Chapter Three}

\section{She May Be Hot, but She is Also Really Crazy: Celebrity Pentecostal Deconversion Narratives}

In a 2013 interview with Stephen Marche for Esquire magazine, actress Megan

Fox talks more openly about her religious upbringing than ever before. She specifies that she was raised as a Pentecostal and that she spoke in tongues, a form of ecstatic speech practiced by a growing number of charismatic evangelical Christians. Rather than framing the experience as part of her sheltered childhood, Fox expresses nostalgia when she recalls speaking in tongues. She admits that her description of the experience makes her "sound like such a lunatic" (65), but this self-conscious acknowledgement did little to alter the subsequent coverage of her statements. "Megan Fox May be Hot, but She is Also Really Crazy" read a headline from the CBS Detroit website. The headline was unusual for much of the follow up coverage in the standard press, which simply pulled quotes from the interview with Esquire and provided minimal context. The sentiment was, however, typical of editorial pieces and articles in gossip magazines and websites, which call her "crazy" (Emery; Jane), "weird” (Kiefer), and "insane" (Gawker).

There is a dramatic contrast in the way these same gossip magazines and websites wrote about pop star Katy Perry after her similar revelation in an interview with Vanessa Grigoriadis for Rolling Stone magazine in 2010, just three years earlier. Like Fox, Perry was raised as a Pentecostal, and faced similar behavioural restrictions. Perry rebelled against those restrictions and it had a direct impact on her evolution as a pop star and celebrity, again, very similar to Fox. Both women publicly support gay rights and are pro-choice, and they contrast those political positions with their religious upbringing. 
However, where Fox talks about her own experience speaking in tongues with a certain nostalgia, focusing on how it feels, Perry firmly positions it as something her parents do, something she can appreciate as one spiritual practice among many equally acceptable practices, but something she no longer does and has no desire to do.

In essence, Perry demonstrates the "right" spiritual disposition toward her Pentecostal past and her parents, who act as a stand in for that past. She adapts the coming-of-age as deconversion narrative that Barnes uses for a short, punchy article that appeals to a popular culture audience and develops her value as a celebrity. Fox, on the other hand, demonstrates a spiritual disposition that is just different enough for her to be labelled as crazy. To some degree, however, this disposition also lends Fox a certain level of mystery or intrigue. She is careful to express longing for the ecstatic experience rather than for the more conservative elements, either theological or political, of her Pentecostal past. As a result, she raises her value as a celebrity, though in a very different way than Perry. Both ways of talking about a Pentecostal past, however, help reinforce the boundary between what Orsi calls "good" and "bad" religion, and strengthen a hierarchy which situates neoliberal spirituality as normal compared to Pentecostalism.

Examining the way celebrities use their deconversion narratives to raise their own values provides several valuable insights. First, it illustrates how pervasive deconversion narratives, especially coming-of-age deconversion narratives, have become. These types of narratives are not regulated to extended memoirs, but they appear in promotional interviews as an accepted way of raising a celebrity's profile and value. Second, it helps pinpoint the line between "good" and "bad" religion in broader American culture. Finally, it provides a frame of reference for examining the way authors promote 
themselves in interviews. The contexts and target audiences are very different for authors than for celebrities like Katy Perry and Megan Fox. Nonetheless, the strategies they use are similar. Like pop stars, authors aim to establish an affective relationship with their audience by displaying the right spiritual disposition toward their religious past, a disposition which firmly places them on the right side of the line between "good" and "bad" religion.

\section{Spiritual Competence and Celebrity Studies}

In this study, I draw on scholarly work that examines celebrities themselves as commodities, not merely producers and promoters of commodities. Graeme Turner sums this up well: “'the celebrity-commodity' can be manufactured, marketed and traded—and not only by the promotions, publicity and media industries — and so it can repay investment, development, strategic planning and product diversification" ("Approaching” 14; also see Dyer 5). Elsewhere, Turner rather bluntly states that "celebrities are developed to make money. Their names and images are used to market [various products] ... Media entrepreneurs want celebrities involved with their products because they believe it will help them attract audiences" (36). P. David Marshall, who was instrumental in developing this approach to celebrities as commodities, uses Oprah as an example: Oprah has developed an "intimate connection to a loyal home and studio audience." That connection allows Oprah to be sold "as a commodity for the selling of other advertised commodities" (135). The value of celebrity-commodities, then, is their ability to share their affective relationship with an audience with another commodity (in some cases, even another celebrity-commodity), ideally appreciating the value of both 
commodities. While Oprah developed her celebrity-commodity value primarily through her daytime talk show, she, like other celebrities, often uses multiple venues to bolster her value. As Marshall argues, celebrity-commodities gain value through "their primary art form — as actors, musicians, singers, athletes - as well as the extra-textual dimensions of interviews, advertisements/commercial endorsements, award nights and premieres" ("The Promotion" 39). For example, a film actor's value as a commodity may have little to do with his acting ability and more to do with his photo shoots in magazines, his revealing interviews on late night talk shows, his frequent appearances in tabloid newspapers, and the internet memes circulated using his image. What is important is not his skill as an actor, but the connection he has with an audience.

Developing this connection with an audience is rarely the sole responsibility (or achievement) of the celebrity alone. As Turner suggests, "the development of a celebrity's public profile ... is a serious business and ... it is usually placed in the hands of a third party" or more accurately, parties (Understanding 37). While the development may begin with a celebrity collaborating with a manager, that manger often consults with a team of public relations assistants. As a celebrity grows in popularity, the number of interested parties grows as well. As Turner suggests, celebrities "are a financial asset to those who stand to gain from their commercialisation—networks, music production companies, agents, managers, and finally the celebrities themselves" (Understanding 37). Each of these interested parties may have an influence on the way the celebritycommodity is developed (i.e. the construction of a celebrity persona, how that persona interacts with an audience, etc.). In addition to these behind the scenes interests, journalists and interviewers have a role to play in the development of a celebrity- 
commodity. For example, Stephen Marche contributes to the Megan Fox commodity in the questions he asks, the quotes he chooses from the interview, and the way he presents her in the final written piece. His interest in increasing his value as a writer/journalist, as a result, impacts Fox's commodity value. By extension, the gossip press also influences the way a celebrity-commodity is developed by commenting on the celebrity's activities and circulating behind the scenes images and stories, which may or may not be "true." Finally, fans and critics who discuss celebrities online expand the "unregulated communication" surrounding celebrities, which also impacts their commodity value (Rojek Fame Attack 133). Ideally, all the various interests work in harmony to produce a celebrity-commodity from which all interested parties can profit. More often, however, the celebrity-commodity is caught in a "web of conflicting interests" (Turner Understanding 38). The result is an ever-fluctuating image and narrative surrounding the celebrity-commodity, which is altered by official corrections and subversive counter images. It may seem that the celebrity loses agency in all of this, but that is not necessarily the case. It is sometimes difficult to parse out which part of the collaboration a celebrity is responsible for, with the exception of cases when the celebrity may go off script. Nonetheless, the celebrities themselves do have agency in the creation of their public persona and the development of their image as a commodity, but it is an agency that is embedded in and dependent on the celebrity marketplace and various conflicting interests of its participants.

One way for celebrities to develop a positive affective relationship with an audience is to make the audience feel as though the celebrity is like them — part of the same group and community. Chris Rojek explains that "by virtue of their appearance, 
mannerisms and public statements, the celebrity expresses brotherhood with structurally specific emotional preferences, cultural values and lifestyle predicaments. This may take the form of knowing asides, tactful observations, jokes or political statements that the celebrity uses to establish a rapport with the viewers" (Fame Attack 131). This rapport allows the audience to have "the impression of friendship, shared understanding, common ground, and other features of reciprocity between the celebrity icon and the audience. In this way, the audience is encouraged to 'know' the celebrity without ever physically meeting them" (133). This rapport building often happens in the form of celebrity confessions on talk shows, one-on-one interviews, or autobiographies. Anna Nunn and Anita Biressi suggest that in these confessions "the celebrity figure reveals to the public the 'story' of their misery, their flaws and their roots in a previously private or early life. A contract seems to be negotiated in which 'authentic' or 'truthful' personal disclosure is traded for continuation of the relationship between the celebrity and his/her followers" (50; also see Marshall "Promotion" 37). Even when the celebrities themselves do not perform the initial revelation, it can have a similar effect. Joke Hermes draws on his field research to suggest that one of the attractions of celebrity gossip magazines, and celebrity gossip in general, is that it allows audiences to feel as if they have a close relationships with celebrities because they find out what was initially private details about the lives of the celebrities; celebrity gossip allows an audience "to feel involved with the stars and celebrities ... [and to feel] the pleasure of extending [their] family by including the stars" (295). Of course, if the revelations that gossip magazines and columnists publish gain traction through circulation, they often prompt a confession from the celebrity either confirming or refuting the gossip. Either way, a celebrity's response to 
gossip offers an audience a chance to see what the celebrity presents as the "authentic, true" story, hopefully strengthening the affective relationship with the audience and raising the value of the celebrity commodity.

Celebrities must do more than reveal details to develop this para-social fraternization with an audience. While revealing these details, they must also perform the right feelings in a convincing way. Nunn and Biressi draw on the work of Arlie Hochschild and Eva Illouz to describe this performance of feelings. Hochschild suggests that, in various social situations, there are "feeling rules [which] define what we imagine we should and shouldn't feel and would like to feel over a range of circumstances" (82). She goes on to suggest that "rules for managing feelings are implicit in any ideological stance" and that "when an individual changes an ideological stance, he or she drops the old rules and assumes new ones for reacting to situations" (99). While Hochschild focuses on how individuals internalize these rules, Nunn and Biressi examine the way celebrities capitalize on rules (and accompanying ideologies) that their audience has internalized by performing the right feelings, thereby demonstrating that they share an ideology with their audience (50). More often than not, celebrities embed these performances in a therapeutic, coming-of-age narrative that they reveal in a confession.

Illouz examines the rise of these therapeutic narratives, the feeling rules they tend to incorporate, and the ideologies embedded within them. She suggests that these narratives frame the past as a source of psychic suffering that the individual must manage and strive to overcome in order to achieve emotional freedom and realize his/her true self (54). At the most basic level, when someone identifies elements of the past as obstacles to individuals realizing themselves as emotionally stable it reveals a certain ideology. 
More than this, however, Illouz argues that the form of a therapeutic narrative itself is a kind of capital that carries additional ideological assumptions. Using the therapeutic narrative to talk about feelings demonstrates what Illouz calls an "emotional competence," meaning that individuals are able to "deploy a common cultural structure to make sense of their difficult emotions and put them 'to work' by eliciting a narrative of suffering and self-help, which they can in turn ... share and capitalize on to further their intimacy" with other people (69). Celebrity versions of these therapeutic narratives identify something in the past, often childhood, as "that which prevents the individual from being successful, fulfilled, happy, or intimate despite all appearances of a triumphant life" (Nunn and Biressi 50). The celebrity confession, as a result, reveals that the celebrity struggles with their past in spite of their success, just as members of the audience struggle with their pasts. In addition to this, framing these struggles according to a recognizable therapeutic narrative enables the audience to understand and relate to the struggles of celebrities, while recognizing the celebrity as someone who is emotionally competent. Finally, identifying the obstacles on the path to success and demonstrating the appropriate emotions in response to those obstacles supports a particular ideology about what is an obstacle, what is appropriate, and whose responsibility it is to overcome the obstacles (i.e. the individual).

Although Verter mentions neither feeling rules nor celebrities, his understanding of the way displaying the proper spiritual disposition gains one spiritual capital bears an important relationship to celebrity confessionals and the affective relationships they help develop between celebrities and their audiences. Just as celebrities must display emotional competence in their reactions to obstacles and the way they frame their 
narratives in order to appeal to particular audiences, they must also display spiritual competence in their emotional responses to their religious past and in the ways they frame their deconversion stories. Celebrities must demonstrate the right spiritual disposition toward religion and spirituality through a detached familiarity with multiple traditions and an emotional enthusiasm for personal, emotional growth and selfrealization that any religious practice might afford an individual. By extension, celebrities might develop further spiritual capital and emotional attachment with a "spiritual" audience by condemning religious practices that eschew universalism and seem to stunt personal growth.

This is precisely what Katy Perry does in her deconversion narrative. She demonstrates the "proper" spiritual disposition regarding her Pentecostal past and her undefined, neoliberal spirituality. Specifically, she frames her Pentecostal past as a traumatic obstacle which stunted her personal growth as a performer and as a woman, while her current spiritual omnivorosity enables her to cope with the emotional aftermath of this traumatic obstacle and come closer to realizing her "true," emotionally stable self. The content, emotional performance, and narrative framing of her story allows her to strengthen her affective relationship with her audience with various kinds of capital (i.e. emotional and spiritual). It is ultimately the strengthening of this relationship, partly evidenced in the gossip press's reaction, which allows her to appreciate as a celebrity commodity. 


\section{From Angel Eggs to Worshiping the Hamburgler: Katy Perry's Deconversion}

\section{Narrative}

Vanessa Grigoriadis opens her cover story on Katy Perry with an anecdote about how the pop star manages her image through social media. Perry had been Googling herself and discovered that many gossip sites were reporting that she had criticized fellow singer Miley Cyrus for her new look. Perry refuted these rumours by posting a tweet that read "I never said shit about my girl Miley. I love that ho" (40). Grigoriadis celebrates the post for its savviness: "Not only did hundreds of gossip sites report on her tweet, but she had also managed to publicly call the 17-year-old Miley Cyrus a 'ho.' That was naughty. That was walking the line. That was exactly the kind of moment that Perry lives for" (41). Throughout the article, in which Perry details her Pentecostal past in more detail than ever before, Grigoriadis continually points out ways that Perry walks a line. Even when the reporter does not highlight it, Perry seems to strike the right balance in speaking about her deconversion so that she can strengthen the affective bond she has with her audience and thus appreciate her value as a commodity.

The first way that Perry walks this line is through her presentation of a clear before and after narrative of her deconversion from Pentecostalism. The Rolling Stone article establishes this distinction from the very beginning with its subheading: "How did a fire-and-brimstone-preacher's daughter become America's sexiest pop star?" (41). The question implies that a dramatic transformation has taken place, and that the article will describe it. Of course, the story of Perry's transformation, her deconversion narrative, had been developing in the media ever since her first smash single, "I Kissed a Girl," in 2008. The 2010 Rolling Stone interview reiterates this narrative. The article explains that 
Perry's parents banned her from “attending coed parties and dances, didn't sign her up for sex education in school and forbade most pop culture, including magazines, TV and movies in the home" (44). In addition to these prohibitions, which she shares in earlier interviews, Perry adds that she was not allowed to use the word "lucky" because it sounded like "Lucifer," and that her family referred to deviled eggs as "angel eggs." Elsewhere, she bluntly states, "I didn't have a childhood" (qtd. in Robinson 160). Things began to change, she says, as she began to discover the world her parents were hiding from her. First it was secular music, especially Alanis Morissette. Then, when she finally left her home and faith behind, she says "I began to become a sponge for all that I had missed — the music, the movies ... Meeting gay people, or Jewish people, and realizing that they were fine was a big part of it" (qtd. in Grigoriadis 45). Of course, this exposure had an impact on Perry's politics. While she "grew up with Fox News at home every day" she now describes herself as a "CNN girl" who openly supports President Obama and gay rights (qtd. in Scaggs 30). Perry's transformation is punctuated by an unrelated name change. ${ }^{23}$ All of these before/after distinctions point to the fact that Perry has changed. She is no longer the conservative Christian girl she used to be, or at least appeared to be.

Perry balances this division between past and present in two ways. The first is consistent with deconversion narratives in general. She represents herself as someone who did not quite fit in to the conservative Pentecostal community, as someone who needed to leave in order to realize her dreams and, ultimately, her "true self." The

\footnotetext{
${ }^{23}$ Born Katheryn Hudson, she changed her stage name to Perry to avoid confusion with actress Kate Hudson. A New York Post article, which came out less than a week after the Rolling Stone article, uses the name change as a frame to represent how drastic Perry's transformation has been (Cohen).
} 
celebration of Perry realizing her "true self" partly undermines the sharp division between her Pentecostal past and her present, but in a way that packages her deconversion as a therapeutic coming of age narrative, where Pentecostalism is the obstacle she must overcome to achieve professional and, more importantly, personal success. There are two complementary plotlines that help characterize Perry's Pentecostal childhood as stifling her development. The first is her characterization of herself as "Christian but modern" (qtd. in Grigoriadis 45). In an earlier article in Cosmopolitan, Perry explains that she "never took part in the rules and hatred that sometimes go along with religion" (qtd. in Halperin 30). This "modernness" made Perry the odd one out in her Pentecostal environment, which failed to cultivate her intellectual development. In the biopic Part of Me, an 18-year-old Perry tells the camera that "I feel like I was never even allowed to think for myself, and having any kind of feminist, live on your own, independent spirit is just of the devil" (Katy Perry). It is only once she moves out and leaves Pentecostalism behind that she was able to explore a broader world of religious and sexual practices. This exposure is what helps her quickly develop her neoliberal spirituality, and helps her become a pop star.

Perry's desire to become a pop star is the second plotline weaved together with her stunted intellectual growth as a child. In fact, Grigoriadis mentions this desire right after quoting Perry on her modern Christianity that was out of place in Pentecostalism (44). Her desire to become a pop star is equally out of place. While her parents supported her career as a gospel singer, they prohibited her from listening to "secular" music, which might help her develop as a pop star. What enables her to begin this development is her exposure to artists like Alanis Morissette, Freddie Mercury, and Madonna. After Perry 
discovered this music, "she started to write songs about love—and boys—on her guitar" (45). Grigoriadis, along with several other writers and Perry's biopic, position this moment of thematic change in Perry's writing as the beginning of her career as a pop star. Just as Pentecostalism is an obstacle in her personal development, it is also an obstacle in her becoming a pop star. This does not mean it was easy for Perry. Part of Me positions her Pentecostal childhood as the first of several obstacles she must overcome to make her "childhood dream come true." Nonetheless, it is still the first obstacle. As a result, the clear division between Perry's Pentecostal past and her present becomes not a division of altered identities or even ideological beliefs, but rather one of life with an obstacle and life once the obstacle is overcome.

The characterization of Perry's parents as the face of Pentecostalism, especially as an obstacle in her life, supports the packaging of her deconversion as a therapeutic coming-of-age narrative. It helps that Perry's parents have developed a public persona of their own. Keith and Mary Hudson are Pentecostal evangelists who go on speaking tours and sell books. Their activities and their comments, especially after the Rolling Stone interview, have become news stories. For example, when Keith Hudson made vaguely anti-Semitic comments in a church in 2013 , it became news and he publically apologized. More importantly, however, the Rolling Stone interview and follow-up pieces highlight the role Perry's parents played in her religious upbringing. As mentioned before, the article details the household rules that prevented Perry from listening to secular music and eating Lucky Charms. Grigoriadis characterizes these rules as "not only strict but nutty" (44). Perry's discussion of speaking in tongues contributes to this characterization. She begins by saying, "My mom and dad practice 'tongues and interpretation' together- 
my dad speaks in tongues, and my mom interprets it ... That's their gift" (45). It is only later that Perry admits she used to speak in tongues as well, and then she quickly moves on. Standard media outlets only reported that her parents spoke in tongues. Gossip magazines and sites, meanwhile, lambasted Perry's parents, calling them "strict and nutty" (Standora), "really crazy" (Hilton), even "grifters who were incapable of working in the real world, so they used some strange reading of the Bible to make a buck, and they raised their daughter in a really f-cked up way" ("Katy Perry: 'Speaking”"). These articles cast Perry as the gracious victim of an abnormal childhood while her parents are the villains, the ones who created the obstacles she had to overcome to achieve her success. In order to demonstrate that she has not only achieved professional success as a pop star, but also spiritual competence, Perry discusses her openness to various religious and spiritual practices, including those of her past, while confirming her lack of investment in these practices. Perry insists that she is still a Christian even though she adds, "I don't think a lot of people would consider me a Christian" (qtd. in Gunderson "Teenage Dream"). Grigoriadis appears to be one of these people, as she begins the discussion of Perry's current Christianity by writing, "It’s surprising to hear Perry talk about God in this way, because one would think her religious past is behind her" (47). This is, no doubt, partly due to Perry's deconversion narrative, which numerous articles have covered. There is, however, something else that influences this perception: Perry's sexuality. The media has explicitly labeled Perry as a "full-on male fantasy" (Wallace 69) with frequent appearances on lists of the sexiest women that appear in men's magazines. ${ }^{24}$ The photos accompanying the Rolling Stone article help to further this

\footnotetext{
${ }^{24}$ For example, Perry topped Maxim's list in 2010 and Men's Health's list in 2013.
} 
image. In the photos, she appears in provocative clothing and sexualised positions. In some photos, she is topless. Furthermore, Perry seems to go out of her way to flaunt her raunchy side. She apologizes to Grigoriadis because the air conditioning in her car "smells like stinky pussy" (44). Grigoriadis balances this raunchiness in the article by asserting that, "underneath, Perry's just a good girl. She's only had a few boyfriends, says that casual sex 'grosses me out' and barely drinks or experiments with drugs" (44). The discussion of her sexuality, combined with her support of political projects like the legalization of same-sex marriage (Penn and Perkins 28), is just enough to illustrate that she is not the kind of Christian that subscribes to a sexually repressive theology.

Instead, Perry is a kind of pilgrim who wants to acknowledge her Christian past while remaining open to other religious traditions. In a different interview, she describes her spiritual journey as "a pilgrimage. Sometimes it’s a lazy journey" (Gunderson “Teenage Dream"). Perry simultaneously represents herself as someone open to various forms of religious expression without taking any of them too seriously. In the Rolling Stone article, she qualifies her "Christianity" by saying that she is at best uncertain about the validity of the Bible (47). At the same time, she says she "also believes in extraterrestrials, and that there are people who are sent by God to be messengers, and all sorts of crazy stuff' (qtd. in Grigoriadis 47). This openness extends to her appreciation for the spiritual pilgrimage of her husband at the time of the interview, Russell Brand. Perry celebrates Brand's exploration of Transcendental Meditation and Hinduism, stating that she believes Brand's destination "will be complete nirvana" (qtd. in Grigoriadis 47). Perry suggests that the couple participate in their lazy spiritual pilgrimage together. The article ends with Perry describing a trip she took with Brand to a temple in India. While 
the temple keeper explains the proper ritual the couple should follow in order to honour the deity represented by a rock carving, the couple "were about to crack up laughing, because when [they] looked at the rock a certain way, [they] swore they were worshiping the Hamburgler" (47). Perry's spiritual competence is illustrated less in terms of her knowledge of various religious traditions, and more in terms of her approach. While she is open and willing to explore and possibly appropriate a wide variety of beliefs and practices into her own evolving spirituality, she takes none of it very seriously, including the elements of her religious past.

Approaching religion and spirituality with openness and a sense of humour informs the way Perry relates to her parents. Much like Kim Barnes, Perry acknowledges the way her parents gave her some of the basic building blocks she needed to succeed. Part of these blocks come from her family environment. Perry's sister Angela says the whole family "loves entertaining people, putting on a show" (qtd. in Grigoriadis 44). Grigoriadis makes a direct link between Perry's performance as a pop star and her parents' performances as Pentecostal ministers, suggesting that Perry learned lessons from her parents' preaching that made her a better performer (44). Perry's parents did much more than simply demonstrate their performance skills for their daughter, however. They offered practical support for her career. This began while Perry was beginning as a gospel star, but even after she moved out her parents supported her with money and even accompanied her to auditions with "secular" record producers (Grigoriadis 46). This parental support creates an interesting tension. While Perry's parents are presented as growth-stunting obstacles that Perry must overcome, they are also a positive influence that supports her on her road to stardom, success, and personal fulfilment. Perry resolves 
this tension in much the same way that Barnes does. While Perry's parents have good intentions, they themselves have stunted their own growth, and Perry must outgrow them in order to succeed. By calling herself a "modern Christian" who is open to various forms of sexuality and spiritual practices (without taking either too seriously), she positions her parents as antiquated Christians who repress sexuality and adopt a fundamentalist, evangelical theology.

Perry's representation of her parents as underdeveloped and childlike is evident in her descriptions of them and her interactions with them. On most occasions, when pressed about her parents' beliefs, she simply says that, "if my parents are happy with what they believe, then I'm happy to stay out of their way. We agree to disagree" (Halperin 30; also see Scaggs 30). She expands a little further on this topic in an article two years after the Rolling Stone article. When asked about her parent's position on same sex marriage she says:

My parents have actually become more accepting and tolerant now. We've all grown up and evolved and broadened our mindset. Sometimes people have a really picky way of eating, right? And they don't like certain foods, but a lot of times they haven't even tried those foods. Once they try or know or get educated and have the facts, they're more comfortable and there's no judgment on your shrimp cocktail. I know that sounds so strange, but it's this simple thing. A lot of people just aren't educated; they still have this 1950s mindset, unfortunately. (qtd. in Azzopardi 15) While Perry says her parents are "more tolerant," she stops short of saying they support same sex marriage (and later reports would suggest that they still do not). Perry then uses 
food preferences to describe her parents' lack of development. They have simply not "tried" things the way she has. If they did, they would grow out of their "1950s mindset" and accept not only same sex marriage, but Perry's neoliberal spiritual omnivorosity with a sense of humour as well. While her parents are undereducated, childish, and stuck in a bygone era, Perry is educated, playfully mature, and modern.

Perry not only evaluates her parents' political positions, but she also evaluates their religious and spiritual positions. Like Barnes' father, Perry's father has a vision that changes the course of his life. Perry is much more flippant than Barnes in her explanation of this event: "who knows if those visions were remnants of something else?" she says, in reference to her father's frequent drug use prior to his conversion (qtd. in Grigoriadis 44). Just as Barnes supersedes her father's explanation with her own, from a position that she represents as more advanced spiritual competence, Perry offers an explanation that undermines that of her father. She does something similar while discussing her parents' practice of glossolalia. After making a joke about how speaking in tongues was as common as "Pass the salt" in her house, Perry contextualizes the practice by comparing it to "meditation or chanting," which "a lot of religions use" (qtd. in Grigoriadis). Not only does this description provide a point of reference for a "spiritual but not religious" audience who may have experimented with meditation and chanting in workshops, it also homogenizes a wide variety of experiences from vastly different contexts. Perry's humour maintains that she never takes any of this too seriously, and by contrast those that do (i.e. her parents) are not advanced enough to appreciate the humour. This is most evident in her film Part of Me where she teases her parents about her song "I Kissed a Girl" (which describes a same-sex kiss) and her provocative photo shoots. While 
everyone else in Perry's entourage laughs at the jokes, her parents are noticeably uncomfortable. They are not exactly part of the group. They simply are not advanced enough.

\section{Her Whole Body Filled with Electric Current: Megan Fox's Deconversion Narrative}

Some of the core elements of Megan Fox's deconversion narrative that have circulated in the press are similar to those of Perry's story. Fox says that since she was a small child she wanted to be an actress and a model. Born in Tennessee, her mother and biological father divorced when she was just a toddler. Her mother remarried and the family moved to Florida where Fox attended a Christian high school and lived under the strict rules of her parents. In a 2010 article she briefly goes into more detail: "I was only around other kids while I was at school ... I wasn't allowed to have friends over, really" (qtd. in Jacobs). In a 2009 interview, she focusses more on the Christian high school she attended: "They had rightwing conservative teachers teaching Bible class ... They'd tell us how abortion was wrong, how evolution was wrong, how sex was wrong. I hated school" (Katz 100). Before she finished high school she convinced her mother to take her to Los Angeles to begin her career, and by 17 she had landed a regular role in a sitcom. Like Perry, Fox frames the exit from her conservative Christian home as the beginning of her career, as well as the chance for her to explore liberal politics. These appear to be the core elements of a therapeutic coming-of-age story that would garner an affective relationship with an audience. That is not the way the story functions for Fox, however, especially in the 2013 Esquire interview. 
Part of the reason Fox's narrative does not function as a typical coming-of-age deconversion narrative is that, prior to the 2013 article, there is no clear timeline for Fox's deconversion. Most articles and interviews skim over Fox's religious past in just a few lines. The articles, instead, focus on her sexuality and (more recently) her comparison of director Michael Bay to Hitler (for example, see Katz; Perry). The result is that, unlike Perry's story, which is repeated over and over, each time adding slightly more detail, Fox's story is scattered and requires assembly. In fact, when all of the pieces are put together, they even can seem contradictory. In a 2009 interview she says "I was raised Catholic. I went to Catholic school for 12 years," (qtd. in Wolf) but another article from the same year states, "Fox grew up Pentecostal" (Hirschberg). The discrepancy may be less intentionally misleading on the part of Fox and more a misunderstanding of those interviewing her. Based on a 2011 interview with Scott Feinberg and a 2012 interview, which appeared in Miami Magazine, Fox attended a Pentecostal church "complete with snake handling and revivals" until her parents divorced (qtd. in Myers). The reported age at which this happens varies from between three and ten (Myers). When her mother remarried, she moved to Florida and attended a Catholic school. It might be easy to presume that after this, Fox's upbringing was Catholic; however, in order to piece this together, one must consult multiple sources over the past five years and make some educated guesses. A by-product of this lack of clarity is that Fox does not have a clear parental figure on which to project her Pentecostal past. While her step-father is "strict," the articles rarely discuss him, his background, or his religious practices. Even if they did, if her step-father is, indeed, Catholic, it would only further complicate the projection. It would mean that Fox's biological father would be the patriarchal figure of Pentecostalism 
in Fox's past, and articles tend to mention him only in passing. More importantly, the follow up press tends to ignore the details about Fox's religious past in favour of more salacious details that the actress reveals in interviews. Although some of the core elements are present, Fox's narrative lacks much of what makes Perry's story a compelling deconversion narrative: Perry has a clear timeline, with a distinct before and after, parental figures on which she can project her Pentecostal past, and responsive follow up press that repeats the details of her story in a way that is sympathetic to the pop star. Fox, meanwhile, has an unclear, fragmented story that has no identifiable personification of her past and has been largely ignored by the follow up press.

The 2013 interview with Esquire does little to help clarify Fox's religious backstory. Instead, the discussion of Fox's Pentecostal past is imbedded in the description of her present. The third subsection of the article begins with a statement about her present: "She is preparing for the end times" (62). This is followed by a quote from Fox in which she says "I've read the Book of Revelation a million times" and quickly follows with "It doesn't make sense obviously. It needs to be decoded" (62). Fox then muses about several different possible interpretations about the final book of the Bible, including one that relates to celebrities. There is a striking lack of context for Fox's attraction to apocalyptic narrative at this point in the article. It is certainly not something limited to her distant past that she has left behind. It appears, instead, to be something that she uses to guide her present understanding of the world. This imbedding of the past in the present escalates when Fox talks about speaking in tongues. The opening line of this section is "Fox began speaking in tongues around the age of eight, when she attended a Pentecostal church in Tennessee" (65). This is the only mention of her Pentecostal 
childhood in the article. It does not mention her parents, or project the practice of speaking in tongues onto them, but rather focuses on Fox's own personal experiences. Furthermore, the line presents the ecstatic religious practice as something that Fox continues to do; she began speaking in tongues as a child. Fox goes on to discuss her current attendance at an unidentified church: "Even now, in the church I go to ... I could feel that I was maybe getting ready to speak in tongues and I'd have to shut it off' (65). Fox muses over how her fellow church attendees would react if she actually did speak in tongues, indicating that it is clearly not a church that accepts the practice. Nonetheless, it is enough that Fox continues to attend a church. Almost all of the follow-up press reported that Fox admitted she still speaks in tongues. Some even suggest that she was still a practicing Pentecostal at the time. Not only does the 2013 interview blur the timeline of Fox's deconversion, it begins to erase it entirely.

The way Fox talks about speaking in tongues seems to aid this erasure because she does not display the "appropriate" spiritual disposition the way Perry does. Perry makes a gentle joke, and then contextualizes the experience as the equivalent of several other meditative experiences, simultaneously exhibiting her knowledge of other religious traditions. Fox also tries to contextualize speaking in tongues by comparing it to other religious practices. Instead of meditation and chanting, however, she compares it to Santeria and voodoo rituals. Those religions have dealt with their own stigmas throughout the years, including a fabricated relationship to Satanism and a misunderstood connection with crime. The point of comparison for Fox is the "energy [that] is so intense" in both the Pentecostal and the Santeria setting (qtd. in Marche 65). Fox goes on to describe how speaking in tongues feels on a very physical level: "It feels like a lot of 
energy coming through the top of your head ... Your whole body is filled with this electric current. And you just start speaking, but you're not thinking because you have no idea what you're saying. Words are coming out of your mouth, and you can't control it" (qtd. in Marche 65). Later she even equates the experience to taking drugs, except that speaking in tongues comes with a divine protection that is absent with drugs. Lost in the middle is a description of the utility of glossolalia that is almost identical to the one that Perry offers. This utility is not, however, what Fox focuses on. The focus is how it feels for her. It is this focus that contributes to the difference in the way gossip media covered the two articles. Perry's focus is on the utility of the experience she largely attributes to her parents who have a worldview she no longer shares; it is a utility she rationally contextualizes using various religious practices. Fox, meanwhile, talks about the physical sensation of losing control, of giving up rational choice to a spiritual experience. As a result, she fails to enhance the kind of affective relationship with her audience that Perry is able to develop through her deconversion story.

This failure does not mean that Fox's performance in the interview is a failure. It is simply a different kind of success dependent on the context of the magazine. While Esquire has generally been viewed as a more "up market" men's magazine, as opposed to "down market" magazines like Maxim, Stuff, and Loaded, Jackson, Stevenson, and Brooks argue that this distinction "has become increasingly blurred" citing Esquire's former editor, Peter Howarth's defense of "his magazine's reliance on a steady diet of 'babes and boobs"” as evidence of this blurring (78). Interviews with the editors of this new kind of men's magazines, which came to prominence in the 1990s, reveal that part of their goal is "to be the 'reader's friend', while providing advertisers with access to a large 
market of aspirational consumers" (Jackson, Stevenson, and Brooks 73). This means that editors are trying to develop a similar kind of relationship between the magazines and the readers that Perry is trying to develop with her audience. Men's magazines do this through a "perpetual oscillation between a discourse of traditional heroic masculinity and a discourse of fallible, self-depreciating, anti-heroic masculinity" (Gill 213). On one hand, the magazines idealize traditional masculinity through its heroes, but develop a fraternal relationship with readers who feel inadequate next to these idealized versions of masculinity by presenting themselves (i.e. the editors and journalists) as equally inadequate. This oscillation is presented as a kind of "irony" which excuses the underlying sexism of the magazines. It is not only their inadequacy that forms this bond, but the mutual "consumption of women" (Gill 217). Rosalind Gill goes on to bluntly state that, "women are presented in men's [magazines] primarily as sex objects—contained in the plethora of soft porn images - who need to be 'managed' to serve men's interests" (217). Likewise, Tincknell et al. argue that the representation of women throughout the magazines, including images and interviews with celebrities, ensure that "only men can be represented as fully social subjects" (59). Female celebrities, then, in both the articles and the photos that accompany the articles, are presented as an object that men can look at while they bond with each other (and the magazine), and become reassured of their subjectivity (even if that subjectivity falls short of masculine ideals).

This assertion of male subjectivity is precisely what happens in Marche's article on Fox. The opening lines of the article clearly position Marche as the subject of the story, with Fox as the object: "Deep in her house, Megan Fox and I are discussing human sacrifice. I tell her about an Aztec ritual" (62). The opening section of the article is six 
paragraphs long, and almost half of it consists of Marche's description of the Aztec ritual for Fox. The description leads her to suggest that being a celebrity is somewhat like being a sacrifice. Unlike the Katy Perry article, in which Grigoriadis fades into the background, Marche clearly presents himself as an authoritative subject in the article. If this positioning is too subtle, the second section makes it much clearer. It begins with a lengthy description of Fox's physical appearance, a description that would fit well in a first year class on the male gaze:

The symmetry of her face, up close, is genuinely shocking. The lip on the left curves exactly the same way as the lip on the right. The eyes match exactly. The brow is in perfect balance, like a problem of logic, like a visual labyrinth. It's not really even that beautiful. It's closer to sublime, a force of nature, the patterns of waves crisscrossing a lake, snow avalanching down the side of a mountain, an elaborately camouflaged butterfly. (62)

Marche's objectification of Fox is almost over the top. He compares her with various natural phenomena to be studied and explored. Marche continues this objectification in the following paragraph where he compares her to pinball machines and muscle cars, objects with which men play. To him, Fox, is not just any object. She is a mysterious object, a "problem of logic," "a visual labyrinth" and it up to "us" (Marche, Esquire, their readers) to explore that mystery. Marche, however, is frozen in awe. He is "shocked" by her appearance, stunned into momentary inaction. He is not quite the gritty male subject that Benicio Del Toro, Leonardo DiCaprio, or James Purefoy present in the pages surrounding the Fox article. He, like his readers, is momentarily stunned. He recovers, 
but the pause is enough to align him with his readers who are encouraged to be equally stunned by Fox's face, which is conveniently pictured on the page facing this text. Fox provides the object that Marche and his readers can gather together and look at, explore, and marvel about. ${ }^{25}$ She is the catalyst for the fraternal relationship that Marche and the magazine develop with their readers, raising their value as commodities, and then marketed to advertisers.

Despite this overwhelmingly sexist portrayal of Fox as an object, Fox is not necessarily without agency. Even in the article itself, Marche writes "her agent has to beg her to read scripts or do magazine shoots so she isn't lost or forgotten. Her body, her perfectly symmetrical bombshell body, is what makes money and pays the bills, she knows that" (65-66). On one hand, this fits with the profile of a stereotypical sex symbol who "offer[s] herself to the gaze of men" (Dyer Heavenly Bodies 227) ${ }^{26}$ It also hints at her agency, her choice, and her motivations for participating in her own objectification. Fox goes into much more detail in a New York Times Magazine article. After listing several of Fox's more salacious comments to the press, Lynn Hirschberg asserts that "none of these comments were accidental" and that some "may have been fiction" because Fox "understood instinctively that noise plus naked equals celebrity" (57). This is the way Hollywood is, Fox explains in the article:

All women in Hollywood are known as sex symbols. You're sold, and it's based on sex. That's O.K., if you know how to use it ... I've learned that being a celebrity is like being a sacrificial lamb ... And I created a

\footnotetext{
${ }^{25}$ This is only a sample of the way Marche objectifies Fox in order to solidify a positive fraternal relationship with readers. Elsewhere in the article Marche compares Fox to buffalo and suggests she is the last of the beautiful women who inspire creative men.

${ }^{26}$ Dyer bases his profile of sex symbols on Marilyn Munroe as the quintessential celebrity sex symbol.
} 
character as an offering for the sacrifice. I'm not willing to give my true self up ... When I sit down to talk to men's magazines, there's a certain character that I play ... She's not fully fleshed out—she doesn't have her own name — but she shows up to do men's-magazine interviews. There's something so ridiculous about always being in your underwear in those magazines, and you know the interview is going to run opposite those pictures. So, there's a character that talks to all of them ... You have to be put in a box in this industry so they can sell you ... They need hits on their blogs or sell their magazines. So everyone is something. And if I'm not a party girl, which I'm not, I then have to be the outrageous personality. (qtd. in Hirschberg 57)

Fox is playing a different character in the New York Times Magazine, one that "embodies a presentation of knowingness and confidence, as one who is entrepreneurial in her performance of sexiness, and that offers the possibility for new formulations and alternative figurations of female sexuality" (Evans and Riley 277) ${ }^{27}$ Even so, even if Fox's persona of a calculating celebrity is false, there is at least an awareness of the kind of role she plays in men's magazines. She is aware that she will become an object that editors and journalists will use to sell copy. She also knows that she cannot just be the "perfectly symmetrical body." She must play the role of the outrageous person in order to get attention so that men look at her body, lust after her body, and develop a fraternal

\footnotetext{
${ }^{27}$ Evans and Riley examine the way women readers react to sexualized and objectified celebrities. They find that women often admire the celebrities for capitalizing and investing in their appearance in order to gain a market advantage, while simultaneously envying the resources celebrities have to maintain their appearance. The women in their study exhibit little concern regarding the inherent sexist ideology which accompanies the sexualisation of celebrities.
} 
relationship with each other and the men's magazines. She increases the value of her own celebrity commodity because she presents herself as a willing sex object, willing to say outrageous things in order to keep the attention of male audiences.

Fox has a deconversion narrative. Whereas she once self-identified as a Pentecostal and attended a Pentecostal church, she no longer does either. Despite this, her deconversion narrative does not function like Perry's narrative. Perry's deconversion narrative is a more typical coming-of-age deconversion narrative. She presents a clear before and after narrative in which her Pentecostal past presents an obstacle in her path to becoming a fully realized individual and a pop star. Perry presents the narrative in such a way as to make herself seem like part of the same group as her audience; she performs the right spiritual disposition toward her Pentecostal past, the ecstatic experiences of her past, her parents, and her current spiritual explorations. When Fox speaks of her Pentecostal past and speaking in tongues in the Esquire article, it is not to make readers feel as though she is one of them; it is to make herself seem both sensual and outrageous. Fox's description of her "whole body filled with this electric current" while "words are coming out of your mouth, and you can't control it" is very sexualized (qtd. in Marche 65). As noted in chapter two, many other authors make the connection between sexual and religious ecstasy. In this case, however, with a photo of Fox lounging in provocative lingerie on the facing page, it functions less as an attempt to comment on a larger patriarchal system, and more of an effort to titillate in an outrageous manner. Her comparison of the ecstatic experience to voodoo and Santeria furthers the outrageousness of her description. There are still limits to what she says. Her discussion of theology is muted, for example. If her men's magazine character was labelled as a conservative, or 
even devout Christian, that would not provide the commodity value that either the magazine or Fox is looking for. Though Fox does not present the kind of spiritual disposition that Perry performs, it is also not a traditional Pentecostal disposition. Instead, she evokes speaking in tongues as a "crazy," but quasi-sexual religious experience that makes her standout against a sea of other "symmetrical" women. It exploits the stereotypes of Pentecostals in order to make herself more interesting and desirable. It participates in an exoticism of the Pentecostal practice in order to raise the value of her own commodity.

\section{Conclusion: Literary Celebrities and Author-Commodities}

Making a connection between the way entertainment celebrities promote themselves as commodities and the way authors promote themselves is not straightforward. As Margaret Atwood once said, "book writers have never been rock stars or movie stars" (qtd. in Wagner). Scholars who study literary celebrity tend to agree, to a point. Joe Moran suggests that literary celebrity "in the United States has been conferred on authors who have the potential to be commercially successful and penetrate into the mainstream media, but who are also perceived as, in some sense, culturally 'authoritative"" (6). Wenche Ommundsen argues that the perception of cultural authority is based on "the notion of an author as a cultural hero unsullied by the manipulations of commercial or popular culture" (245). However, she goes on to argue that authors are able to gain "a distinct brand of fame" by flaunting this unsulliedness, usually by showing a reluctance to promote themselves, or a disinterest in their own celebrity (245). Moran examines the way that various reclusive authors in the United States perform this 
disinterest in a way that increases their celebrity rather than diminishes it. Even authors who are not reclusive, like Sherri Reynolds, perform a certain amount of reluctance to preserve the image of themselves as somehow above popular culture. Lorraine York adds that, while authors do often rely on media interviews to promote themselves and their work, "this dependency does not operate as intensively as it does between entertainment celebrities and media outlets, each of whom desperately needs each other. While [an author] may need media for the purposes of promoting her books, she is not as consistently or deeply dependent on general and frequent media 'coverage' as an entertainment celebrity aspirant is" (14). There is far more pressure on Katy Perry and Megan Fox to reveal more and more elements of their lives in order to remain current and competitive in the celebrity market than there is on authors like Toni Morrison or Margaret Atwood. Furthermore, while academics may exchange literary gossip at department functions, literary celebrities rarely face the same level of attention that entertainment celebrities do. Elements of an entertainment celebrity's persona are circulated far more quickly than those of a literary celebrity, requiring much more frequent corrections, alterations, and in some cases, persona make-overs to remain competitive.

That said, York argues that literary celebrity and entertainment celebrity are often similar, even in the case of Margaret Atwood, who frequently appears in the entertainment section of newspapers. Like celebrities, authors promote themselves as commodities. In some cases, they present their own biographical narrative, performing the right emotions and spiritual disposition in order to position themselves as part of the same group as their target audience, much like Katy Perry does. In other cases, however, 
they do something more akin to what Stephen Marche does with Megan Fox; they position themselves alongside their audience as observers of their own characters. This is particularly true of those who write about Pentecostals. While their characters or subjects struggle to understand their ecstatic religious experiences in the context of the contemporary world and, faced with conservative theologies they are uncertain about, the authors themselves clearly state they do not share those struggles. Instead, they visit Pentecostal churches, do interviews with Pentecostals, and position their writing as a kind of experiment to imagine what it is like to be one of them; they talk about writing as if it were a kind of spiritual tourism, and subtly package the writing itself as an opportunity for readers to engage in a similar type of spiritual tourism. In the end, however, the authors retreat back to a disengaged position of neoliberal spirituality, a position familiar to that of their target audience. They exploit Pentecostals as authors, and this allows them to develop a stronger relationship with their audience, thereby increasing the value of their author-commodity. 


\section{Chapter Four}

\section{In But Not Of: The Conversion and Deconversion of a Reporter in Covington's Salvation on Sand Mountain}

In 1992, Dennis Covington was a freelance journalist in Birmingham, writing for the New York Times. He wrote stories on murders and kidnappings in Alabama and nearby southern states. Covington first encountered snake-handling Pentecostals while covering the trial of pastor Glendel Buford Summerford. The pastor of a snake-handling church was charged and convicted of the attempted murder of his wife using the very poisonous snakes he handled during services. While at the trial, a member of the church invited Covington to a service, and he accepted the invitation, initially because he thought it would provide context for the trial. Covington became fascinated with the group and spent the next few years with them, initially studying them, but later becoming part of their community. He handled snakes and even considered becoming a pastor himself. Eventually, however, he leaves the group and returns home.

This relatively small group of believers, located primarily in the Appalachian mountains base many of their unique practices on a literal interpretation of Mark 16:1718, which says "And these signs shall follow them that believe; In my name shall they cast out devils; they shall speak with new tongues; They shall take up serpents; and if they drink any deadly thing, it shall not hurt them; they shall lay hands on the sick, and they shall recover" (KJV). Snake-handlers believe that, in order to provide an opportunity for these signs to manifest themselves, they should have venomous snakes on hand during church services. When the Holy Spirit moves members of the congregations, they take one of these snakes out of its storage box and hold it while praying. There is no 
guarantee of safety for the practitioners, especially if someone misinterprets the movement of the Holy Spirit. Numerous practitioners have died or suffered severe medical conditions as a result of snake-bites.

Covington writes about his experiences, including his reasons for leaving the snake-handlers, in his 1994 memoir, Salvation on Sand Mountain. The memoir received numerous positive reviews as a moving, and sympathetic portrayal of the snake-handlers. The St. Louis Post-Dispatch said the book was "beautifully written" (Schmeling 5C) while the Washington Post said it was "not only an interesting, well-crafted account of religious cult snake-handlers, but also a lyrical work of art as beautiful at times as the Book of Psalms" (McLaurin D2). Covington's employer, the New York Times, also had high praise, saying the memoir was "brilliant, dire, full of grace" (Abbott). Equally positive reviews appeared in USA Today and the Los Angeles Times. Southern writers like Clyde Edgerton, Fannie Flagg, and Lee Smith endorsed the book (Weaver-Spurr 3). The positive reviews led to interviews with Covington on Dateline and National Public Radio. By the end of the year, Covington had won the American Book Award and had been nominated for the National Book Award. The book continues to be relevant. Da Capo Press issued a $15^{\text {th }}$ anniversary edition in 2009, and in 2010 it was required reading for all incoming freshmen at Jacksonville State University (Jackson).

Not everyone was impressed with Covington's portrayal. Academic reviewers, in particular, critiqued the book. Jim Birckhead says that the snake-handlers in Covington's book "lack depth and seem to serve as larger than life personae of caricatures" ("Snake Handlers" 273). Ralph Hood is even more emphatic. He says that Covington "feeds the darker stereotypical images of Appalachian men" (Rev. 54) by highlighting "outdated 
clothing, poverty, and the toothless" (56). Hood also suggests that Covington misled the snake-handlers, pretending to be one of them for a better story. Certainly, this is the sense that Hood gets from the snake-handlers themselves when he speaks to them. This assertion leads him to dismiss the book as "treachery, disguised as journalism" (55). Robert Orsi expands on this treachery in his 2000 book Between Heaven and Earth. In it, he uses Covington's book as the primary example of how a border between "good" and "bad" religion is maintained according to liberal Protestant standards. Orsi is particularly concerned about how the book ends, when Covington ultimately leaves the snakehandling church. Orsi argues that, in the scene of Covington's departure, a snakehandling pastor becomes wholly other, "making the world safe again for Covington and his readers ... who would ever confuse the author or oneself with this wild creature, one's own fantasies, needs, and hopes with his?" (181). In light of this ending, Covington's involvement in the church seems, to Orsi, "a long detour to re-establish the prejudices against snake-handlers many readers started out with" (183). Birckhead notes that many of the popular media reviews of Covington's book reflect this result as they "help to create and to reinforce Appalachian stereotypes to which the book itself partly contributes" ("Snake Handlers" 269). Covington, according to these reviewers, does nothing more than perpetuate existing, harmful stereotypes.

This chapter reads Covington's memoir as an outsider deconversion narrative: a deconversion narrative which tells the story of an individual's conversion and subsequent deconversion, all from a post-deconversion perspective. ${ }^{28}$ In part, this means that, unlike

\footnotetext{
${ }^{28}$ Unlike coming-of-age deconversion narratives, in which an individual is raised in a particular religious tradition and then leaves it while growing up, outsider deconversion narratives feature a conversion to an unfamiliar religious tradition followed by a deconversion.
} 
Orsi, Hood, and the other academic critics, it accepts Covington's involvement in the church as genuine rather than an elaborate ruse to gain access to better sources and, ultimately, produce a more dynamic book. Covington's participation in the community leads him to a deeper appreciation of his everyday life; it helps him achieve a happier, more fulfilling life. The whole experience is a jolt to Covington that opens his spiritual eyes a little wider. Covington frames his involvement in the community as a journey of self-discovery. In that respect, Covington's involvement with the snake-handlers appears to be part of an eclectic spirituality. What Covington does not discuss in the book is a change in his theology. His conversion to snake-handling Pentecostalism seems purely experiential rather than theological. In fact, the only time Covington does discuss theology is when he eventually leaves the group. It is when Covington finally sees that theological differences will prevent him from being a long-term member of the community that he finally leaves. This is not, however, the only way that Covington differentiates himself from the snake-handlers. He portrays them as poor, ignorant, and contemporary ancestors. Covington, meanwhile, presents himself as an educated, modern, middle-class man who is able to pilfer the antiquated religion of the snakehandlers for elements which enhance what he presents as his existing spirituality. While he comes to the group in search of something he is missing, he quickly discovers it with the snake-handlers and then outgrows them. Reading Covington's memoir as a deconversion narrative does not excuse him from accusations of exploiting the people in the snake-handling church, but rather helps to illuminate the way he uses them as an other against which he can celebrate his spirituality. It also shows the way that Covington 
continues a tradition of stereotyping Appalachian people, and the snake-handlers of Appalachia in particular.

\section{"He Was Also a Friend": Participant-Observers in Appalachia}

There is a long history of reporters and academic researchers writing about Appalachia in ways that harm those who live there, both in terms of supporting negative stereotypes as well as indirectly supporting projects which have disastrous economic and environmental impact on Appalachian communities. This history began as local colour stories written by journalists not long after the Civil War. Though the Appalachian Mountains stretch from Labrador down to Alabama, the focus of these colour pieces was the Southern Appalachian Mountains. Will Wallace Henry, for example, describes the "strange land and peculiar people" of Appalachia (qtd. in Billings, Pudup, and Waller 1) while W. G. Frost called the people "our contemporary ancestors" (311). The perception of Appalachian people that these stories helped to establish was one of a group who had been physically isolated from the rest of America, and had thus been unaffected by the progress of modernity. Appalachian people became viewed as "vastly out of step, culturally and economically, with the progressive trends of industrializing and urbanizing nineteenth century America" (Billings, Pudup, and Waller 1); they were increasingly portrayed as ignorant, dirty, violent, poor, and generally deviant. The perception crystalized in the stereotype of the hillbilly, which Anthony Harkins argues is based on the people of Southern Appalachia and the Ozarks. Harkins argues that "the portrayal of southern mountain people as pre-modern, ignorant 'hillbillies' is one of the most lasting and pervasive images in American popular iconography, appearing continuously 
throughout the twentieth century in nearly every major facet of American popular culture" (3). Harkins, whose study focuses primarily on popular culture examples, suggests that the image is "consistently used by middle-class economic interests to denigrate working-class southern whites ... and to define the benefits of advanced civilization through negative counterexample" (4). Through the stereotype of the hillbilly, Appalachian people become a "white 'other" (4). Reporters who come into the mountains to do local colour stories often reproduce this image.

While ridicule of Appalachian people for being poor, ignorant and out of touch has been a common response to this stereotypical image, it has not been the only response. David Whisnant examines several different "missionary" projects which engaged in economic, cultural, and educational uplift for the region. While the writing that accompanied these projects attempts to produce "the 'do something' urge," it ends up reiterating the hillbilly stereotype of Appalachian people who suffered from "physical isolation, depleted gene pools, pathological inbreeding, clan wars, [etc.]" (xix). At the same time, because they were represented as white, white middle-class Americans could "sympathize with them as poorer and less modern versions of themselves" (Harkins 7). This is especially true during President Lyndon B Johnson's War on Poverty of the 1960s. The Appalachian people were central in those projects, which emphasized the poverty of people who lived in the region. As Dwight Billings and his co-editors point out, "from viewing Appalachia as a traditionalist subculture, it was but a short conceptual step to viewing Appalachia as a regionwide subculture of poverty" (5). Part of the solution to the "problem" of Appalachia became an insistence that the children of Appalachia "mold themselves to bureaucratic conceptions of middle-class social 
organization and lifeways" (Whisnant xxi). Whisnant goes on to argue that this cultural assimilation was not the only solution. Numerous projects that, on the surface, claimed to inject economic growth into the area resulted in the opposite: companies capitalized on the "do something" urge in both the public and government organizations in order to get "cheap labor, land, raw materials, and energy" (xix). These missionary endeavors, argues Whisnant, exploited both the people and the land of Appalachia, while keeping all but a few in the poverty the projects were supposedly designed to alleviate. In other words, the portrayals of Appalachian people as hillbillies not only perpetuate a damaging image about the people and its culture, they also support exploitative cultural and economic projects which have lingering effects on the area.

Alongside both the ridicule and exploitation of Appalachian people was a tendency to romanticize them as "noble mountaineers" (Harkins 5). As Emily Satterwhite suggests, "for white Americans who worried the 'material abundance' promoted 'spiritual impoverishment,' Appalachianness purportedly offered 'authentic' ethnic white culture preserved apart from consumer society" (180). She goes on to argue that "Appalachianness provides white Americans with a safe, intelligible Other, more vibrant than generic whiteness but seemingly less threatening or alien than people of color" (222). Harkins concurs, arguing that "middle-class white Americans could see [Appalachian] people as a fascinating exotic 'other' akin to Native Americans or Blacks" (7). This othering of the Appalachian people draws on the same hillbilly stereotype that those ridiculing Appalachians helped create. As Harkins suggests, even though this celebration of mythic white mountaineers was in part designed "to delegitimize hillbilly caricatures [it] actually reinforced those portraits and perpetuated the idea that the 
southern mountain people were a separate 'race' in, but not of, white America" (5). As a result, it simply added to the multiple ways the hillbilly stereotype could be interpreted and deployed without disrupting the image itself. Appalachian people remain separate and out of step with the rest of "modern" America, though instead of laughably ignorant they become noble icons of the past, reminding middle-class America of what it has lost rather than a diverse, exploited group active in contemporary America.

Snake-handlers in Appalachia are particularly susceptible to both the ridicule and the condescending representation as "contemporary ancestors." As anthropologist Jim Birckhead notes, "popular narrative and visual representations have created a standard 'look' for 'snake-handlers' that positions 'them' as very much 'other' to 'us;' as spectacle or carnival side-show" ("Bizarre" 168). Fellow anthropologist Ralph Hood notes that popular fiction contributes to this positioning by depicting "serpent-handling believers . . . as uneducated people mired in poverty and provincialism" (Foreword xi). There are two, seemingly contradictory results of this positioning. On one hand, the popular texts about snake-handlers “are crowded with descriptors like 'bizarre,' 'weird,' 'zany,' 'crazy,' 'frenzied,' lunatic fringe,' and implicit and explicit suggestions of hillbilly moonshining, inbreeding, and low intelligence" (Birckhead "Bizarre" 171). In other words, snakehandlers are a curiosity that readers can marvel about. On the other hand, as Birckhead points out, "The 'otherness' of serpent handlers is further accentuated by the use of archival and file photos (and footage) ... The dress and hair-styles worn, background settings, and general 'look' serve to position 'them' as 'old timey,' archaic, not part of the contemporary world" ("Bizarre” 168). Although they are still othered, they occupy an anachronistic position in the contemporary world, embodying the past of the audience. As 
a result, snake-handlers are simultaneously part of a past the contemporary world has outgrown, and entirely different from both those who write about the snake-handlers, and those who read about them.

In the late 1960 s and early 1970 s a growing resistance to the stereotypical images of Appalachian people and the associated exploitation began to coalesce. As Stephen Fisher notes, there is a long, understudied history of "collective resistance" in the Appalachian region, including a strong labour movement (3). What distinguishes the movement that came together in the 1960s was that it was more focused on "outsiders," including industry and business based outside of Appalachia, people who owned land in Appalachia but did not live there and often had no familial connection to the area, and finally, writers and cultural producers who drew on stereotypes to represent Appalachian people. The movement included a number of academics who took Appalachian culture seriously. In 1978, a collection of essays titled Colonialism in Modern America: The Appalachian Case was published for the first time, and has since become a cornerstone in the burgeoning field of Appalachian studies. It crystalizes an understanding of Appalachian people as a native minority persecuted by the colonial forces of corporate America. The postcolonial approach to understanding Appalachia's relationship to the rest of the United States has become the dominant critical approach in Appalachian studies. A more recent example is Richard Cunningham, who adapts Edward Said's postcolonial theory to argue that Appalachian people are represented "as never really moving beyond some 'classic' period ... in a scheme based on a dichotomy 'advanced/backward"” (“Appalachianism” 127). Appalachian people become "Others" who are "not regarded as adults but as children ... not as schismatic but as archaic: not as 
legitimate offshoots but as arrested earlier forms — not as rejected brothers but contemporary ancestors" (129). Although Harkins, Satterwhite, Billings, and Whisnant do not explicitly draw on postcolonial theory the way that Cunningham does, the theory clearly influences their arguments. Of course, this approach is not without controversy. In a recent essay, Stephen Pearson systematically examines the way foundational works in Appalachian studies indigenize the settler Appalachian people, effectively erasing their complicity in the continued colonization of Native American land and culture. Despite this serious and valid critique, there is still room to draw on post-colonial theory to examine the way Appalachian people, and Appalachian Pentecostals in particular, are represented as "yesterday's people" (Weller 1), whether it be for the purpose of ridicule, to create sympathy, or romanticize Appalachian people as holders of a forgotten "white" soul.

Many researchers and writers position the Appalachian people they interview as "friends" in order to resist perpetuating stereotypes. Lauren Pond's coverage of the snake-handlers for the Washington Post provides an excellent example of this. At 1:30 p.m. on May 29, 2012, Pastor Mack Wolford was bitten by a venomous snake during a Pentecostal service. He refused medical treatment until it was too late and died at 11 p.m. that same evening. Wolford was somewhat of an anomaly among the snake-handling Pentecostals of the Appalachian Mountains. He courted publicity in order to fight against what he viewed as the suppression of religious freedoms; snake-handling is illegal in most Appalachian states. Wolford had been the subject of a feature in the Washington Post the previous November. By chance, Pond, the photographer who worked on that story was also at the service where Wolford was bitten and sat in the room with him 
while he died. On May 31, the Washington Post published an article by her in which she describes watching Wolford "through [her] camera lens ... [he] writhed, turned pale and slipped away" (C01). In the article, she grapples with her decision to remain on the sideline while she watched him die. She also grapples with her relationship with Wolford: He wasn't just a source and a subject in my year-long documentary project about Pentecostal serpent-handling; he was also a friend: We shared a meal at the cafe where members of his family work; he screened videos about himself for me at his house; I once stayed the night on his couch ... His passing, my first vivid encounter with death, was both a personal and professional loss for me. (C01)

Pond's positioning of Wolford as both a friend and a subject did little to stem the tide of ridicule that came after the death. Media outlets routinely featured the story as a quirky and bizarre tale from the south. Online comments and blog posts ridiculed the snakehandlers as insane and called for Wolford to be nominated for a Darwin award. At the same time, Pond's apparent friendship did not soften the blow of her article, and the surrounding coverage in the Washington Post regarding Wolford's death on the Appalachian community either. Even one year later, members of the community felt betrayed by the paper and its reporters (Harold 1A).

Pond's framing of her relationship with Wolford as something more than that of a reporter and subject is not unusual for journalists and ethnographers who spend an extended period of time researching and writing about Appalachian snake-handlers. In fact, many monographs begin with authors describing their relationship with the snakehandlers as a qualification for the study which follows, even when (as is most often the 
case) the authors/ethnographers themselves fade into the background for the rest of the book. Thomas Burton, who has written two books on the snake-handlers, writes "they are good friends ... some, I believe would stand by me in the face of any opposition. I am proud of their friendship" (11). Fred Brown and Jeanne McDonald have a list, very similar to Pond's, in the forward of their 2000 book The Serpent Handlers: "we joined the serpent handlers in their services, in their homes, at their dinners on the grounds, at their homecomings, at their revivals — and yes, unfortunately, at their funerals — we have come to know them in a very personal way" (xv-xvi). Brown and McDonald hint at a deeper involvement with the snake-handlers: they are not only friends, but they participate in the services. Likewise, Ralph Hood, one of the snake-handlers' most vocal defenders in both the academic and new media spheres, writes that he and his partner $\mathrm{W}$. Paul Williamson "have spent time with these believers as participant-observers in their church services (although neither of us has ever handled serpents), as guests in their homes, and as friends who keep in touch by telephone and email" (Them xii). Hood and Williamson mention their participation in the services of the snake-handlers "as participant-observers" but clearly point to the limit of that involvement, which stops short of handling snakes. Like Covington, David Kimbrough does not have the same limits. In the introduction to his 1995 book Taking Up Serpents, he describes himself as a “transplanted Appalachian" who feels "very much at home in the [snake-handling] church" (1-2). His participation in the church reflects his level of comfort:

I participated in churches as far as my personal beliefs would let me. When asked, I played guitar in services or acted as a Bible reader. I have handled snakes on many occasions, to the astonishment of the snake 
handlers. During one 'meetin,' I was asked along with the congregation, to fast for a sick woman who to my amazement improved. When I participated in the services, the congregations were more open and receptive toward me. (6)

Although his limits are much broader than those of Hood and Williamson, his beliefs still represent some limits in his involvement. Kimbrough reinforces these unnamed limits, along with the separation between himself and the snake-handlers, by using dialect with quotation marks. Furthermore, while he trumpets his participation in the community as an important qualification, he points to the practical value of his participation: the people of the church were more comfortable around him and shared more openly with him. His participation allowed him to get better material and improve the quality of his book. Despite this, Kimbrough is careful to emphasize the fact that the people of the church are not only subjects: "I have made friends who have influenced my life ... and continue to have close relationships with them" (8). For all of these authors, the snake-handlers are not simply subjects to be studied, but are also not just friends.

This complex relationship between authors and their subjects is largely a result of a participant-observation approach to research that Hood and Williamson mention. This approach has been a staple of anthropological and sociological research since the 1940s. It requires researchers to become involved in the communities they are studying and, to some degree, become part of those communities. There are two important advantages to this approach. As Hillary Crane points out subject groups can be suspicious of researchers, casting them "into more familiar categories for outsiders - as colonial authorities, religious missionaries, or CIA spies" (11). Even when the suspicion is not 
quite that pronounced, the presence of a researcher may significantly alter the behaviour of subjects. Spending time with a community of subjects and becoming part of it helps to ease these challenges to research. As H. Russell Bernard suggests, blending into a community of subjects leads them to act more naturally and share details they might not otherwise feel comfortable sharing (256). Bernard also points to another benefit of the participant-observation method: "it produces the kind of experiential knowledge that lets you talk convincingly, from the gut, about what it feels like to plant a garden in the high Andes or dance all night in a street rave in Seattle" (256). In more reflexive studies, this can lead researchers to write explicitly about their own experiences and feelings. In studies more focused on the subjects themselves, it can provide important background information which enhances the study of the subjects. Contemporary studies most often land somewhere between these approaches.

There are, of course, risks involved in participant-observation. One of the most often cited risks is what Bernard and others uncomfortably refer to as "going native" (262; also see Dewalt and DeWalt 6; Merriam 125). Researchers normally maintain an internal distance from their subjects, even when engaging in participant-observation. Sharan Merriam calls it a "schizophrenic" activity, where researchers manage multiple identities and goals (125). At times, however, researchers abandon their old identity and fully integrate into the group. This can mean a religious conversion for researchers studying religious communities. Even when researchers do not fully convert, remaining open to belief and experience can change the researcher. In the 1960s, theorists like Victor Turner and E. E. Evans-Pritchard advocated a certain openness to belief in order to fully understand religious experiences, including spirit possession. They suggest that 
when a researcher actually believes in the spiritual dimension of religious experiences it enhances the research. Susan Harding advocates a more moderate position of "stand[ing] in the gap between conscious belief and wilful unbelief," a position she refers to as "narrative belief" (xii). Nonetheless, taking these positions runs the risk of criticism and skepticism from colleagues who may claim that researchers lose objectivity and compromise their research by becoming mouthpieces for the religious groups they were meant to study. Bernard dismisses these concerns (262), but as Katharine Wiegele suggests, they still loom large for ethnographers, especially those who are not established (83). The risk, then, is not simply a dramatic transformation of a researcher's identity, but a loss of credibility within the researcher's prospective audience.

These risks are enhanced in what Crane calls "missionizing communities." She suggests that these communities tend to view a researcher as "a potential convert" whose interest in a religious community is interpreted as "a personal interest in conversion" (11). Robin Willey experienced something similar while, as a young academic, he did fieldwork in a Pentecostal church. Citing studies by Susan Palmer and James T.

Richardson et al., and Meredith McGuirre, he suggests that religious subjects often "view researchers as people whom they wish to convert" (para. 3). Wiley says that as he began his study of a Pentecostal church he was unprepared for "the situation of subjects who wanted to 'save' me as much (or maybe more than) I wanted to study them" (para. 5). Palmer concurs with Wiley, stating that it was difficult for her "not to misrepresent [her] identity, since most of [her] informants ignored [her] staunch protests that [she is] merely a dreary academic, a boring social scientist doing [her] job. They insist that deep down, [she is] a lost soul desperately struggling towards the light" (106). Anthropologist Susan 
Harding reports similar experiences when speaking with fundamentalists and evangelical Christians. Her observations about the way they use language to interpolate potential converts come, in large part, from her conversations with subjects who try to interpolate her. A particular pastor "reframed [her] appointment to interview him into his opportunity to witness to [her] for an hour and a half' $(37-38)^{29}$. She found the experience challenging, not only because it was difficult for her to do the work she intended to do, but because the pastor's techniques began to impact her on a personal level:

The membrane between disbelief and belief is much thinner than we think. All I had to do was listen to my witness and to struggle to understand him. Just doing so did not make me a fundamentalist Baptist born-again believer, but it drew me across that membrane in tiny ways so that I began to acquire the knowledge and vision and sensibilities, to share the experience of a believer ... that is precisely what it means to be "under conviction." You do not believe in the sense of public declarations, but you gradually come to respond to, interpret, and act in the world as if you were a believer. (58)

Narratives about skeptical reporters and academics who study Pentecostal communities and end up converting to Pentecostalism encourage Pentecostals to see researchers as potential converts.

Most notably, John Sherrill tells the story of his own conversion from skeptical reporter to Pentecostal believer in They Speak with other Tongues, first published in

\footnotetext{
29 "Witnessing" here refers to the practice of telling one's conversion story with the explicit purpose of trying to convert those who listen.
} 
1964. The book makes frequent appearances on the syllabi of Pentecostal Bible colleges. The narrative is repeated and circulated in sermon anecdotes and subsequent memoirs, like Julie Lyon's 2009 Holy Roller and, to a lesser degree, Mark Richard's 2011 memoir House of Prayer No. 2. Covington, then, is not the only reporter or ethnographer who has been drawn into a deeper involvement with Pentecostalism than originally intended, due in part to the fact the Pentecostals themselves encourage such deeper involvement.

There is also a risk to the community the participant-observers study. As Bernard suggests, participant-observation "involves deception and impression management" (256). As a result, when participant-observers leave the communities they are studying and publish their findings, the communities themselves can feel betrayed. This can be even more problematic when an affluent researcher studies a disadvantaged community. Kawulich notes that the Muscogee community she studied was suspicious of her because previous researchers had published information which "community members [felt] should not be shared ... published their findings without permission ... or done so without giving proper credit to the participants who had shared their lives with the researchers" (para. 5). The long history of such anthropologists exploiting disadvantaged communities has led to the development of an ethical practice regarding such research. As DeWalt and DeWalt suggest, the deceptive nature of participant-observation in particular "requires that [researchers] assume an extra burden for protecting [their] research participants" (214). The American Anthropological Association and the American Sociological Association both have comprehensive codes of conduct which outline ethical ways to study communities. Even within these guidelines, however, there are gray areas which require researchers to make judgment calls. Crane, for example, 
wonders how much she should use the perception of researchers as "potential converts" to her advantage in her research, and whether that amounts to "misrepresenting [her] purpose" (11-12). Likewise, Wiegele says she "constantly asked [herself] how far [she] could go in participating without being dishonest and without misrepresenting [her] beliefs" (85). In order to guide these decisions, ethnographers tend to fall back on what DeWalt and DeWalt call "the primary priority of not harming participants in the research" even if that might mean not publishing some of the information or data that has been collected (221). Kawulich, Crane, DiCarlo, and Wiegele all report holding back some details regarding the communities they study in order to avoid harming them. In some cases, like that of Kawulich and the Muscogee community she studies, it means sharing the details of the research and gaining approval from the community before publishing it. The danger here with "missionizing communities," as Crane points out, is that the communities may have "an interest in representing [its] religious ideals both to and through the researcher. The community may see [the] research as a potential means to reach a broader audience with their message" (13). The researcher, then, is in a position to make judgmental calls on what may harm participants in a research study, and what would not harm those participants even if it contradicts the message they want to disseminate. Participant-observation, therefore, is not only a negotiation between identities for the researcher, but also a continual ethical negotiation in which the demands of research are weighed against the potential impact on the subjects of that research. Furthermore, the potential impact is amplified when researchers study disadvantaged communities, like the Appalachian snake-handlers. 
When Hood, Birckhead, and Orsi critique Covington's memoir, they do it from a social-science standpoint; they evaluate his work as if it were ethnography. Covington is not an ethnographer and his memoir is not an ethnography. Covington, who has a background in English literature and fiction writing, is acting as a journalist when he enters the snake-handling community. As Isabel Awad notes, anthropologists and journalists "have significantly different views of their sources ... in journalism maltreatment of sources seems to be part and parcel of the job ... in the name of the "public's right to know"' (922). Covington seems to endorse this journalistic approach to subjects when he acknowledges "the inevitable treachery that [stands] between journalist and subject" (20).While Awad systematically and convincingly deconstructs typical justifications for the mistreatment of journalistic sources, she nonetheless draws attention to a disciplinary divide which the academic reviewers of Covington's work fail to acknowledge. ${ }^{30}$ Furthermore, the dismissal of Covington's involvement and commitment to the snake-handling church as "fake" fails to take into account the history of both ethnographers and journalists being drawn into the communities they study, sometimes fully integrating into those communities. The sense of betrayal that the snake-handling community reported is hardly evidence of Covington's duplicity. Instead, it is evidence of how the community reacted to the published work. By examining Covington's book as a deconversion memoir, it allows us to read his attraction and participation in the community as genuine without excusing the way he represents what is a disadvantaged

\footnotetext{
${ }^{30}$ Awad is not the only scholar to critique the way journalists use their sources. Awad, for example, cites an earlier critique by Janet Malcolm who argues that journalists misrepresent themselves to get good stories (922-23). There have also been several controversies about the relationship between journalists and their sources, particularly surrounding undercover journalism. Nonetheless, Awad argues that within the profession, the guiding principles remain accuracy and the public's right to know rather than the well-being of sources.
} 
community, even when recognizing the difference ethical requirements between journalism and ethnography.

\section{"I was One of Them"}

Salvation on Sand Mountain is structured like a deconversion narrative. It tells the story of Covington's initial attraction to the snake-handlers, how he gradually becomes part of them, and how he eventually leaves them. Like other deconversion narratives, he tells this story from a post-deconversion perspective which results in the tension of postdeconversion hindsight. This tension manifests itself overtly as Covington frequently foreshadows his own snake-handling as well as his falling-out with the snake-handling pastors. More than this, however, it manifests itself in the way that he represents the snake-handlers as fundamentally different from him. Like coming-of-age deconversion narratives in which protagonists position themselves within a religious community, but are somehow never fully part of it, Covington represents himself as not quite part of snake-handling church he attends. Near the beginning, this is because Covington occupies the position of a participant-observer. By the middle of memoir, however, he considers himself part of the church. His representation of himself as different, therefore, is a function of the deconversion narrative: though he claims he was "one of them," he represents himself as never fully belonging because he can only fully realize himself as a person outside of the church. He simultaneously justifies his departure from the group while positioning himself within a spiritual group along with his potential audience.

Perhaps the biggest obstacle to Covington in affirming this spiritual identity is contextualizing his initial attraction to the snake-handlers. He does this, in part, by 
presenting himself as someone with "a rough-cut reckless side" (10) who is drawn to "the center of storms" (100). To illustrate this, Covington presents a brief biography filled with his search for an adventure "in which the risks were real" (51). When he quits his job to pursue writing as a career and moves with his wife from Ohio to Birmingham, he presents it as "a wonderful moment ... the ultimate rebellion" (51). His writing career, however, gets off to a sluggish start. Meanwhile, his wife suffers a miscarriage. The combination leaves him with a sense of "desperation" (51), ultimately leading him to search for a new adventure. This time it is as a war correspondent in El Salvador where he genuinely fears for his life: "I found the antidote for conventional life," he says. "I got the shit scared out of me" (52). Covington gives up his career as a war correspondent when his wife becomes pregnant again. Once again he finds himself stuck, and this time he directly relates the sensation to religion. He is unsatisfied with his half-hearted participation in the mainline Christian church. "Something is missing," he writes, when he describes himself sitting in church next to his wife (55). "I had reached that point in the middle of looking for something when you have forgotten what it is you have lost" (55). This is how Covington describes his "spiritual condition" just before encountering the snake-handlers (55). He contextualizes his attraction to them as, at least in part, another episode in a cycle of his search for adventure and thrills which jolt him out of a desperate complacency.

Covington begins to see his involvement with the snake-handlers as a personal journey very early on when covering the Summerford trial. When speaking to Summerford's wife, she describes the experience of handling snakes: "It makes you feel different. It's like just knowing you got power over them snakes" (qtd. in Covington 43). 
Covington says "the moment Darlene Summerford told me what it was like to take up serpents, I knew the real story wouldn't be over until I'd seen and experienced what she was talking about for myself" (44). In his spiritual condition of desperation and lack, the snake-handlers seem to offer him an exotic, powerful experience. When he attends his first service, he describes it as "exhilarating and unsettling;" by the end of the service, he finds himself "in a heightened and confused state, as though the pupils of my spiritual eyes had been dilated ... Whatever this was about, I wanted to experience more" (11). As he continues to attend services, he finds himself participating more and more, though at the time he does not understand why. "I was moved by something I could not name," he says. "It was like desire, and not like desire, a longing for something that could not be possessed" (120). It is this longing which propels him to finally handle snakes and have an ecstatic experience himself, an experience which leaves him with a rejuvenated sense of supernatural mystery.

Covington is careful not to offer any clear theology to accompany the supernatural mystery he discovers. When Covington finally handles a snake during a service, he describes the experience as "giv[ing] in;" he is "possessed by the sacred" and loses his sense of self (169). The language here is vague at best, containing no clear doctrinal positions about what the "sacred" is, what it means to lose yourself to it, and the consequences of the experience afterward. In fact, Covington undermines even his most innocuous doctrinal statements throughout the text. For example, he follows his assertion that he "knows Jesus" with a qualification that his "beliefs about the nature of God and man have changed over the years ... feeling after God is dangerous business ... Christianity without passion, danger, and mystery may not be Christianity at all" (177). 
Covington states explicitly that his experiences with the snake-handlers "open [him] to mystery in a way [he] had never been in mainstream churches" (136). This is what he takes away from his experience with the snake-handlers, not a clear theology.

In fact, what prompts Covington to leave is, at least on the surface, his reluctance to accept the theology of the snake-handlers. Specifically, he disagrees with their doctrine on gender roles. The snake-handlers, meanwhile, argue that the Bible has prescribed specific gender roles which do not permit women to preach, cut their hair, or wear pants. When Covington gets his first chance to preach, what becomes his only chance, he preaches gender equality inside and outside the church. He doesn't get very far before he recognizes he is out of place. He cedes the stage to Punkin Brown who preaches a short sermon to refute what Covington has said. Brown singles out the female photographer, wearing pants, who accompanied Covington to the service and directs his aggression toward her. Covington describes Brown as "grotesque and funny looking" while he is preaching (235). His sermon is punctuated with a noise, which Covington describes as sounding "like steam escaping form an underground vent" (234). Covington represents the sound as "Haaagh" interspersed through Brown's sermon (234-35). The last words of Brown's that Covington records are directed toward Covington himself "It's a lie Dennis! ... There's no truth in it! It's a sin!" (235). This marks the end of Covington's involvement in the church. Still, Covington insists that the dispute is "not about snakes, or about the role of women in church. It was about the nature of God" (239). While Covington is content to emphasize the mystery of belief and downplay any theological assertions, the snake-handlers explicitly and clearly make theological statements about the nature of God and what He expects from His followers. In essence, Covington 
reinforces his spiritual identity by contrasting it with the religious identity of the snakehandlers in terms of their theological beliefs and the way they talk about those beliefs; it is a contrast that Covington largely presents through an absence of his own theology (i.e. snake-handlers have a restrictive, explicit theology, while Covington has only an implied, liberal theology). That contrast is part of what makes the memoir a deconversion narrative.

Orsi critiques Covington for the representation of Brown during this dispute. Orsi suggests that in this scene, Brown "has become a nightmare figure, a subterranean creature, a snake himself" (181). Orsi points, in particular, to the sound that Brown makes: “Covington makes sure we hear this. 'Haagh' appears ten times on a single page - and it is thus - 'haagh!' - that he reestablishes the border between himself and the handlers" (181). This border is the one between good religion and bad religion that Orsi argues permeates American culture. Thus, by "re-establish[ing] the prejudices against snake handlers many readers started out with, alongside whatever fascination drew them to the work as well" (183), Covington, argues Orsi, positions himself as subscribing to "good" religion, the kind outlined in chapter one of this dissertation. Orsi goes on to argue that the last chapter of Salvation on Sand Mountain constitutes an "abrupt change of voice" (181): "until the last night of the time he spent with the snake handlers, Covington offers a worthy model for an engaged, interpersonal, participatory religious study" (180). As mentioned earlier, Orsi approaches Covington's memoir as an academic study of a religious other, rather than as a story of a personal spiritual quest, and ultimately, a deconversion narrative. Like other deconversion narratives in this study, Covington represents himself as somehow different than those around him in the 
religious community he ultimately leaves. While Orsi misinterprets the final chapter as an abrupt change of voice, it is actually a culmination of the subtle ways Covington separates himself as more modern, intellectual, mature, and advanced than the snakehandlers throughout the book.

Covington explicitly draws contrasts between himself and the snake-handlers based on region, class, and education. This begins in the prologue, where Covington represents himself as part of the urban south that resists cultural invasion from the North (xvii-xix). Though the snake-handlers also fight against a cultural invasion, Covington characterizes their approach as distinctly "country" (xix): "They threw up defenses. When their own resources failed, they called down the Holy Ghost. They put their hands through the fire. They drank poison. They took up serpents" (xviii). Initially, the distinction here is between how the "we" of the south generally reacted to a perceived cultural invasion from the north, and how "they" are a particular example of that reaction. Yet, just one page later, the separation between "we" and "they" becomes slightly more expanded as "we" becomes people who live "in the City" whereas "they" are from "the country" (xix). This gap between us and them widens as the text moves along. Covington points out the "angular, hand-me-down look of Appalachian people" (2) early in chapter one, and expands upon it in chapter two with a full two pages describing the appearance of the Appalachian people: they wear "out of style" clothing and have "thick-lidded and vaguely menacing" looks (36). The section begins with Covington suggesting that there was a "contrast in appearance between us [journalists] and the people attending the trial" which brought Covington into contact with the snake-handlers in the first place (35). Despite this, Covington offers no description of how the journalists appear. Their 
appearance becomes the unspoken norm against which Covington judges the Appalachian people. Covington explicitly links the appearance of the Appalachian people to class when, at the end of the passage, he writes that their appearance has "to do not so much with their religion, [he] reason[s], as with their poverty" (36). Elsewhere, Covington clearly identifies himself as "middle-class" from a "quiet, sober neighborhood" (8). While he becomes bored and frustrated with the quiet and sobriety at times, his forays into what he portrays as the boisterous, dangerous, and spiritual lower classes are temporary. As a result Covington remains middle class and urban despite his engagement with what he represents as the lower class snake-handlers of the rural, Appalachian south.

Covington reinforces this separation every time it seems that he is drawing too close to the snake-handlers. There are only four occasions when Covington refers to himself and the snake-handlers together as "we" or "us," and each time the unity is almost immediately undermined. All of the four instances come when Covington describes services where he has an ecstatic experience, either accompanying a woman speaking in tongues with a tambourine (68) or taking up snakes himself (101-2). However, even during these services, Covington juggles the pronouns: "And it seemed as though nothing could happen to any of us that would harm us, although in retrospect of course, I knew that not to be the case. We felt invulnerable, forever alive" (102). The movement in and out of referring to himself using the same pronoun as the snakehandlers is important here. While, as a group, Covington and the snake-handlers feel "invulnerable," only Covington knows this is false in retrospect. Not only does this provide a reminder that Covington's engagement with the snake-handlers is temporary, it 
points to another contrast that Covington falls back on frequently: one of intellectual maturity. During a particular service, after Covington had already handled a snake, he describes a tension between his participation in the ritual and his "restless stubborn, intellect" (164). While he withdraws to the back of the church in order to remain an observer, the man preaching shouts “They say we've gone crazy! . . W Well, they're right! ... I've gone crazy! I’ve gone Bible crazy! . . Some say we're just a bunch of fanatics! . .. Well, we are!" (166). Although both Covington and the snake-handlers seek spiritual ecstasy, Covington must find balance between intellect and spiritual engagement while snake-handlers have no such impediment; they are self-acknowledged Bible crazy fanatics.

Perhaps the most uncomfortable dichotomy that Covington creates between himself and the snake-handlers is temporal. Not only are Covington's snake-handling days in his past, he reframes the snake-handlers as part of his heritage. At first, Covington simply suggests that "the snake handlers' ancestors ... were [his] ancestors too" (84). As the memoir progresses, the present-day snake-handlers become contemporary ancestors. This is clearest in a dream that Covington recounts near the end of the book. In the dream, he picks up a hitch-hiker in Appalachia and drives her to a house full of people: “"What year is this?' [he] ask[s]. They laugh—it's 1908 or something like that. 'Where we live,' [he] say[s], 'it's 1993"' (192). Immediately after this, the people in the house start to sink in the mud and Covington desperately tries to save them. While this is a dream, it helps frame Covington's thoughts when he is about to leave the church: "I had found my people. But I had also discovered I couldn't be one of them, after all. Knowing where you come from is one thing, but it's suicide to stay there" (236). Even though 
Covington has no clear familial relationship to the particular snake-handlers he was involved with, or to any snake-handlers for that matter, he recasts them as part of his own past, one he has left behind. To stay with them, he suggests, would be to turn back time and ignore the progress of the modern world. They are part of the past; Covington is the present.

While Covington does not adopt a new theology, he does hint at how his life has changed and become fuller as a result of his experience with the snake-handlers. The book ends with an anecdote from his childhood where his father comes to find him for supper. The anecdote sets up the last line of the book: "He always came to the place where I was before he called my name" (240). In this line, Covington is talking about both his father and God. Elsewhere, Covington links his father to messages from God (54-5), and the sentence immediately before the anecdote asserts that Covington's dispute with the snake-handlers is about "the nature of God" (239). For Covington, God comes to individuals where they are geographically, temporally, and theologically. In other words, in Covington's implied theology, God is less concerned about where an individual is, and more concerned about loving interaction. Covington's theology, then, does not change because of his interaction with the snake-handlers. In fact, as mentioned above, his ecstatic experiences seem almost atheological. Instead, he becomes more sensitive to the presence of the divine in the everyday. In the prologue, he takes special notice of spirit trees, trees with empty bottles hanging from the branches. He positions the practice as a "country" one (xv). He then goes on to explain "what we do with evil spirits in the City" using an iron plant as an example (xix). His description of the workings of an iron plant imbues the material production of the plant with a dangerous, spiritual quality. The 
description ends with "That's the kind of South I'm talking about" (xix). The description works on several different levels to illustrate how Covington has developed as a result of his experience with the snake-handlers. He is more sensitive to spiritual qualities all around him, even in the factories. God comes to him where he is, even overlooking an industrial plant. In fact, by changing his personal perspective, Covington is able to find beauty in this plant, which is the site of poor working conditions and employee injuries; his new spiritual sensitivity aestheticizes and even spiritualizes industrial capitalism. More than this, however, the city is a place that takes parts left behind, melts them down, and makes something new. This is what a Southern City does, for Covington, and this is what he has learned to do with what the snake-handlers have given him. He takes it and uses it to write more authentically southern books, and enrich his life with a new sense of spiritual enchantment.

\section{Conclusion: Neoliberal Snake-Handling}

Covington's deconversion narrative is perhaps the least neoliberal in this study. This is partly because Covington does not go on to develop an eclectic spiritually which overtly supports his pursuit of a fulfilling, fully realized self. Instead, he returns to his "home" church which he attends with his wife. Further complicating Covington's religious/spiritual identity is the fact that he identifies his church as Southern Baptist in interviews, a fact that is peculiarly absent from the memoir. That denomination would situate him as a conservative Evangelical Christian, decidedly on the other side of the good/bad religion line. Despite this, Covington's memoir downplays his conservative theological leanings and instead emphasizes a neoliberal approach to religion. His 
attraction to the snake-handlers is not about discovering a deeper spiritual or moral truth. It is about finding something that is missing for him personally. The snake-handlers help him find it: a greater sensitivity to the way he can incorporate spirituality into his daily, urban life. He can live his middle-class lifestyle without the sense of restlessness that plagued him earlier. Of course, he cannot stay with the snake-handlers in their rural, anachronistic setting. That would be a step backwards for him. He recovers what he has lost from the past and then moves on. The snake-handlers would not only hold him back, but also routinely hold others back on their journey toward self-fulfillment.

Covington, however, is not a child who learns these things as he grows up, which means it is not a coming-of-age deconversion narrative discussed in previous chapters. He is an affluent, middle-class writer, who enters a disadvantaged Appalachian community that has been routinely mistreated by other writers. Covington continues this mistreatment, not because he does not genuinely participate in the community, but rather because of how he distinguishes himself from them. Although he romanticizes their religious practices as somehow uncorrupted by the very consumerist lifestyle he finds unfulfilling at the beginning of the book, this very incorruptibility positions them as out of step with the rest of the United States. While Covington is educated, middle-class, and able to adapt the spiritual sensitivity he gains to contemporary life, the snake-handlers are undereducated, poor, and premodern by choice. His representation of them, and the reasons he leaves, ultimately supports the stereotypes which began at the end of the $19^{\text {th }}$ century and supported the exploitation of the Appalachian region and its people. Covington may not be an ethnographer, and it may be inappropriate to evaluate his interaction with the snake-handlers on the basis of an anthropological or sociological 
code of ethics, but his decisions about how to portray the snake-handlers are no less damaging. 


\section{Chapter Five}

\section{Not Real Good at Modern Life: Appalachian Pentecostals in the Works of Lee Smith}

In response to the stereotypical representations of Appalachian people that Cunningham catalogs, he urges Appalachian writers to start writing about, and therefore defining, themselves: "we Appalachian writers are en(cou)raged to fill in the blanks ourselves - to construct, out of inner necessity, a radical critique of both masterdiscourses ... to displace the categories of domination in both directions and thereby to push open not a vacuum but a creative space" (46). The directions Cunningham refers to are the North and the South; while the North uses the stereotypes of Appalachia to characterize all of the Southern United States, the South displaces those caricatures solely on the Appalachian people themselves, making them akin to "an Other's Other" (Cunningham 42). Appalachian literature written by Appalachians, according to Cunningham, would resist the definitions and stereotypes imposed on Appalachia by both the North and the South. Cunningham is clear that what he is calling for has already begun at the time his article was published in 1996. As an example, he points to Lee Smith's Oral History.

It is no surprise that Cunningham chooses a novel by Smith. Smith, who was born and raised in Appalachian Mountains of Grundy, Virginia, is perhaps the best known Appalachian writer outside of Appalachia, and one of the most championed authors inside Appalachia. Fellow Appalachian author Silas House once described Smith as "one of the region's most beloved figures and ... one of the few writers from Appalachia who always manage to tell the truth about the region without causing controversy or backlash" 
(17). Satterwhite cites several instances where Smith's fiction, particularly her 1988 novel Fair and Tender Ladies, is identified as the "definitive book about the Appalachians" (117). Her work is not only recommended above other Appalachian fiction as a required reading for "beginner-level instruction on Appalachia," but also above non-fiction books (Satterwhite 178). Smith's work has a strong scholarly appeal as well. There are at least four monographs focused exclusively on her work (D. Hill; R. Smith; Cook; Bennett) and hundreds of scholarly articles, including a special issue of Pembrooke Magazine which focuses on her work. There is even an anthology of collected interviews with Lee Smith (Tate).

Oral History is a particularly important novel for Smith's career, and for the way readers imagine Appalachia. The 1983 novel was a Book-of-the-Month featured selection, giving her national exposure she had not previously enjoyed. But it is more than simply the popularity of the novel, and its author, which lead Cunningham to select this novel as his primary example of Appalachian writers "filling the blank." Oral History is a family saga novel that spans nearly a century. There are multiple narrators, each of them unreliable, making it impossible to sort out what is an exaggeration and what actually happens. This is precisely why Cunningham holds the book up as a worthy example. Drawing on an unnamed "native Appalachian reviewer," Cunningham argues that Oral History is "a pastiche of every kind of stereotypical writing about Appalachia in the past hundred years" ("Writing" 47). Drawing attention to the unreliability of the narrators, and by extension, the stereotypical writing from which the narrative voices are drawn, points to what is left unsaid. According to Cunningham, readers "begin to hear the whispers of the authentic voice underneath, a voice present by erasure - a blankness 
made articulate" (48). A crucial part of this narrative strategy is the portrayal of Richard Burlage.

Unlike most of the characters in Oral History, Richard is not a native of Appalachia. Instead, he is an upper-class man from the city of Richmond, come to Black Rock (the town closest to Hoot Holler, the primary setting of the novel) as a school teacher, but also on a personal "pilgrimage back through time, a pilgrimage to a simpler era, back - dare I hope it - to the very roots of consciousness and belief" (Smith 97). His pilgrimage leads him both to a Pentecostal church in Hoot Holler, and a romantic relationship with Dory Cantrell. Cunningham equates Richard's journals to those of anthropologists and journalists who condescendingly write about Appalachia as "local colour." Richard proves naïve in his search, and leaves his quest, as well as two children and a broken-hearted Dory behind in Hoot Holler. By making his voice just as unreliable as the residents of Hoot Holler, if not more so, Cunningham argues that Smith resists dominant narratives about Appalachia. Most other critics of the novel agree with Cunningham's assessment. For example, Suzanne Jones suggests that Smith uses Richard and Jennifer, another outsider character, "to examine the causes and consequences of typical twentieth-century perceptions of Appalachia ... revealing the naiveté and the condescension that often characterize the outsider's perception of mountain people" (102). Likewise, Paula Gallant Eckard argues that while Richard "is a product of powerful Western influences and Latinate education, he is a kind of Other, a true outsider in the mountain community" ("Prismatic Past" 126). This is the dominant interpretation of Richard's role in the novel: as stand-in for outsiders who perpetuate the condescending 
narrative of Appalachian people as part of a contemporary past (for other examples see Soos; Billips; R. Hill; Hazelwood Donlon; Hendricks Wallace).

There is a problem with this line of interpretation of Richard's character, which Nancy Parrish raises in a short article: Smith consistently says that Richard is one of the two characters in her fiction with whom she most identifies. Parrish expresses a great deal of discomfort with equating Smith to Richard because it would "simply make Smith intellectually akin to all of the tourists who have been attracted to writing about the ‘difference' of Appalachia” (44). As Ostwalt suggests, Smith's representation of Appalachian religion "reinforce[s] notions that Appalachia has a sense of otherness about it, an exotic element in all facets of its culture including religion" (99). Parrish suggests that the difference between Richard (and what he represents) and the author is the author's "acute self-awareness" (44). Parrish never fully defines this self-awareness, but speculates it may relate both to the limits of fiction, as well as the fact that Smith's "book is a commodified means of preserving the perceptions about a region that has, for over a century, been treated as a commodity" (46). Parrish provides little evidence for either speculation. In fact, when set alongside Smith's other work and interviews, the difference between Smith and Richard's approach to Appalachia, specifically Pentecostals in Appalachia, begins to disintegrate.

Although most critics celebrate Smith for disrupting Appalachian stereotypes, I argue that her fictionalized deconversion narratives project those stereotypes onto Appalachian Pentecostals, creating a religious other within Appalachia. The first two deconversion narratives in this chapter are outsider deconversion narratives, where an individual who is not raised as a Pentecostal attends a church for a short time and then 
leaves, much like Dennis Covington. Both Richard, from Oral History, and Karen, from Smith's story "Tongues of Fire" (Karen is the other character Smith most often identifies with) enter a Pentecostal community in search of some spiritual or supernatural contact they lack, but reject the community after only a brief involvement. While Richard regrets his decision and laments his loss and the pain he causes, Karen dismisses her involvement as childish. Both characters ultimately see their experience as something they must outgrow to function in contemporary society, positioning Pentecostals as out of step with the rest of America. The chapter then moves on to Smith's novel Saving Grace. Saving Grace takes a very different approach to Appalachian Pentecostalism. It is a fictionalized coming-of-age deconversion narrative, in which Grace grows up as a Pentecostal preacher's daughter and eventually leaves the religious tradition. Where Grace ends up is not entirely clear based on the novel itself. In fact, the evidence seems to suggest that Grace reconverts after she is unable to succeed in contemporary life, a choice the novel depicts as a failure. Grace's inability to function in the contemporary world, and her subsequent irrational decision to return is a direct result of her upbringing within a Pentecostal community; she simply does not have the skills to function as a rational individual in the modern world. The final part of this chapter turns to interviews where Smith goes to great lengths to distinguish herself from Appalachian Pentecostal women, whom she affords only condescending pity. While she expresses some attraction to Pentecostalism, even fond memories of her experiences in the church, she firmly places herself alongside readers who stare at Pentecostals as if they were freaks. This position of Appalachian Pentecostals as an anachronistic, immature, and irrational other is all the more significant given the prominent place she holds in Appalachian literature. Smith 
uses outsider deconversion narratives and failed deconversion narratives to portray Appalachian Pentecostals as religious others, while celebrating a spirituality which embraces Appalachia, especially an upper-middle class Appalachia. If Smith helps to push open a creative space by resisting the stereotypes of Appalachian people, it is not a space which includes Appalachian Pentecostals.

\section{Richard and the Stench of Pentecostals}

Richard's reasons for leaving the city and coming to Appalachia, as he explains to Rev. Aldous Rife, a Methodist minister in Black Rock, are twofold. On one hand he wants "to make some contribution, however, slight, to the cause of civilization" but on the other, he also wants "to find in Nature the source of that religious impulse which has been stifled rather than nurtured by the rigid disciplines of the Episcopal Church, the church of my youth" (123). The narrative, which appears in the form of Richard's own journals written in the $1920 \mathrm{~s}$, focuses much more on the latter than the former. In this he has very much in common with Covington. Richard recognizes that there is something lacking in his "stifled" upper class, urban liberal Protestant religious experience. He longs to recuperate what has been lost, a closer connection with the source of religious impulse, by leaving the city and getting closer to nature. The Pentecostal church in Black Rock offers him a clear path to gain what he is looking for.

In Richard's first journal entry on the Pentecostal church, he unequivocally states "I have found it . . . a form of worship free of those Catholic restraints imposed upon by the spirit by the Episcopal Church" (137). He goes on to describe the simplicity of the "cabin" where the church meets, contrasting it with the cathedrals at Notre Dame and 
Chartes. Yet it is within these walls that Richard is able to connect with the spiritual in a way he was searching for: "never have I experienced the sense of majesty and trepidation — of awe at the literal presence of God — which I have found within these mud-chinked walls. It is as if we travel back through time, back through the centuries" (137). He continues to attend the church and take notes on what happens. He reports back both to Rife and his journal frequently, insisting "something is real here. I feel it" (141). At the same time, he knows that to fully embrace this real thing, this forgotten spirituality, he must give up control, a thought which causes him "a great sense of inner trembling, really with a kind of dread" (141). Nonetheless, he continues to attend the church and eventually feels as though he has "been accepted" by the congregation (153). Shortly after this, during a revival ${ }^{31}$, Richard feels himself propelled forward during an altar call, only to stop short of "getting saved" at the last minute as Autry Lilly, the Pentecostal Pastor, embraces him: "even at that moment, the moment of my putative 'salvation,' I recoiled for the odor of his body: he stank" (154). It is then that Dory Cantrell appears at the door, and Richard's attempts to find a lost sense of spirituality become entirely focussed on his relationship with her. He never returns to the church, or spends any significant time discussing his experiences there throughout the rest of the novel.

Richard's dramatic rejection of Pentecostalism is not entirely surprising. Throughout his experiences in the church, Richard goes to great lengths not only to separate himself from them, but to demonstrate his superiority in ways that are much

\footnotetext{
31 "Revivals" are special services held by a church or group of churches designed to enliven current members and attract new members. Revivals can last a week or more in which services are held each night of the week.
} 
more explicit than Covington's. He consistently refers to himself as a "sojourner" (141). When he feels accepted by the church, he "remain[s] a sojourner still. [He sits] among them, but near the back, still as much observer as participant" (153). Even when he moves toward the altar, he writes, "I remained a sojourner still—it pains me deeply to admit this - I was observing my actions even as I performed them" (154). Like Covington, what separates Richard from the believers around him is the fact that he has a modern self-awareness, a commitment to reason and control over himself that he has trouble relinquishing. This manifests itself partially in his dismissal of the theology that Lilly preaches. Richard writes that "I found myself listening to his (often comical!) grammatical errors rather than trying to grasp his intent" (153). Richard asserts his superiority by mocking the Pentecostal preacher's lack of education. These assertions are even stronger as Richard casts the Pentecostals as contemporary ancestors: "I know, although they do not, that I am here at the end of something, that these days soon shall pass from the earth and that these people and all their kind shall pass AS WELL" (138). What follows this statement is a long list of the technological and industrial developments which he predicts will not only spread from the city to this rural area, but drive the deep spirituality out of the area when they come. Since Richard comes from the city, where these developments are already commonplace, he feels that he knows the future of the Appalachian Pentecostals. He places himself further along in the timeline of development.

Richard feels unable to talk to the Pentecostals because he does not view them as equals. Instead, Richard relies on his interactions with Rife. Richard seeks out Rife's company in an effort to find "the more genteel citizens of Black Rock" (121), and Rife 
seems to fit the bill. Rife, like Richard, was not born in Appalachia. He has been living in Black Rock for thirty years, overseeing a church that is slowly dying. Also like Richard, Rife "was educated at a University" (122). Most importantly, he distinguishes himself from "primitive . . . carnival emotionalism" of Appalachian churches, especially Pentecostal ones which practice "revivals and snake-handling and foot-washing and speaking in tongues" (122). Instead, "he is clearly fascinated by these practices and by these mountain people" because he has "an entire desk containing 'notes' he has made [on them] over the years" (122). Still, Rife's interest in Appalachian Pentecostals is different than Richard's. For Rife, they are simply intriguing subjects. For Richard, they hold the key to a more vibrant spirituality that modern society has lost. Richard brings his observations and struggles back to Rife and often includes Rife's thoughts about the events he describes in his journal. Meanwhile, the people of the Pentecostal church remain lower subjects which only warrant description in terms of "the worn faces of these hard-working home-bound women” (138), “toothless jack-o'-lantern grins” (139) "flailing arms and legs" (154), etc. The "stench" of their poverty, their lack of education, and their "primitive" behaviours keep Richard from fully engaging with them.

Dory replaces the Pentecostal church as Richard's primary method for exploring the primitive spirituality that Appalachia has to offer. Richard retreats to his makeshift room in the school house with Dory and they spend days having sex. Richard describes the two as "enclosed here, as in God's womb (intriguing image!) ... It is a veritable new world! which corresponds, needless to say, to the state of my soul" (156). Richard believes he has found, finally, the natural impulse toward religion he has been searching for. As the two meet and "couple like animals" (158), Richard asserts that he has "passed 
beyond believing in retribution, beyond morality as [he has] known it, beyond belief in any God but the mountain God who traffics not in words and acts but in the heart" (162). Although Dory says very little, she has provided him with a way to push past his modern reservations which kept him from being fully involved in the Pentecostal church. This connection, of course, does not last. Having shirked his duties as a school teacher and turned the school house into a love nest for him and Dory, the people of Black Rock fire him, forcing him to return to the city. He wants to bring Dory with him, but Dory's sister orchestrates their breakup. Richard leaves distraught, while Dory, unbeknownst to Richard, has his children and remains broken hearted. Many critics focus on Richard's failure in his relationship with Dory as representative of the educated outsiders' failure to relate to the Appalachian people; they cannot see past the stereotypes. Martha Billips, for example, argues that Richard "fails to see her [Dory's] full humanity" (40), which underlines "the difficulty outsiders often have in seeing beyond their essentialized conceptions of Appalachians" (37; also see Jones 107-10; Wallace 367-68). For these critics, Richard's interactions with the Pentecostal church become simply another metaphor for Richard's inability to meet the Appalachian people on their own terms. In the context of the rest of Smith's work, however, the treatment of Pentecostals in Oral History becomes the beginning of a pattern which portrays them as the true "contemporary ancestors" in Appalachia, unable to function in the contemporary world because of their commitment to an outdated, immature, ecstatic religious tradition. 


\section{Karen and Pentecostalism as Childhood Interest}

"Tongues of Fire" is a short story originally published in Smith's 1991 collection Me and My Baby View the Eclipse. It is a kind of bridge between the outsider deconversion narratives of Covington and Richard and the coming-of-age deconversion narratives of Barnes, Perry, and as we shall see, Smith's novel Saving Grace. Karen is a thirteen-year-old who feels "invisible in the midst of [her] gorgeous family" (10). Immediately after describing her sense of invisibility, Karen says "perhaps it is not surprising that I turned to God” (10). Karen attends a Methodist church with her grandparents and, less frequently, members of her immediate family. Karen describes the members of the church as "so old as to be almost dead already" (11). The services consist of "dull responsive readings ... [and] rote mumbling of the Nicene Creed" (12). This is not enough to make her visible in her family. By contrast, she fantasizes about being "seized by God for His heavenly purpose, bent to his will as in God's Girl, [her] favourite book - a biography of Joan of Arc" (12). Karen's “obsessive reading” provides her with a dramatic imaginary world which she prefers to her invisibility in her stuffy upper-middle class family, but none more so than the biography of Joan of Arc. She imagines that the wilder Baptists across the street from her grandparent's house have something close to the dramatic Joan of Arc style spirituality she longs for. She sits “on her grandparent's front porch for years eating pie and envying the Baptists ... they wore loud suits, and made more noise in general than quiet Methodists" $(12,11)$. Furthermore, if the Baptists across the street represent a step toward a more vibrant spirituality, then the churches further out in the country with unclear denominational affiliations represent a step even further. Like Covington and Richard, Karen imagines that the charismatic churches of 
Appalachia hold an ancient, more engaged spirituality that more urban congregations have lost.

These churches, however, have a very clear social ranking that Karen's mother explains:

Methodist at the top, attended by doctors and lawyers and other "nice" families ... of course, at the very bottom of the church scale were those little churches out in the surrounding country, some of them recognizable denominations (Primitive Baptist) and some of them not (Church of the Nazarene, Tar River Holiness) where people were reputed to yell out, fall down in fits, and throw their babies. (12)

Karen does not fully understand all of what her mother says, but she does know that she would "love to see" one of the lower class churches. Karen falls prey to an exoticization of the lower class which extends beyond religion. She envies a classmate Tammy who is "shunned by Sub-Debs, sent to detention, admired by older boys ... [lives] out in the country someplace (in a trailer, it [is] rumoured) ... and best of all she [is] missing a tooth right in front" (16). Unlike Karen, Tammy "had not read any books at all, and did not intend to" (37). Karen recites these attributes to explain why she "admired Tammy Lester more than any other girl in [her] entire class" (16). In other words, Karen's desire for a lower class church experience is tied to her envy of the lower classes. Fortunately, as Karen learns, Tammy is able to provide access to both the lower class and Pentecostalism since Tammy's family attends a rural Pentecostal church. The two girls play a modified version of The Prince and the Pauper, where Karen slums it with 
Tammy's family and Tammy experiences a taste of the upper-middle class life while eating pie on the porch with Karen.

Karen's involvement in the church remains just as superficial as Richard's involvement in a Pentecostal church. Initially, the idea of hearing Tammy's mother speak in tongues enchants Karen. When she finally does, Karen has a moment of recognition: “Tammy's mother ... opened her mouth and screamed out in a language like none I had ever heard, yet a language which I felt I knew intimately, somehow better than I knew English. It was my language" (27). It is the language of Joan of Arc which she has been longing to hear and speak. Tammy's mother becomes a model for Karen in her pursuit of dramatic spirituality. Step one, for her, is to get saved and baptized, which she does the following week. The experience leaves her feeling "wet and holy" and she repeats the experience the following week despite her mother's objections (32). In fact, Tammy notes that getting saved and baptized two weeks in a row is unusual, but Karen ignores her. She is on a personal quest which supersedes the objections of participating Pentecostals. In fact, just like Covington and Richard, Karen draws attention to the pastor's language in order to distance herself from the congregation and assert her superiority. The preacher's name is Mr. Looney, casting the Pentecostal church as not only lower class but also “crazy.” Looney looks like George Gobel, an American comedian who capitalized on a simple rural persona (25). He speaks "in a monotone with a hick accent" (25) and punctuates "his sentences with an 'Ah!' at the end of each line," reminiscent of the way Covington represents Punkin Brown's speech (26). If Karen does not see the class difference between herself and the Pentecostals until she leaves the 
church, her mother notes it immediately and ends Karen's involvement, at least temporarily, by sending Karen away to summer camp.

At camp, Karen continues her exploration without the assistance of the Pentecostals. It is an Episcopal camp, and Karen finds the weekly services just as "boring" as Methodists services, causing her once again to fantasize about Joan of Arc (35). While lying in bed sick one afternoon, sunlight fills the room and she hears a male voice she assumes to be God say her name. She reasons it is God not only because the voice does not match any of the males at the camp, but also because she is "filled with His presence, and [she] knew what [she] must do" (30). She goes immediately to the assembly hall and starts "speaking in Tongues of Fire" just as she had witnessed Tammy's mother do earlier (39). This is not the first time that Karen appears to jump to conclusions about the next step of her spiritual journey. Earlier in the story, she lights small fires around her neighbourhood. She describes this practice in the same paragraphs where she describes beginning to "pray a lot (without ceasing [is her] intention)" (15). There is no overt explanation for the fires, although there seems to be an unspoken link to the Tongues of Fire she speaks later in the story. She abandons the practice of lighting fires soon after attending Tammy's church for the first time as the attendance at church appears more exciting, more dramatic. Karen finds her experience of speaking in tongues equally disappointing. After several days under close observation in the infirmary, she rejoins the rest of the camp, where everyone treats her "with a lot of deference and respect" (40). When she returns home from camp, her country club friends mock her experience, and rather than be offended, she enjoys the dubious celebrity: "I was famous all over town ... I began to feel popular and cute, like the girls on American Bandstand" 
(41). This appreciation quickly replaces the conviction that she "had been singled out for some terrible, holy mission ... like Joan of Arc" (40). Speaking in tongues has made her visible, and she capitalizes on that visibility, eventually abandoning her sense of "holiness, of [her] chosenness" (43). Like so many of Karen's experiences in the story, hearing the voice of God and speaking in tongues disappoints her, and she quickly moves on.

The story frequently repeats Karen's pattern of anticipation, followed by intense involvement, which is then quickly replaced by disappointment. Karen is initially surprised at how much she likes the summer camp her mother sends her to. The sense of history offered by the "old camp" gives her "an enormous thrill, as did all the other traditions" (33). Chief among these is the selection of a "Camp Spirit," a special camper who gets to light the camp fire that campers sit around and sing songs. By the second week of camp, however, her enchantment already begins to fade (37). By the final week, she is "really tired of singing" (40). She is selected to be the Camp Spirit, but the selection is "an anticlimax" (40). Likewise, Karen finds horses and horse-riding disappointing. Before she goes to the camp, she loves reading "anything at all about horses" (13). While she initially looks forward to going on trail rides at the camp, when she finally rides a horse, she does not "like the horses nearly as much as she'd expected to. For one thing they were a lot bigger than [she] had been led to believe by the illustrations in [her] horse books. . . For another thing they were not loveable either. They were smelly, and some of them were downright mean" (34). Finally, Karen "always wanted a kitten" (40), but when her mother gives her one, partly as a bribe to stay at camp, it is "a disaster ... Sandy [the cat] mewed too much, not a sweet mewing, but a 
little howl like a lost soul ... He didn't act like a cat” (41). Once again Karen is disappointed that the reality does not live up to her expectations. The pattern points to Karen's unrealistic and childish expectations. In this context, then, her experience with the Pentecostal church becomes just another immature experiment of a child.

Karen, however, does grow up. When she returns from camp she gradually begins to accept her role in the upper-middle class, bolstered by the new celebrity afforded to her by her speaking in tongues. She goes to a movie with her sister and a group of older teens. She joins "the Gifted and Talented group for English and French" at school and joins the cheerleader squad (43). One evening, she discovers Tammy half naked, embracing a boy. She is startled, and her reaction to the revelation is telling. She hears the echo of her class-conscious mother in her mind saying "a nice girl does not Pet" (42). "Nice," as illustrated earlier, is not simply a descriptor of ladylike behaviour, but also of class. Karen is not shocked by any kind of moral compromise which Tammy might be engaged in, something which would taint her Pentecostal practice and belief. Instead, Karen is suddenly reminded that Tammy is simply not of her class. It is not long after this experience that Karen abandons her desire for a dramatic spirituality entirely. If there was any doubt as to how she views Pentecostal experience, it is cleared up in the final paragraph of the story. Without the drive for a holy, Pentecostal purpose, she is free to pursue the life of an upper-middle class woman: "Now ... I would make cheerleader, and go to college. Now I could grow up, get breasts, and have babies. Since then, all these things have happened" (43). Continuing her pursuit of a more dramatic spirituality in the Pentecostal church, among the lower class people of the country, would have delayed her growth into the woman she currently is. While she admits that she occasionally catches 
herself "listening for that voice" she hears at the camp, the voice she once thought to be God, the dichotomy is already clear: she can either pursue the wild Pentecostalism of the mountains or she can be a functioning member of contemporary society. It is a dichotomy which plagues Smith's depiction of Pentecostals in her interviews and her fiction, especially Saving Grace.

\section{Losing Grace}

Smith's novel Saving Grace is unlike her other fictional portrayals of Pentecostals in that it is, at least partially, a coming-of-age deconversion narrative. Florida Grace is the daughter of a snake-handling Pentecostal preacher who spends much of her childhood travelling from town to town. Yet Grace, like Barnes, Perry, and others balks at parts of the religious practices and beliefs internally. In the novel, however, Grace does not leave home and her religion at age 18. Instead, she is abandoned by her father at age 17 and marries another Pentecostal minister, Travis Wood. It is not until she is in her mid-thirties that she finally leaves Travis, her children, and her religion behind to pursue an affair with a younger man. While the affair does not have the same disastrous effects that Barnes's relationship with David does, it ends in disappointment for Grace. This leads Grace to a kind of revelation at the end of the novel, albeit an ambiguous revelation that has spurred much critical controversy. The novel, then, is the first person recollections of Grace on the edge of this revelation. Jacqueline Doyle argues that, as with many conversion and deconversion narratives, "Grace seems to retrace her life with a particular spiritual goal in mind that determines her perspective on past events" (276). This is very much in line with Barbour's understanding of deconversion narratives, where the reasons 
for rejecting the old religion point to the values inherent in the new religion or ideology, even if the new religion or ideology is not discussed. At several points, Grace's "postconversion hindsight" invades the narrative. These moments, combined with details from the ending, suggest that Grace returns to her Pentecostal roots at the end of the novel. While the novel does leave open the possibility that this Pentecostalism will be adapted and more gender friendly, there is still a sense that it is a failure. This sense is a result of the tension in the narrative between the reasons for rejecting Pentecostalism in the first place, and the reason for return. In the end, Grace is lost on the wrong side of the dichotomy that Smith sets up regarding Pentecostals, the dichotomy between "good" and "bad" religion.

Virgil Shepherd, Grace's father, represents the "bad" side of the dichotomy. He is an impulsive, snake-handling, Pentecostal preacher who has trouble staying faithful to his wife. Like Barnes's father, Grace's father is the face of the Pentecostalism for his daughter. In fact, as many critics have noted, he is very clearly linked to God as well (see Eckard Maternal 178; Doyle 277; J. Hall 92; Amende 86). At one point, Grace says "whenever I pictured God, especially the God of the Old Testament who parted the Red Sea and sent boils to people and burned up Sodom and Gomorrah and smote His enemies dead, I pictured Daddy with his white hair and his sharp eyes and his deep lined face" (28). This association not only bolsters his position as "the master in [the] house" (28) but also leads Grace to privately resist God and Pentecostalism in her youth. Near the beginning of the novel, she says "I did not love Jesus. And I actually hated Him when $\mathrm{He}$ made us take up travelling in His name, living with strangers and in tents and old school busses and what have you" (4). Of course, the directives of where and when to travel 
come via Virgil. Virgil does not adhere to a strict theology, but instead thinks "long and hard about the Bible and [draws] his own conclusions" (18). Elsewhere, Virgil says "I am follering the plan of God just as he reveals it to me day by day. I ain't going to quibble with Him, nor split hairs. I ain't a-going to say, 'But away back there in Exodus, Lord, you said such and such'... I ain't about to question Him” (92). This allows Virgil to justify his behaviour and decisions based on shifting theological notions. Grace says "I never knew what to expect from Daddy and anything might be true. Anything" (70). While Barnes's father partially redeems himself by teaching Barnes to think and reason, albeit in a limited form which she eventually surpasses, Virgil actively and willingly shirks rational thought in favour of what Smith represents as wild, mountain Pentecostalism.

Virgil not only exhibits the kind of irrational, and ultimately irresponsible religion that Smith condemns, but is able to entice others to participate in it as well. Grace attributes this largely to her father's voice. Grace says “Daddy had a deep, ringing voice and spoke real slow, so that every word he said registered, and seemed to settle directly on the soul ... not like most preachers, who will yell at you and shame you and try to make you feel bad. Daddy's voice made you feel good, like you were strong in the Lord and proud to do His will" (17). Amende notes that Virgil's voice, as Grace describes it, has a seductive quality (87). In various places, Grace says his voice "made you want to do whatever he said" (18), "would not take no for an answer" (21), and "made everything true" (29). The impact is clear on Grace. She is initially undeterred by the possibility of going to hell as a result of contradicting her father, but when she is faced with the opportunity to escape him into an adoptive family, it is "his voice" that makes her want to 
follow him (116). Virgil's seductive voice overwhelms her rational objections and replaces them with an excitement, and an overwhelming impulse to follow. Grace is not the only one who falls prey to Virgil's voice. He uses it to draw people into his church, to bring them up to the altar to be saved, and eventually to convince them to take up serpents. Virgil's apparent miraculous displays in taking up serpents, drinking poison, and healing the sick only add to the attraction people feel toward Virgil. Grace says "people were drawn to Daddy like bugs to a flame. He had something they wanted, and they'd stick around to find out what it was" (16). Like the flame, Virgil can be dangerous for those he attracts. For example, in a large meeting, several people are bitten by snakes and one of them dies. No one seems to suffer more than Grace's mother, Fannie.

Fannie meets Virgil when she goes to a Pentecostal service in a tent. Initially she goes to make fun of Pentecostals. At that point she is a "dancing girl" whose husband has just passed away, leaving her with three children. Grace says "she had no one to turn to . . . she was down real low when she met Daddy. She didn't care about anything, not what she did, nor what happened to her. She was mad at the world" (23). Like many others who hear Virgil speak, Fannie is smitten by Virgil and returns for several more services. One night, Virgil notices her and kisses her as he is being arrested for handling snakes. When he is released, they leave town together with Fannie's children, Grace's halfsiblings. Grace is convinced that Fannie deeply loves Virgil; Grace sees a "light that [comes] to her face whenever he [speaks]" (116). It causes Fannie to follow her husband's impulsive decisions, including those based on what he believes to be God's direction, as well as abiding by Virgil's rigid understanding of gender roles. According to Virgil, "a woman can handle [snakes] and she can preach but she can't decide things" 
(99). The result is that Fannie is "often like one of [the] kids" next to the authority of Virgil in the home (28). This presents severe restrictions on her behaviour, which Grace only sees traces of. When Virgil is away, Fannie paints her toenails (113) and plays dress up with the children (12). In fact, she is generally more permissive with the children when Virgil is gone. Grace, however, understands the threat of Fannie going against Virgil, especially when he arrives home unexpectedly to find Fannie wearing makeshift jewelry: "we [Grace and her siblings] were scared, we didn't know what he meant to do" (17). Virgil ends up kissing Fannie, making her giggle, but the incident demonstrates the power imbalance between Fannie and Virgil, and the potential for violence which reinforces that imbalance. The imbalance manifests itself in other ways. Since Fannie is unable to decide things, she must endure the consequences of Virgil's decisions. Though Virgil looks "like a workingman" (74), he is not employed throughout most of the novel. He also does not take up offerings at meetings, instead relying on the unprompted generosity of those in his congregation (17-18). This practice, combined with his tendency to travel frequently, for long periods of time, leaves Fannie to find ways to stretch the meager resources of the family to meet the needs of the children. The responsibility takes a visible toll on Fannie. Grace says there is a "frequent sadness in her pale grey eyes and [a] shadow that sometimes [falls] on her face" (13) and her "eyes [are] always red from crying" (49), especially when Virgil plans a dramatic demonstration like drinking poison, or a long trip. Things finally break down when Fannie discovers Virgil's infidelities. A young woman visits Fannie to tell her about the affair, and Fannie confronts Virgil, who confesses and asks for forgiveness. While Fannie forgives him (at least on the surface) and he moves on to continue his preaching, something is broken in 
Fannie. Grace says she becomes a "witchlike stranger" while the "sweet loving mama [is] gone by then, and gone for good" (88). It is not long after this that Fannie hangs herself. Grace speculates that Fannie has had her own infidelities, and that is part of the reason why she hangs herself. However, as Grace sits beneath her mother's lifeless body and kisses her painted toenails, "the only trace of that dancing girl from long before," (113) there is a sense that Fannie is driven to suicide because she has sacrificed herself and her decisions for love of Virgil, which he has betrayed.

Virgil's lifestyle also has several more subtle effects on Grace. The first is that the economic condition of the family creates a cultural gap between Grace and her peers based on class. At various points in the novel, Grace wishes she was "a regular girl from a regular family" (41). For Grace, to be "regular" means having a middle-class lifestyle and the accompanying possessions. She wishes her father would apply his seductive voice to sales so that she and her siblings could have "decent school clothes at least, but [Virgil says] he [can] not afford to waste his time studying on the things of earth. Jesus [won't] let him" (17). Grace clearly sees the family's poverty as a direct result of Virgil's religious conviction: one can either be poor and follow God's will, or be middle class and "regular." Grace makes a similar distinction later in the novel: "I didn't want to be a special servant of the Lord. I didn't want the keys to His Kingdom either. I wanted a pony, or at least a bicycle" (30). A pony or bicycle seem like innocent desires which do not correspond with class, however, when put in the context of the other things she envies of her schoolmates, such as "a nice brick house" (4), "radios" (4), "a shelf full of books" (46), "a television set" (46), it points to the way that the family's economic condition creates a cultural gap between Grace and her classmates. This is evident in her interaction 
with a particular classmate, Marie. Grace says "I wanted Marie's whole life, right down to her underwear" (53). This includes Marie's family house: "She lived in a white brick ranch house with grass in the yard and a picture window that bowed out from the living room and had about a million little panes of glass in it. Inside, the entire house looked like a magazine with everything matching" (45). By contrast, Grace sees her own house as "so poor . . like a picture book about olden times" (46). The poverty of Grace's family is not only a result of the religious conviction, but an indication that the family is antiquated and anachronistic. Virgil and his family occupy the position of contemporary ancestors normally assigned to Appalachian people in general in relation to Marie's more advanced family.

Material possessions and economic resources are not the only thing that makes Marie's family more advanced. They are also well educated. Marie's mother is an artist with a home studio and a "strange hard Northern voice," while Marie's father is a college professor who is "at home reading a book" when Grace arrives to visit for the first time (45). They both encourage Marie's creativity as well as her school work. Virgil, meanwhile, won't let his children "read anything except for the Bible, he [says] that was all [they] needed to read" (11). The prohibition on reading includes "the newspaper, as the only news [they] needed to know was the good news of the Gospel" (11). Of course, he allows the children to attend school where they do read books other than the Bible. However, he makes clear to his children that school is not important. Grace's education and grades suffer, not only because she is teased as an outsider due to her clothing, school supplies, and unusual religious practices, but also because Virgil pulls her out of school on a regular basis to take "care of Troy Lee [her youngest sibling] or [pray] over those 
who were sick or had gotten bit" (41). For Virgil, the demands of God's work take precedence over education, and Virgil's lack of encouragement regarding education leads to Grace's waning desire to go to school. At one point, she only goes to school because her (supposed) half-brother Lamar insists. ${ }^{32}$ When Grace tells him she would rather stay home with the family, he responds, rather prophetically, "that's just what you think right now. That's just what you think today ... they's another day coming" (83). While that day does come, it is too late. When her mother commits suicide, her father pulls her out of school and they travel from town to town preaching. Grace never finishes high school, and both the lack of education and ability to make rational choices limit her after her father is gone.

Grace's father abandons her in order to pursue a relationship with a woman he meets in a church service. Rather than return to Scrabble Creek, where she could live with concerned neighbours who had already taken in one of her sisters, Grace feels that she has "come too far along the road that [she is] on, to turn back now. [She has] to keep going on" (150). Instead, she works at a local diner and stays in a trailer belonging to the owner of the diner. She sees this as the first step toward asserting her own independence: "I had big plans right then. I hoped it would not be very long before I could save up enough money to get some kind of car myself. The I would drive over to Scrabble Creek for a visit before heading out for parts unknown, where I would get a job and make my fortune" (151). Although Grace has grown up in a family which downplays material possessions and the acquisition of wealth, she has been exposed to material wealth through her classmates and equates it with independence and the opportunity to pursue a

\footnotetext{
${ }^{32}$ Lamar tells Grace that he is Virgil's son, but hides this from Virgil. After Lamar disappears, Grace is unsure if he was telling the truth about Virgil.
} 
fortune. The plan, however, does not last long. In a moment of reflection, she admits "I was young, and thought I could do anything, and have it all" (151). When the owner of the diner demands sexual favours she realizes that she cannot continue to work there. She has no financial resources, and no place to live, and her inadequate education leaves her with few options. This lack of options is ultimately what prevents her from following the coming-of-age deconversion model that Barnes and Perry follow. Her situation seems worse than that of her mother's when she meets Virgil for the first time. Like her mother, however, Grace marries an older Pentecostal minister who shows up to save her.

Within minutes of being accosted by the owner of the diner, Travis Word knocks on the barricaded door of her trailer. Like Virgil, Travis "look[s] like a man from another time" and is "against progress in every way" (210). There are, however, some important differences between Virgil and Travis. Before Virgil abandons Grace, Travis initially accepts both him and Grace into his church, "which had been declining," because Virgil could "get folks jacked up, laughing and shouting in the Spirit, full of joy" (138). Virgil's behaviour, however, leads the church to discontinue the practice of snake-handling when he leaves. While Virgil is often swayed by his emotions and frequently "backslides" into affairs, Travis shows "restraint" and "control[s] his emotions" (168). Grace comes to see this as indicative of Travis's "certainty, his faith, his strength" (168); Travis as a "real saint" not a "plaster saint like Daddy" (197). Travis takes Grace home to live with him and his three sisters. Eventually the two marry despite the large age gap between them (Travis is 42 while Grace is 17). At this point, Grace still has "not been saved" (166). Like her mother who "loved Jesus ... [but] loved Daddy more" (24), Grace is "more 
interested in Travis than in God" (166). As it turns out, this is only Grace's first step toward becoming like her mother.

By the time Grace is in her thirties, and a mother of two girls, she finds herself unhappy in her role as a house wife for a pastor. She comes to this realization while standing outside the house where she and Travis live: "somehow I could not go inside, where there were beds to be made and dishes to wash and everything else that I had been doing every day for the past fifteen years" (213). Although Travis's steady income does not present the same challenges that Virgil's sporadic income and spending presented for her mother, Grace finds herself stuck in a role where she has no control over the decision making process. While Travis can occasionally be persuaded, the frequent presence of Travis's sisters bolsters a gender divide. Anytime Grace challenges Travis, or expresses an interest in doing something for herself like get a job, "all those dark Words eyes would turn in [her] direction ... Minnie's mouth harden[s] into a line, and Vonda Louise start[s] biting her lip like she always [does] when she got nervous" (207). In fact, the sisters seem to be a constant pressure on her to conform to the role of a good wife, illustrated from the very beginning of the marriage by giving her Minnie's wedding dress to wear. Things come to a head for Grace when she is visiting an elderly woman who grabs her hand and says "Listen to me. Get out of here" over and over (203). Though the woman could have meant anything, Grace worries that she "might turn into a mean old woman like that [her]self. In fact [she] thought [she] was in danger of doing so immediately ... [she] felt as old as the hills. [She] felt ungrateful, and mean, and old" (203). This is due in no small part to the fact that she realizes she has "never been able to act like I wanted to, in all my life" (184). Like her mother, her choices have been limited by her lack of financial 
resources, her inadequate education, and the relationships she has with men. What sustains Fannie is the excitement she experiences with Virgil, which makes her blush in public and "call out in a way [Grace] cannot account for" at night (14). This is simply not the case with Grace and Travis. Kathaleen Amende argues that Grace marries Travis "to escape carnality" because Travis is reserved not only in his emotions, but also in sex (92). Each time the couple have sex, Travis kneels down to pray for repentance. He also resists Grace's advances after they are married. The problem with Amende's argument is that Grace does not recognize Travis's aversion to sex until after they are married. She seduces him into the marriage by stripping in front of him, and brags at one point that she does "something to him that had him down on his knees until dawn" (198). Grace does not marry Travis to escape from carnality, but rather because he presents himself to her as a stable contrast to her father at a time when she has few other options. Travis's aversion to sexuality means that Grace becomes dissatisfied in her marriage much more quickly. Things only get worse when Travis slips into a depression following a still birth. Grace says "I wanted to run around and act up and smash things" (200). It is at this time that Randy Newhouse comes into her life.

Randy represents the excitement that Grace is missing in her life with Travis. A few years younger than Grace, he comes to do renovations on the house and Grace is instantly attracted to him. She says "while Randy was at the house, I got what Mamma used to call the 'all-overs'” (217). This not only signals her desire for Randy, but also connects it to the excitement her mother feels with Virgil. When he secretly calls her on the phone, his voice sends "an electric shock through [her] whole body," once again linking Randy to Virgil. She eventually begins an affair with him and says she has "more 
energy than [she has] ever had, [she is] sizzling with it;" the experience makes her feel "born again" (225). When Travis's sisters discover the affair and inform Travis, Grace leaves him and her daughters to live with Randy. This is the moment of her deconversion. Throughout her description of the affair, Grace insists that it is her responsibility: "it was all my own doing, and all my own fault" (217); "I had caused this myself, by looking out the window for him [Randy] the way I did" (224). Even when she looks out the window, however, she describes feeling compelled not only to look out the window, but to go down to see him: "I just had to" (217). Elsewhere, she captures the tension more fully: "I had struggled with this decision. I had tried to struggle" (22). Framing her affair with Randy as a decision implies an agency which she immediately undermines by saying she "tried to struggle." A few lines later, she undermines her agency even more: "I was going to do what I was going to do long before I even knew I was going to do it" (223). Her affair with Randy is something she is drawn to do, and in spite of her claims of choice, her descriptions are reminiscent of the descriptions of her first sexual experiences with Lamar (before her mother commits suicide) as well as her spiritual experiences. In fact, in the tent meeting during which Fannie hangs herself and people are bitten by snakes, Grace feels compelled to participate in the service: "before I knew it, I found myself standing and clapping with the rest ... I felt the Spirit running through me like a grass fire ... I felt self-conscious, like I had been caught with my clothes off' (105). Grace describes her spiritual experiences, especially ecstatic ones, as something she begins to do before she realizes, something she gets carried away in, much the same way Richard and Karen describe their experiences. Immediately after this description, Lamar appears at her side, and the two slip away to have sex: "I was swept along, carried away in the 
general fever of that night" (106). This is only the most explicit instance where Grace links sexual and spiritual ecstasy, much like the others in this dissertation. In this case, however, it illustrates the way Grace frames her involvement in both as being swept away. Despite her claims to the contrary, her initial experience with Randy represents a continuation of this sense of being swept away. Randy provides her with the possibility of excitement she has not experienced since she was in Scrabble Creek.

The excitement, however, does not last. As Grace begins to show signs of age, Randy begins an affair with a younger woman. When Grace confronts him, he says that she should have known better: "it's normal. But you're not normal. You never were normal" (241). Randy's sentiments are in keeping with his admiration of "free love" which Grace says “sounded like some of Daddy's theories to me" (232). Grace finds herself in the position of her mother again, even though she is not affiliated with a church. As she says on two different occasions, she has "given up everything for Randy Newhouse" (244; also see 239) and now he has betrayed her by having an affair, just as her mother gave up everything to be with Virgil only to have him betray her. Randy's argument that Grace is not normal also draws in something else that he says to her frequently. On other occasions, he says Grace has "been living in a time warp" (224), or "living under a rock" (232). Randy is not the only one who notices that Grace is having trouble adjusting to the world outside "old timey" Pentecostalism. Her daughter, who is on the verge of completing nursing school, encourages her to seek counselling with "plenty of other women who have dealt with these same problems" and get "some other kind of job where you don't have to dress up in an outfit" $(251 ; 243)$. Grace, however, becomes convinced that she is "not real good at modern life" (239), and her failed 
relationship with Randy is just part of that. She is only qualified to be a waitress, and currently must wear a period costume at her job. The costume provides an important contrast as she sits in her "Olde English outfit" watching Johnny Carson but "can’t understand any of the jokes, it was like it was all babble in another language or something" (240). While Barnes and other characters are able to bounce back from damaging and abusive relationships after leaving Pentecostalism, Grace simply does not have the education or financial resources. She is stuck in a "time warp" which leads her back to Scrabble Creek, and ultimately, to church.

On her way back to Scrabble Creek, Grace meets a former member of her father's church. He invites her to attend a service, but she declines. Still, the invitation sticks with her. She returns to the house of her childhood, where she is writing her memoirs. The tense abruptly shifts from past to present as Grace finally describes her salvation. Lying in her parents' old bed, she hears her mother whisper to her: "Come to me, Gracie, she says. Oh come to Jesus honey. It is time now, it is never too late" (269). Grace's response is, at first, "I have always minded Mama" (269). A few lines later, echoing her mother's whispers, she says "I believe I will go to church today. I believe it is time" (270). Once again prompted by the voice of her mother, she sheds the jeans she brought with her and puts on one of her mother's old dresses. Still too early for church, Grace sits by the fire when she says:

The Spirit comes down on me hard like a blow to the top of my head and runs all through my body like lightning. My fingers and toes are on fire. Oh Lord it is hard to breathe and I am so scared Lord, I am so scared but I will let my hands do what they are drawing now to do and it does not hurt, 
it is a joy in the Lord as she [her mother] said. It is a joy which spreads through my body, all through this sinful old body of mine. (271)

Here, Grace is describing handling hot coals as her mother does near the beginning of the novel. While Grace is initially disturbed by watching her mother do something which could potentially harm her, she now realizes the joy that comes from it when the Spirit/the Lord prompts her. Taking up the coals, as Grace describes it here, is not a rational decision, but rather a relinquishing of rational thought, an abdication of agency to God, and it is clearly the Christian, Pentecostal God of her childhood. She finally follows in the footsteps of her mother, taking up the coals and even wearing her mother's clothes. As she leaves the house to go to church, she says "everything is black and white up here today" (271). Grace sees her life as one of resistance to God's will, and now that she has given in and finally become saved, now that she has converted, things are much clearer for her. Not only that, but she has a feeling of euphoria: "there was nothing to be afraid of after all and I am happy Mamma, I am" (272). At the end of the novel, Grace takes one last look at the house at Scrabble Creek as she leaves for church, beginning a new life as a committed Pentecostal woman.

Despite the overt indications that Grace returns to Pentecostalism at the end of the novel, readers have struggled to understand what happens and have come up with wildly different interpretations. Paula Eckard says that when she teaches the book in her classes, "some believe that Grace has been reborn spiritually and will now, for better or worse, follow her parents' religious practices. Others fear she is preparing to commit suicide like her mother" (189). Eckard, meanwhile suggests that "Smith contrasts male-dominated Christianity and Western thinking with more mythic, immanent, female ways of 
knowing" (Maternal 176) and that Grace "find[s] a meditation between matriarchal and patriarchal spiritual realms" (Maternal 187). Likewise, Doyle suggests that Grace finds "a radically revised Christian spirituality that is open ended, indeterminate, mysterious, and woman-centred" (275) which embraces the "maternal sacred" (280). ${ }^{33}$ Linda Byrd Cook takes this one step further and argues that Grace finds a form of goddess spirituality (161). Amende argues that these readings are "premature" but empathizes with the sentiment which drives them: "readers want to believe (at least this reader did) that the playful and sensual physicality of the mother can combine with the religion of the father to create a healthy heterotopic space for Grace, but without further understanding of her mother's life it may be impossible for Grace to carve out such a space, and she may simply end up returning to a way of life that killed her mother" (45). Although a grim contrast to the bright, happy optimism which Grace reports at the end of the novel, this is the reading that is most supported by the text.

Grace's judgements throughout the novel support reading Grace's epiphany at the end of the novel as a return to traditional Pentecostalism. As mentioned earlier, she writes her story while she is in her parent's old house, just before she leaves to go to church. Her judgements, then, largely reflect her perspective at that point, as a journey that leads up to her Pentecostal salvation. Both Amende and Doyle see this as the persistent impact of her father's religion. Amende argues that while Grace "rebels" against Virgil she "still believe[s] that his doctrines were correct ... Grace, despite believing that she has traveled far from her father and his church, has never actually left it" (93; also see Doyle 275). What both critics miss is the subtle difference in the theology implied by Grace's

\footnotetext{
${ }^{33}$ Rebecca Smith has a similar reading (186).
} 
judgements and that of her father. Grace says her father believes "a person could go out and do whatsoever they damn well pleased, and then could repent and get forgiven for it, over and over again" and she "never really believed that that was the case" (165). Instead, at the end of the novel, Grace believes that "God will bring every deed into judgement, with every secret thing, whether good or evil" (270). This is a variation of Ecclesiastes 12:14 which Travis quotes earlier in the novel. In fact, Grace says his theology comes "closer to [her] own" (165). Travis "place[s] works above grace in order of importance" (164). It is from this perspective that Grace judges her father as a "plaster saint" (197), someone who does "everything too much" (51; also see 91). Travis meanwhile is a "real saint" (197), "a good man" (262). Grace does not critique Travis's patriarchal approach to marriage or the place of women in the church. Instead, she characterizes leaving him as a "the worst sin a woman can commit" (222). Grace does not reject a theology which condemns her departure from a smothering marriage into sexual exploration; she embraces it and condemns herself as a sinner. Grace brings a works-based theology to the Pentecostal church and integrates it with ecstatic practices like snake-handling and handling hot coals. If she also wants to make room for a more female centred spirituality in her father's old church there is no indication of it in the text.

Even if she does, the novel hardly celebrates her decision. Grace's sunny optimism at the end of the novel is an uncomfortable contrast to the novel's position on her religious conversion. To return to the snake-handling church, Grace must retreat from the modern world into an anachronistic religious community. She must give up her ability to make decisions for herself and rely on the men around her, who have wildly inconsistent theologies that accommodate their whims rather than those of the women 
around them. She must give up rationality in favour of ecstatic experiences which leave her prone to manipulation. She must embrace poverty, ignorance, and most importantly, an unfulfilled life. The novel does not present Grace's return to Pentecostalism as a victory but as a tragedy; at the end of the novel, Grace is not saved, she is lost in the wild Pentecostalism of Appalachia.

\section{Could Have Been Her}

If there is some ambiguity about the way Saving Grace ends, Smith says it is unintentional. In fact, at one point she tells a friend that perhaps she should have made the ending more obvious (J. Hall 91). For Smith, Grace unequivocally returns to the Pentecostal church of her childhood without introducing any feminine spirituality. In an interview with Susan Ketchin which appears in the "Reader's Circle" edition of the novel, Smith compares Grace's journey to a character in a prodigal storyline; "Personally, I didn't want [Grace] to do this," says Smith "but I think it is what she would have done" (282). Smith determines what Grace would have done by drawing on a part of herself she tends to suppress. In another interview with Charline McCord, Smith says "I have this orderly kind of life, you know. And yet here is wild, haunted Grace running around. I think she's another part of myself that never has a voice in the real world ... These are experiences I would never have. This is a person I wouldn't ever get to be, if I hadn't been able to write that book" (89). Smith frames the novel as a way of exploring Pentecostalism from a safe distance, a Pentecostalism she rejects because she has enjoyed upper-middle class education and opportunities which have trained her to be a rational, neoliberal individual. 
Smith's wild, haunted Grace becomes much clearer when Smith talks about her childhood involvement with Pentecostalism, which echoes that of Karen in "Tongues of Fire." Smith calls that story her "most autobiographical" because it so closely mirrors her own life (Christ-Haunted 45). "I loved Joan of Arc, and I loved these inspirational stories like Karen does" she tells Ketchin (Christ-Haunted 46). Also like Karen, she had a friend whose family attended a Pentecostal church that seemed to offer her the opportunity to live a life similar to Joan of Arc. "I was just wild for this family," she says. "I would have gone to live with them if I could ... I just loved the 'letting go' that happened when I would go to church with my friend" (45). Smith's involvement in Pentecostal churches lasted much longer than Karen's. Smith says when she was older she began attending a different church with her boyfriend at the time: "I would go to the revival with him and be saved — constantly" (45). For Smith and her boyfriend, going to services acted as a kind of foreplay merged with religious ecstasy. "Religion and sex-you know, excitement, passion—were all together," she says. "I couldn't differentiate between sexual passion and religious passion. This is what we did on dates, was go to the revival. It was a turn-on" (45-46). Smith says she even believed she heard the voice of God while at summer camp (53). Meanwhile, Smith's mother, like Karen's mother, did not approve of her daughter's involvement in the Pentecostal churches. "She wished I would quit going to these other churches and 'acting up,"' says Smith. "You know, it was a 'lowclass' thing to do in my mother's eyes" (46). As a result, Smith ended her involvement in the church in the same way Karen does: her mother sends her away, only in Smith's case, it was not to a summer camp but to an Episcopalian boarding school. It is there, Smith says, that she "outgrew it [Pentecostalism]; I got interested in other things. It was one of 
those things of childhood" (47). Elsewhere, she adds "the younger you are, the more intense your feelings are" (Cook "Spiritual" 74). Pentecostalism, for Smith, is something she participated in as a naïve girl with intense feelings. Like Karen, her attention drifts from her superficial participation in the church to something else while she is separated from the Pentecostal churches. As a result, Pentecostalism appears infantile and childish. She uses a coming-of-age frame to display spiritual disposition which firmly positions her as neoliberal and modern, just like her target audience.

Smith says she is thankful her mother forced her to grow out of Pentecostalism, in spite of her ongoing fascination with what she calls "very dramatic, more compelling kinds of religion" (McCord 89). Her fascination is more removed than in her youth, she explains: "as you get older that sort of thing scares you because there are not any boundaries. It was terrifying" (Christ-Haunted 47). Although she does not clearly distinguish them, there are two elements about Pentecostalism which scare her as an adult. The first is the notion that she will lose herself in the ecstatic experiences themselves: "the reason I'm terrified is because of the loss of identity. I mean, if you give yourself over completely in this mystical sense, then who's left? Who are you?" (Mississippi 89). This loss of identity, which simultaneously attracts and repels Barnes, Fox, and Covington, has practical components for Smith. "As an adult you have to be responsible," she tells Ketchin. "You know, I can't be transported. I have to go to the grocery store." Ketchin adds "I have to be back by three to pick up the kids" and Smith agrees: "I can't have a religious experience; I have to be back by three. All of these people are depending on me" (Christ-Haunted 48). For Smith, Richard is a cautionary tale in this regard. She describes his spiritual quest as an effort to "become less 
'Episcopalian,' to loosen up" (53). Richard's departure from Black Rock, even if it is not entirely his own decision, saves him from permanently losing himself according to Smith. "It's the notion that if you loosen up too much, if you become too spiritual, you go nuts" she says (53). While there is still a romanticized longing in Smith's description of Pentecostalism, Smith depicts those who practise Pentecostalism as irresponsible individuals who are unable to feed themselves or provide for their own children. Pentecostalism, then, becomes a phase, a passing interest that responsible adults set aside.

The second component that scares Smith involves a surrendering of choice. This is clearly connected to the first element. To lose oneself during religious experience is to abdicate one's ability to choose. "That is both compelling and desirable, and terrifying, to me," she tells Peter Guralnick. "Then you don't have to make any decisions—ever" (151). This surrendering of choice is not solely related to ecstatic experience, she explains: "It's that desire to affiliate, you know, that terror of being on your own and thinking that you shouldn't be on your own. I mean it's easier to do what you are expected to do and get with the group that will tell you what to do" (150). There is additional danger Smith sees as a woman drawn to Pentecostal churches in Appalachia: "the primitive church that had turned me on so much as a girl, well, they put down women" (Christ-Haunted 50). While both men and women are susceptible to manipulation because they abdicate their choice when joining a Pentecostal church, women must follow restrictive gender roles which dictate what they wear, if/where they work, and what positions they can hold in the church. Appalachian churches also teach "salvation by grace," which Smith says "seems like another way of justifying frontier hedonism — for men only, that is, not for women. It seems like much of that kind of 
religion was instituted by men and conspired to hamper women" (54). Smith's interpretation of the theological notion of salvation through grace lacks an awareness of its centrality to most Protestant churches that frequently condemn the kind of hedonism Grace's father engages in throughout Saving Grace. Instead, it is based on her limited interaction with Appalachian Pentecostals themselves. This interaction leads Smith to conclude that the cost of becoming a Pentecostal is simply too high when compared to its rewards. Though she might experience spiritual ecstasy and take comfort in not having to make decisions, she would give up her ability to function independently in the contemporary world while subjecting herself to the whims of men in the church. As a mature, neoliberal adult, she cannot accept a decision to remain involved in Appalachian Pentecostal churches as a rational, self-interested choice, so she maintains her fascination at a safe distance. Smith walks the line between attraction and repulsion much better than Fox; although Smith expresses a longing for ecstatic religious experiences, she immediately explains what is wrong with those experiences, and why she does not indulge in them.

Researching snake-handling Pentecostals allows her to maintain that distance while indulging in her fascination. This is precisely what she does while working on Appalachian Portraits with photographer Shelby Lee Adams. Smith and Adams travelled around Appalachia interviewing and photographing residents, including members of a snake-handling Pentecostal church. Smith fictionalized the interviews in a series of short vignettes which appear at the beginning of the book, including one called "Ludie Royal" about a female snake-handler. The first-person narrative describes the ecstatic sensation of handling a snake during a service. Smith tells Ketchin that this vignette, and Saving 
Grace, were largely inspired by a woman she spoke to while working with Adams. The woman told her "when you've had the serpent in your arms, the whole world takes on an edge for you" (Saving Grace 218). At first, Smith reacted as a journalist, appreciating the line as a great quote. This reaction was followed by what Smith describes as having a "sense of recognition ... except for the accidents of family and circumstance, I could have been her" (280). Smith says she spoke to other women "who had grown up in the church [and] left it the first chance they got; they literally fled from it. But, once they were in the outer world, if things didn't go well, sometimes they'd come back ... People often go back to what they know, whether it is good for them or not. Like a child who wants to return to an abusive family" (281). Later she says that these stories are really about "the helplessness of children — something that bothers me profoundly-how children are so often born into difficult or dangerous situations over which they have no control, and how those childhoods can affect them forever" (286). Smith casts all of the women who choose to return to Appalachian Pentecostal communities as helpless, abused children, unable to make rational choices. Smith explicitly states "this is what happens to my Grace" (281). At this point, Smith explains that Grace returns to the Pentecostal community because of "her lack of education and experience. Her lack of options" (281). What prevents Appalachian Pentecostal women from leaving the church for good is their lack of education, experience and options - their inability to function as rational, selfinterested, neoliberal subjects. The "accidents of family and circumstance" which save Smith from a similar fate are her class conscious mother who sends her away to boarding school combined with her advanced education. Without them, she would be a helpless 
child whose growth as a rational individual is stunted by perpetual spiritual ecstasy and abusive father figures in the church.

Smith's assessment of women's position in Appalachian Pentecostal churches does not take into account the complexity of gender relations within those churches. Based on her field research, Shauna Scott argues that there is a tension within the church surrounding gender. On one hand, "Pentecostalism ... reinforces patriarchy by depicting women as 'weaker vessels' and commanding them to remain 'under submission' to men" (229). On the other hand, Scott argues that "the religion appears to challenge patriarchy by offering expanded spiritual roles to women, as healers, prophets, and preachers. Worship practices emphasize emotional, spiritual release and expression, behaviours typically associated with femininity, and Pentecostals view women and men as spiritual equals who are judged by God according to the same standards" (229). The two sides of this tension do not necessarily balance each other out as "male preachers greatly outnumber women; and when women do preach, they frequently find their spiritual gifts are devalued and their personal authority undermined" (229). Despite this, Scott suggests that the Pentecostal church is much more a site of "ideological struggle" (229) in terms of gender, where women are not helpless and abused, but rather struggle to assert themselves.

In Sheila Collins's oft cited essay "Theology in the Politics of Appalachian Women," she calls on women within various churches to resist patriarchy by telling their stories:

Theology begins with our stories: what we do with our time; how we feel about our families, our friends, our coworkers, our bosses; how we feel 
about money and who gets it; what we do when we get up in the morning; how we make it through the day; what pains us, enrages us, saddens and humiliates us; what makes us laugh; what enlightens and empowers us; what keeps us holding on in moments of despair; where we find separation and alienation; where we find our true community and trust. Nothing that is of us can be alien to our theology. (152)

For Collins, it is not only the content of women's stories, but the quantity. As more women within a particular church share their different stories, the church will be forced to respond. Again, this paints a picture of a Pentecostal church in which there is room for struggle, resistance, and ultimately change, where women have both voice and agency, very unlike the Pentecostal church that Smith describes. Ironically, both Jacqueline Doyle and Paula Gallant Eckard cite Collins in order to describe what Grace does in writing her story (Doyle 275; Eckard Maternal 175). For them, the hope that Grace represents is a church with women who openly share their stories without flinching from sharing their anger, their desire, even their despair, leading to a church that responds to those stories. It remains an optimistic reading of the novel, but points to a kind of potential for change within Pentecostal churches that Smith does not acknowledge.

For Smith, the only hope for Grace is that she will leave the church again and instead adopt something closer to Smith's neoliberal spirituality. She tells Ketchin "I like to think that by now, Grace has had enough of it [Pentecostalism] and she's gotten herself some peer counseling in Knoxville, and a good job someplace, not in a bar" (Saving Grace 281). Grace need not abandon her spiritual activity, but rather try to strike a balance where she is able to participate in some kind of spiritual pursuit without it taking 
her over; a balance between having a community but not allowing it to remove her ability to make rational, self-interested choices. This is the kind of spirituality Smith strives for, the kind of spirituality she sets against Appalachian Pentecostals in her interviews. While Smith has attended both Episcopalian and Unitarian churches, she, like Covington, Richard, and Karen, finds they both lack the kind of spirituality she yearns for. Instead, she finds this "more 'religious,' more intense" spiritual experience outside of church (qtd. in Cook "Spiritual" 75). She compares her own spirituality to that of a character in a different novel, Ivy from Fair and Tender Ladies: "she is unable to find a religion that suits her-an organized religion. So she makes up her own" (Christ-Haunted 51). Nature is an important part of Smith's customized spirituality, as is "reading poetry, reading Thoreau, reading the kinds of things that put you in nature" (qtd. in Cook "Spiritual" 75). More than nature and reading about nature, however, writing provides something close to a Pentecostal experience: it is "a way to get in touch with that intensity, a way of getting in touch with and staying true to me. I do feel, when I'm writing at a fever pitch, that intensity that you feel when you get saved. There's nothing else that makes you feel like that. There's getting saved, sex, and writing" (Christ-Haunted 51). Smith draws on her upper-middle class education to construct a spirituality that allows her to experience the "intensity" of Pentecostalism in a contained, and even productive environment, much like Barnes describes her writing practice. Whereas Appalachian Pentecostalism, for Smith, is populated with women who are unable to make rational choices because their growth as neoliberal subjects is stunted by a primitive, patriarchal religion, Smith is able to make rational, self-interested choices about her religious practices because of her upper-middle class education and experience, along with the options her upper-middle class upbringing 
afforded her; she is able to find a spirituality which helps her get in touch with herself and stay true to herself, a spirituality which helps her produce her own fulfilment.

In her interviews, Smith is able to straddle the line that separates Perry and Fox. Like Perry, she has a very clear coming-of-age deconversion story: as a young child, she participates in a Pentecostal church for a short time but grows out of it. At the same time, like Fox, she expresses a certain longing for the ecstatic experiences of Pentecostalism, even sexualizes them. Unlike Fox, however, she clearly presents her reasons for not participating in Pentecostalism. In fact, when she talks about Saving Grace and her interviews with snake-handlers, she occupies a position very similar to Stephen Marche. Like Marche, she stands alongside readers to look at the Pentecostal others, poor, abused victims who returns to their abusers because they do not see any other option. Smith does not objectify the women as sexual mysteries the way that Marche objectifies Fox. Instead, she expresses a condescending sympathy for Pentecostal women. Positioning Pentecostals as others aligns her with readers who share her neoliberal sensibility when it comes to religion. She strengthens her affective bond with her readers be reproducing Pentecostal stereotypes and displaying the proper spiritual disposition toward them and her Pentecostal past.

\section{Covington and Smith}

A review of Smith's Saving Grace in the Washington Post suggests that in spite of Grace's "miscalculations" in her religious and romantic decisions which make her a "refugee from one bad dream to another," the novel is "a redemptive work of art" (X01). The reviewer goes on to say "the novel has a grand and singular purpose, to clothe the 
spirit with flesh. In this, Lee Smith succeeds. Saving Grace is lucid in execution, breathtaking in scope and heart-rending in effect" (X01). The author of this review is none other than Dennis Covington. It is no mistake that Covington reviews Smith's novel so favourably. Smith also provided a blurb for Covington's memoir: “Salvation on Sand Mountain is a scary and brilliant book, beautifully written. Covington has a strong ear for dialogue. He understands and articulates the strong appeal of this no-holds-barred, allfor-nothing, hard old faith in a surprising and memorable narrative" (qtd. in Covington i). This is more than a quid pro quo exchange of positive reviews between authors and friends. It points to a similar approach that both authors have toward the snake-handlers of the southern Appalachian Mountains. Both authors are drawn to the dangerous, mysterious "no-holds-barred" ecstatic activities of the snake-handlers. At the same time, both decide that the cost of being a snake-handler, including the risk of death, adopting the oppressive theology, shunning the contemporary world, and living in poverty, is "allfor-nothing," especially for women. Both authors try to make something "redemptive" out of their experience with the Appalachian Pentecostals, something that will help them, and possibly others see the "spirit" in a new robe of flesh, which one can comfortably view from an educated, middle class environment. In so doing, however, they end up supporting stereotypes of Appalachian snake-handlers which portrayal them as anachronistic, immature, and poor, and often helpless members of a "hard old faith."

Smith's fiction is even further removed from the anthropological and sociological ethical guidelines that Covington's memoir fails to satisfy. She does not tell the stories of the people she interviews, but rather uses the stories of interview subjects as inspiration for her own stories. As a result, there is no clear link between her characters and the 
people she interviews, aside from inspiration. There is a certain creative freedom which Smith enjoys, allowing her to project parts of herself on to characters which may have no counterpart among the women who are actually part of snake-handling communities. This creative freedom, however, does not excuse her for perpetuating a stereotype about a group of people in her fiction. Furthermore, her more blunt and inflammatory characterizations of the actual snake-handling women enhance those stereotypes as a contrast to Smith's more "enlightened" neoliberal spirituality. In other words, Smith's writings about Appalachian Pentecostals, though they are fictional, have as much potential to do damage as Covington's memoirs.

The impact of Smith's fiction is too broad and varied to accurately measure; however, two pieces of anecdotal evidence point toward the kind of damage it can do to the disadvantaged community of Appalachian snake-handlers. A review of her book in Publisher's Weekly suggests "Smith has great empathy for the poor, uneducated country people who yearn for a transcendent message to infuse their lives with spiritual meaning" (185). The empathy that the review describes is laden with condescension and seems to call for the kinds of missionary projects that Whisnant derides. The snake-handlers are not a contemporary group of people who have a unique and complex religious practice in a region that has been exploited for its cheap labour and natural resources; they are poor, uneducated, country people who need a bizarre, anachronistic religion to give their lives meaning, and deserve our sympathy. The review enhances the stereotypes Smith draws upon in the novel, like the reviews of Covington's memoir amplify the stereotypes in his book. Snake-handlers themselves reacted to those stereotypes with anger. Smith recounts a story about an Appalachian woman who attended several readings, and finally angrily 
approached the author, accusing her of mocking snake-handlers. Smith dismisses her as missing the point of the novel (D. Brown 301). Smith, in turn, may miss the impact of what she has written.

Smith's writing does engage in the kind of creative self-definition that Cunningham calls for in what can easily be read as a manifesto for Appalachian writers. As a resident of southern Appalachia, she writes fiction about what it means to be from and live in Appalachia. More importantly, what it means to live in Appalachia is not the same for all of her characters. Smith is able to provide a multivalent depiction of Appalachian people which captures some of the diversity of people from the region. In so doing, she resists the stereotype that suggests all Appalachian people are poor, ignorant, uneducated, and stuck in the past. She celebrates different forms of folk knowledge, most of the time without the condescending romanticization that has plagued much of the writing about Appalachia. The exception is her writing about Appalachian Pentecostals. They are the contemporary ancestors who live in poverty and ignorance, who are governed by archaic theology and gender restrictions. Their isolation from modernity may allow them a greater immersion into ecstatic spirituality, but it is an immersion, Smith determines, whose cost is too high, not only for her, but for all women who remain in the church. Smith may challenge stereotypes that group all Appalachian people together as archaic and childlike, but she reserves Appalachian Pentecostals as a group of people who continue to function as an other. 


\section{Conclusion}

\section{The Potential of Pentecostal Deconversion Narratives}

This dissertation began as a celebratory extension of John McClure's postsecular literary theory. As mentioned earlier, McClure focuses on fiction that "trace[s] the turn of secular-minded characters back toward the religious" (Partial 3). These characters do not transition "from worldliness into well-ordered systems of religious belief" but instead end up in "ideologically mixed and confusing middle zones in the conversion narrative" (4). These middle zones embrace manifestations of the supernatural and the possible existence of spiritual realms without attempting to fully define the supernatural or the spiritual. This dissertation sought to study Pentecostal deconversion narratives that feature protagonists and communities that already accept dramatic, even chaotic manifestations of the supernatural on a regular basis. These protagonists would turn away from these religious traditions toward the secular without fully embracing secularity. Like postsecular protagonists, they would end up in "ideologically mixed and confusing middle zones in the conversion narrative" (McClure 4) where they would experiment with different practices and beliefs in an attempt to combine their new "secular" ideas and desires with the residual religiosity they take with them when they leave Pentecostal communities. Essentially, they would arrive at the same postsecularism that McClure describes, but come from the opposite direction.

The deconversion narratives in this dissertation do show some of this potential. The most obvious example is Dennis Covington's treatment of snake-handling. Covington never dismisses spiritual or supernatural explanations for what he experiences while handling snakes. In fact, it is an experience which makes him more attuned to the 
supernatural and spiritual all around him. Barnes and Smith use speaking in tongues as an analogy for what they experience when writing, framing their writing as a similar religious experience. Their descriptions of writing, however, tend to downplay the supernatural, if not dismiss it altogether, while maintaining a vague, spiritual sensibility regarding their writing practice. Barnes also suggests that her religious upbringing, despite its limitations, did provide her with some important stepping stones to becoming a functional, contemporary woman. Specifically, Barnes's father teaches her the principles of rational inquiry, which eventually enable her to make clear, rational, and ultimately self-interested decisions regarding her life and spirituality. Similarly, Perry suggests that the performance aspects of Pentecostalism helped prepare her to become a pop star. In both cases, there is little that is supernatural or spiritual. More importantly, each of these efforts to creatively blend a Pentecostal past with a secular sensibility seem like anomalies when set against the critique of Pentecostalism and stereotypical representations of Pentecostals themselves which permeate these narratives.

The deconversion narratives in this study represent Pentecostalism as irrational, ignorant, oppressive, narrow-minded, and anachronistic. Pentecostals themselves are represented in two different ways, normally gendered. The men tend to be manipulative and authoritative. Barnes's father, Perry's father, and Grace's father restrict the activities of their daughters in ways that the narratives represent as extreme and irrational. Likewise, the male leaders of the snake-handling church that Covington attends are authoritarian and inflexible in ways that Covington presents as anti-modern. Grace's father is even worse. Not only are his rules more extreme and more restrictive, he is a hypocrite who fails to live up to his own strict standards. By contrast, the narratives 
represent Pentecostal women as subservient, constrained, and ultimately victims.

Barnes's mother and Grace's mother both sacrifice career goals, beauty products, and, more importantly, their own autonomy to become Pentecostal wives. Both are ultimately unfulfilled as a result of these choices. Covington, meanwhile, draws attention to the restrictive gender roles of the snake-handling churches, though his representations of the women are not quite as detailed. Restrictive gender roles often work together with the exilic tendencies of Pentecostals. These tendencies lead Pentecostals to restrict access to cultural material, like music, literature, and movies, while downplaying the importance of education. Barnes, Perry, Karen, and Smith draw attention to the fact that Pentecostal girls have fewer options in the long term as a result. While all four women leave Pentecostalism as a result of these restrictions, Grace provides the best example of how the restrictions impact women long term because she does not leave soon enough. As a result, she has few financial or career options, and has very little experience with social interactions outside the church. With limited options, she makes several poor decisions because she is not equipped to make rational, self-interested choices. This is why Smith compares her to an abused child who returns home because she seems to have no other option. Of course, these representations of Pentecostalism do not take into account the complex, and diverse kinds of Pentecostals and Pentecostal experiences that exist in the United States, nor do they acknowledge the nuanced gender negotiations which happen within Pentecostalism. Instead, these narratives reinforce stereotypes about Pentecostals. Many of these stereotypes are not restricted to Pentecostals, but extend to Evangelicals in general. One way to expand this study would be to broaden the scope to look at Evangelical deconversion narratives. What separates Pentecostalism from other 
Evangelical denominations is the emphasis on ecstatic religious experiences, a seemingly irrational, emotional experience which the authors in this study suggest leave one vulnerable to manipulation. Nonetheless, there are many similarities between Pentecostalism and other Evangelical denominations. Baptist denominations, for example, often share many of the same conservative theological positions as Pentecostals, as well as the same perceived connection to conservative politics. More importantly than these similarities is the fact that many representations of Evangelicals in popular culture seem to gloss over differences between denominations or even congregations. The tendency is to represent Evangelicals in general as narrow-minded, authoritarian, and regressive, especially when it comes to gender roles. An examination of a variety of Evangelical deconversion narratives would provide an opportunity to see which of these stereotypes extend across all denominations, and how denominational particularities manifest themselves. ${ }^{34}$

Of course, these stereotypes extend beyond deconversion narratives. Movies, television shows, political cartoons, and contemporary fiction are all filled with stereotypical representations of Evangelicals. John Weaver has already written extensively on how stereotypes of Evangelicals appear throughout the $20^{\text {th }}$ century in both literary fiction and popular culture. Christopher Douglas, meanwhile, is currently working on a project called If God Meant to Interfere: American Fiction During the Conservative Christian Resurgence, which examines the way contemporary American literary fiction by authors like Marilynne Robinson, Philip Roth, Barbara Kingsolver, and

\footnotetext{
${ }^{34}$ David Hempton's book Evangelical Disenchantment begins some of this work, but his most recent example is James Baldwin. A study of contemporary narratives which include middlebrow and popular culture narratives would provide a more complementary extension of this dissertation.
} 
Cormac McCarthy misrepresent Evangelicalism and its resurgence as a political force in the United States. A study of Pentecostal stereotypes would complement these projects by situating Pentecostal stereotypes in relation to Evangelical ones, drawing attention to both similarities and differences. As mentioned earlier, these ecstatic religious experiences become the epitome of irrational, overly-emotional, "bad" religion, yet as the coverage of Meagan Fox illustrates, there is still an attraction to them as exotic, and ultimately erotic, experiences. A study of Pentecostal stereotypes in contemporary American culture would explore the ways this exoticization and eroticization of Pentecostal experience coexists with a depiction of Pentecostals as rigid, inflexible, conservatives.

All of these further studies will need to address the way liberal and neoliberal approaches to religion enable and encourage Pentecostal and Evangelical stereotypes. As discussed in Chapter One, there is a long history of liberal Protestants stereotyping conservative Protestants as a ways of distinguishing the two and privileging the liberal side. This practice has continued through liberal spirituality and into neoliberal spirituality. It is ironic given the celebration of pluralism within liberal and neoliberal spirituality. It quickly becomes clear that this pluralism does not include conservative Christians. In the contemporary period, the exclusion and stereotyping of conservative Christians may have more to do with the anxiety surrounding the association of religion with conservative theology and politics. Authors and celebrities in this study "other" Pentecostals in order to emphasize that the spirituality to which they belong is rational, autonomous, and progressive. A similar othering of Evangelicals is widespread in popular culture. In part, this othering helps reassure target audiences that authors and 
celebrities are not conservative, irrational and religious, but rather rational, progressive, and spiritual; authors and celebrities enhance and affective relationship with their audience by demonstrating that they share the same spiritual disposition as their audience. This othering is problematic because of the way it perpetuates stereotypes, but it becomes increasingly problematic with the turn to neoliberal spirituality. More work needs to be done in studying the way neoliberalism manifests itself within religious activity labeled as "spiritual." A starting point might be "spirituality" books. "Spirituality" eclipses "New Age" as a genre of books in the mid-1990s, around the same time neoliberal ideas of the self become much more common, and when Oprah dramatically changes the focus of her television show. A closer study of the content of these mid-1990s books, along with attention to the way older books are marketed differently during this period would help reveal the contours of neoliberal spirituality and identify it as an important part of understanding the way neoliberalism redefines classic liberal terms with a market inflection.

\section{The Gains and Losses of Deconversion}

What would a deconversion narrative that does not stereotype and other former religious traditions look like? Michelle Syba asks a similar question in a 2013 article for the online magazine Killing the Buddha. "What if we had different kinds of stories of faith lost today, beyond the usual narrative of rationality trumping emotion?" "“At the Judgement"). While the narrative of rationality trumping the overly-emotional, irrational religious activity of Evangelicals, Pentecostals in particular, is widespread, Syba focuses on the deconversion narratives of new atheists. For example, Jerry DeWitt's 2013 
memoir Hope After Faith tells the story of the former Pentecostal minister's transition to a public atheist. For DeWitt, it is his depth of research and rationality that lead him to dismiss faith and embrace atheism. Syba wants to resist both the stereotyping of Evangelicals as well as the valorization of rationality. Instead she calls for deconversion narratives that do something different: "The reason-trumping-emotion story is too easy, not true enough to the complex of losing (or gaining) faith... We need more kinds of stories of faith lost or reconfigured ... stories about the kinds of emotions possible before and after faith" (At the Judgement"). As an example, she offers her own story.

Syba was raised as a Pentecostal and left during her twenties. While she was still a teenager, she became concerned that she "never felt the ways an evangelical should ... [she] was not adequately enthusiastic about Jesus' sacrifice for humankind" ("At the Judgement”). Later, she explains "I didn't thrill at the idea of Jesus conquering Satan once and for all in the End Times to inaugurate a new and perfect world. The thought of God creating my best friend down to her pinky toe and mapping out the stars did not stir great awe. The strongest feeling Christianity stoked in me was anxiety. Anxiety that I couldn't feel in the right ways and was therefore damned" ("At the Judgement"). It is this anxiety, not rationality, that causes her to leave: "I simply got tired of trying to be moved. Growing up in a religious culture that emphasized interiority and authentic feeling, I found the pretense too exhausting to sustain for a lifetime" ("At the Judgement"). Once she leaves Pentecostalism, she does not experience "an efflorescence of rationality, but instead new kinds of emotion" (“At the Judgement”). Instead of anxiety over her own salvation, she experiences awe and wonder about seemingly mundane events like meeting a new friend. "For me, losing faith had little to do with rational argument" she says ("At 
the Judgement"). In so doing, she not only presents an alternative to rationality trumping emotion deconversion narrative, she also clearly individualizes the deconversion narrative. For her, deconversion meant replacing anxiety with awe, but it might not be that for everyone. It is this personalization which influences her depiction of Pentecostals. For example, Syba talks about her attempts to ignite her own awe and gratitude toward God while she was still a Pentecostal. At one point, this meant responding to altar calls in her church on a regular basis. She tells the story of someone coming to pray for her while she is at the altar. The person who prays for her tends "to be an older woman of British descent, sinewy and upbeat, with a taste for georgette" (“At the Judgement”). Syba tells the woman about her anxiety and, although the woman is surprised, she listens to Syba sympathetically. The woman then prays for Syba and gives "a stern rebuke to the devil. 'You leave this young lady alone!"” (“At the judgement”). Syba relates similar exchanges with her Sunday School teacher. The women in her story are not oppressed, subservient victims. Instead, they are the only authority figures in the church that Syba depicts. They are sensitive, sympathetic elders who try to help her. They also show no signs of sharing the doubt and anxiety that Syba suffers from. Syba does not use her experience to generalize the plights of all women in the Pentecostal church. Instead, her anxiety and doubt are hers, and her reasons for leaving do not apply to these women. Syba's understanding portrayal extends to her mother in an earlier article for Killing the Buddha called "Pentecost in Mexico." In this article, she describes a vacation she takes with her mother in Mexico, during which they are mugged. Syba prefaces the event by describing her mother as "fantastically nonjudgmental. When I moved in with my partner, she never expressed disapproval. When abortion comes up in conversation, 
she expresses sorrow but affirms the woman's right to choose" ("Pentecost"). Already, Syba's portrayal of her mother resists some of the stereotypes surrounding Pentecostals. This does not mean that her mother does not believe in things like evil spirits and the power of prayer. Syba admits that those beliefs sometimes cause her discomfort. When her mother talks about demons, Syba assumes "a posture of slouching skepticism and embarrassment" which she imagines her mother "should feel for believing in demons in the twenty-first century" ("Pentecost"). Syba goes on to say "I wish the demons were a lively metaphor but they're not" ("Pentecost"). Despite her discomfort, Syba finds common ground with her mother, and even an appreciation for her mother's Pentecostalism, the same Pentecostalism Syba has rejected: "Faith has allowed my mother to see possibility where others would have seen a cramped predicament. Faith has been a salutary adaptation, supplanting fear with courage, an initiation into a braver life" ("Pentecost"). While Syba can no longer share her mother's beliefs, she acknowledges the way it has made her mother braver and stronger, rather than weaker. Syba's mother is not a victim, thanks in part to Pentecostalism.

Syba's appreciation of her mother's strength and bravery does waver, especially when the two are mugged. When a man points his pistol at the women and demands their money, Syba takes comfort in her rationality: "I would rather not die, I thought. It was a strong preference, reasonable, a refusal of pure terror ... I didn't have the certitudes of a seer, but I had something better, rationality" ("Pentecost"). Of course, Syba's comfort in rationality is only a pretense which quickly crumbles. "The barrel of his pistol was now agitated," she says. "In my mind, I hear the pistol go off ... Here was the end of 
rationality. Here was terror" (“Pentecost”). Syba's mother, meanwhile, does not seem quite as shaken, and instead, begins to speak in tongues:

my mother who began to speak, her voice confident and aggrieved, the cadence steady, the volume louder than anything the man had used on us. Her words were foreign to me, as they were to the man, in a language only Jesus and the Holy Spirit could understand ... She sounded like she was indignantly reading a Greek menu, uttering syllables like taramosalataspanakopitamoussaka! ("Pentecost”)

Though Syba does add a rather humorous description of glossolalia as "indignantly reading a Greek menu" her mother does not surrender her autonomy, leaving her vulnerable to manipulation. This is an empowered act of resistance. Later, her mother tells her "II refused to submit to the evil that is in them ... That evil would have power over me, to harass me"” ("Pentecost"). Initially, Syba is angry with her mother for inciting the man's anger. While he yells at Syba's mother, he does not hurt them. By the time she is writing the article, however, the anger has dissolved into appreciation for her mother's strength, even if it is somewhat dangerous.

Earlier in the article, Syba describes residual Pentecostal feelings which she experiences from time to time. While walking in the town in Mexico, before she is mugged, she says she had "a vestigial feeling that everything would be ok, that God would keep me safe ... even though I do not particularly believe in God. The old Pentecostal habits of feeling overwhelm my intellectual wiring and my liberal brain short circuits" ("Pentecostal"). This habitual feeling disappears when she is confronted by the thief. She falls back on rationality, but that eventually fails, leaving her in a state of 
terror. Her mother, meanwhile, remains brave and strong in the knowledge that there is more going on than a man with a pistol taking her money. In leaving Pentecostalism, Syba not only escapes her anxiety, she also gives up a source of comfort and strength which empowers her mother to resist becoming a victim in the face of a man with a pistol. Syba's deconversion is not simply a matter of development, which places her new liberal secularity on a point further ahead of her mother's Pentecostalism. Instead, it is a matter of gains and losses; she focuses on "the kinds of emotions possible before and after faith" (At the Judgement"). Syba gains freedom from anxiety and access to feelings of awe and wonder but loses an empowering sense of the divine which enables a different kind of bravery and resistance. Syba does not evaluate these gains and losses according to a neoliberal model, which requires one to place a value on what is gained and what is lost in order to calculate which option is more profitable in terms of her self-fulfilment. Instead, she acknowledges that deconversion is not simply a matter of growing into one's self, of maturing and progressing along a linear development of religious practice, of gaining freedom and independence - it is also an experience of loss.

At one point, Syba says "I like to think that I am a different kind of secular liberal, one whose value for tolerance and pluralism includes evangelicals" ("Pentecost"). There remains in this statement a privileging of her liberal secularity. Likewise, when Syba acknowledges the benefits of her mother's faith, they are practical benefits which someone can embrace from a secular position; she does not accept her mother's appeals to the supernatural, whether it be demons or divine intervention. This kind of privileging seems, to a certain degree unavoidable in deconversion narratives. A deconversion is, after all, the story of an individual's choice to reject one worldview in favour of another; 
if the individual did not prefer the new worldview to the old, he or she would not have switched in the first place, and that preference is bound to present itself in a deconversion narrative. Nonetheless, there is a self-conscious way in which Syba expresses her preference. She acknowledges what she loses in her deconversion, she acknowledges the limits of her liberal secularity, she personalizes her reasons for leaving rather than projecting them on all the practicing Pentecostal women around her, and she avoids stereotyping the women. Perhaps she does not experience the same anxiety as those who practice liberal and neoliberal spirituality; she does not feel the need to differentiate her religious practices from conservative Christians because she has no religious practice that might be confused for conservative Christianity. Nor does she promote a rigid scientific rationality against religion in the way of new atheists like DeWitt and Richard Dawkins. Instead, she is conscious of the particularity of the women who practice Pentecostalism and attempts to bridge the gap between herself and those women, especially her mother. Her mother, in turn, reciprocates and makes an effort to bridge the gap as well. Syba's deconversion narrative does not realize all the potential that this dissertation set out to find. She does not attempt to incorporate spirituality or the supernatural in her own, newly secular world view. At the same time, she is able to present her narrative in a way which does not perpetuate stereotypes about Pentecostals; she presents them as thoughtful, strong individuals facing some of the same difficulties in the contemporary world as she does. 


\section{Works Cited}

Abbott, Lee K. "Death Rattle.” New York Times Book Review 9 Apr. 1995: 14. Print.

Abel, Elizabeth, Marianne Hirsch, and Elizabeth Langland, eds. The Voyage In: Fictions of Female Development. Hanover, NH: UP of New England, 1983. Print.

Adams, Shelby Lee and Lee Smith. Appalachian Portraits. Jackson: UP of Mississippi, 1993. Print.

Amende, Kathaleen. Desire and the Divine: Feminine Identity in White Southern Women's Writing. Baton Rouge: Louisiana State UP, 2013. Print.

Anderson, Dana. Identity's Strategy: Rhetorical Selves in Conversion. Columbia: U of South Carolina P, 2007. Print.

Asad, Talal. Formations of the Secular: Christianity, Islam, Modernity. Stanford: Stanford UP, 2003. Print.

Awad, Isabel. "Journalists and Their Sources: Lessons from Anthropology." Journalism Studies 7.6 (2006): 922-39. Print.

Azzopardi, Chris. "The Many Dimensions of Katy Perry." Between the Lines 5 July 2012: 15-16. Print.

Babington, Charles and Darlene Superville. “Obama 'Christian By Choice': President Responds To Questioner." huffingtonpost.com. Huffington Post, 29 Sept. 2010. Web. 16 Mar. 2014.

Bachleda, F. Lynne. "Keeping Faith with the Earth.” Publishers Weekly 241.7 (1994): 36. Print.

Barbour, John D. Versions of Deconversion: Autobiography and the Loss of Faith. Charlottesville: UP of Virginia, 1994. Print. 
Barnes, Kim. Hungry for the World. New York: Villard, 2000. Print.

---. In the Wilderness: Coming of Age in Unknown Country. New York: Anchor Book, 1996. Print.

---. Interview by Robert Root Jr. Fourth Genre: Explorations in Nonfiction 2.1 (2000): 170-90. Print.

---. "Prayer, Piety, Passion, and Prose." kimbarnes.com. N.p., n.d. Web. 05 May 2013.

Barnett, Tully. "'Reading Saved Me': Writing Autobiographically About Transformative Reading Experience in Childhood." Prose Studies 35.1 (2013): 84-96. Print.

Barnhart, Joe. The Southern Baptist Holy War. Austin: Texas Monthly, 1986. Print. Beaman, Lori. "The Myth of Pluralism, Diversity, and Vigor: The Constitutional Privilege of Protestantism in the United States and Canada." Journal for the Scientific Study of Religion 42:3 (2003): 311-25. Print.

Bellah, Robert N., Richard Madsen, William M. Sullivan, Ann Swidler, and Steven M. Tipton. Habits of the Heart: Individualism and Commitment in American Life. Berkley: U of California P, 1985. Print.

Belletto, Steven. No Accident, Comrade: Chance and Design in Cold War American Narratives. New York: Oxford UP, 2012. Print.

Bennett, Tanya Long. I Have Been So Many People: A Study of Lee Smith's Novels. Dahlonega: U of South Georgia P, 2014. Print.

Bernard, H. Russell. Research Methods in Anthropology: Qualitative and Quantitative Approaches. Lanham: AltaMira, 2011. Print.

Bibby, Reginald. Fragmented Gods: The Poverty and Potential of Religion in Canada. Toronto: Irving, 1987. Print. 
Billips, Martha. “'What a Wild and Various State': Virginia in Lee Smith's Oral History.” Journal of Appalachian Studies 13.1-2 (2007): 26-48. Print.

Billings, Dwight, Mary Beth Pudup, and Altina Waller. "Taking Exception with Exceptionalism: The Emergence and Transformation of Historical Studies of Appalachia." Appalachia in the Making: The Mountain South in the Nineteenth Century. Ed. Mary Beth Pudup, Dwight Billings, and Altina Waller. Chapel Hill: U of North Carolina P, 1995. Print.

Birckhead, Jim. “'Bizarre Snake Handlers': Popular Media and a Southern Stereotype.” Images of the South: Constructing a Regional Culture on Film and Video. Ed. Karl Heider. Athens, GA: U of Georgia P, 1993. 163-89. Print.

---. "Snake Handlers: Heritage, Salvation, and Celebrity in the '90s." Appalachian Journal 23.3 (1996): 260-75. Print.

Blond, Philip, ed. Post-Secular Philosophy: Between Philosophy and Theology. New York: Routledge, 1998. Print.

Boone, Kathleen. The Bible Tells Them So: The Discourse of Protestant Fundamentalism. Albany: State U of New York P, 1989. Print.

Booth, Wayne C. "The Rhetoric of Fundamentalist Conversion Narratives." Fundamentalisms Comprehended. Ed. Martin E. Marty and R. Scott Appleby. Chicago: U of Chicago P, 1995. 367-96. Print.

Braendlin, Bonnie Hoover. "Bildung in Ethnic Women Writers.” Denver Quarterly 17 (1983): 75-87. Print.

Bromley, David, ed. The Politics of Religious Apostasy: The Role of Apostates in the Transformation of Religious Movements. Westport: Praeger, 1998. Print. 
---, ed. Falling from the Faith: Causes and Consequences of Religious Apostasy. London: Sage, 1988. Print.

Brooks, Joanna. "From Edwards to Baldwin: Heterodoxy, Discontinuity, and New Narratives of American Religious-Literary History.” American Literary History 22.2 (2010): 439-53. Print.

Brown, Dale. "Writing for Joy." Conversations with American Writers: The Doubt, the Faith, the In-Between. Grand Rapids, MI: Eerdmans, 2008. 295-317. Print.

Brown, Fred and Jeanne McDonald. The Serpent Handlers: Three Families and Their Faith. Winston-Salem, NC: John F. Blair, 2000. Print.

Brown, Wendy. "Neo-liberalism and the End of Liberal Democracy." Theory \& Event 7.1 (2003): n. pag. Web. 28 Jan. 2014.

Buckley, Jerome. Season of Youth: The Bildungsroman from Dickens to Golding. Cambridge: Harvard UP, 1974. Print.

Burgess, Stanley M., ed. New International Dictionary of Pentecostal and Charismatic Movements. Grand Rapids, MI: Zondervan, 2002. Print.

Burity, Joanildo. "Entrepreneurial Spirituality and Ecumenical Alterglobalism: Two Religious Responses to Global Neoliberalism." Religion in the Neoliberal Age: Political Economy and Modes of Governance. Ed. Tuomas Martikainen and François Gauthier. New York: Ashgate, 2013. Print.

Burton, Thomas. Serpent-Handling Believers. Knoxville: U of Tennessee P, 1993. Print.

Buss, Helen M. Repossessing the World: Reading Memoirs by Contemporary Women. Waterloo: Wilfrid Laurier UP, 2002. Print. 
Caldwell, Patricia. The Puritan Conversion Narrative: The Beginnings of American Expression. Cambridge: Cambridge UP, 1983. Print.

Caputo, John D. On Religion. New York: Routledge, 2001. Print.

---. The Weakness of God: A Theology of the Event. Bloomington: Indiana UP, 2006. Print.

Carrigan, Henry. "For Every Faith a Holy Writ.” Publishers Weekly 242.41 (1995): 36. Print.

---. "Reinventing American Religion.” Publishers Weekly Religion Update March 1995: S4-S9. Print.

Carrette, Jeremy and Richard King. Selling Spirituality: The Silent Takeover of Religion. New York: Routledge, 2005. Print.

Carroll, Jerry. "The Education of a Novelist." SFGate. San Francisco Chronicle, 30 Sept. 1997. Web. 1 Jan 2015.

Chandler, Siobhan. "Private Religion in the Public Sphere: Life Spirituality in Civil Society." Religions of Modernity: Relocating the Sacred to the Self and the Digital. Eds. Stef Aupers and Dick Houtman. Boston: Brill, 2010. Print.

Charters, Mallay. "Sheri Reynolds: Rebirth of a Novelist." Publishers Weekly 244.39 1997: 54-55. Print.

Clark, Lynn Schofield. "Religion, American Style: Critical Cultural Analyses of Religion, Media, and Popular Culture.” American Quarterly 58.2 (2006): 523-33. Print.

Clemetson, Lynette. "Oprah at the Crossroads.” Newsweek 8 Jan. 2001: 44. Print. 
Coffman, Elesha J. The Christian Century and the Rise of the Protestant Mainline. New York: Oxford UP, 2013. Print.

Cohen, Stefanie. “Katy-clysmic!” New York Post 15 Aug. 2010: 36. Print.

Cohen, Stephen and Arnold Eisen. The Jew Within: Self, Family, and Community in America. Bloomington: Indiana UP, 2000. Print.

Collins, Sheila. "Theology in the Politics of Appalachian Women." Womanspirit Rising: A Feminist Reader in Religion. Ed. Carol Christ and Judith Plaskow. New York: HarperOne, 1992. 149-58. Print.

Cook, Linda Byrd. Dancing in the Flames: Spiritual Journey in the Novels of Lee Smith. Jefferson, NC: McFarland, 2009. Print.

---. “A Spiritual Journey: An Interview with Lee Smith.” Southern Quarterly 47.1 (2009): 74-103. Print.

Covington, Dennis. "Grits and Magic." Washington Post 28 May 1995: X01. Print.

---. Salvation on Sand Mountain: Snake Handling and Redemption in Southern Appalachia. New York: Penguin, 1995. Print.

Crane, Hillary. "Flirting with Conversion: Negotiating Researcher Non-Belief with Missionaries." Crane and Weibel 11-24.

Crane, Hillary and Deana Weibel. Missionary Impositions: Conversion, resistance, and Other Challenges to Objectivity in Religious Ethnography. Plymouth: Lexington, 2013. Print.

Cunningham, Rodger. “Appalachianism and Orientalism: Reflections on Reading Edward Said." Journal of the Appalachian Studies Association 1 (1989): 125-35. Print. 
--- "Writing on the Cusp: Double Alterity and Minority Discourse in Appalachia." The Future of Southern Letters. Ed. Jefferson Humphries and John Lowe. New York: Oxford U P, 1996. 41-53. Print.

Demerath, N. J. "Cultural Victory and Organizational Defeat in the Paradoxial Decline of Liberal Protestantism.” Journal for the Scientific Study of Religion 34.4 (1995): 458-69. Print.

De Vries, Hent. Introduction. Political Theologies: Public Religions in a Post-Secular World. Ed. Hent De Vries and Lawrence E. Sullivan. New York: Fordham UP, 2006. Print.

DeWalt, Kathleen and Billie DeWalt. Participant Observation: A Guide for Fieldworkers. Lanham, MD: AltaMira, 2011. Print.

DiCarlo, Lisa. 'I'm Just a Soul Whose Intentions are Good: Observations from the Back Pew." Crane and Weibel 75-82.

Dilts, Andrew. "From 'Entrepreneur of the Self' to 'Care of the Self': Neoliberal Governmentality and Foucault's Ethics.” Foucault Studies 12 (2011): 130-46. Print.

Douglas, Christopher. "Christian Multiculturalism and Unlearned History in Marilynne Robinson's Gilead." Novel: A Forum on Fiction 44.3 (2011): 333-53. Print. Doyle, Jacqueline. “'These Dark Woods Yet Again’: Rewriting Redemption in Lee Smith's Saving Grace." Critique 41.3 (2000): 273-89. Print.

Dyer, Richard. Heavenly Bodies: Film Stars and Society. London: Routledge, 2004. Print.

---. Stars. London: British Film Institute. 1979. Print. 
Eckard, Paula Gallant. Maternal Body and Voice in Toni Morrison, Bobbie Ann Mason, and Lee Smith. Columbia: U of Missouri P, 2002. Print.

---. "The Prismatic Past in Oral History and Mama Day.” MELUS 20.3 (1995): 121-35. Print.

Emery, Debbie. "Crazy Like a Fox? Megan Fox Reveals She Spoke in Tongues Growing Up.” Radar Online. Radar Online, 15 Jan. 2013. Web. 20 Jan. 2013.

Erzen, Tanya. "Testimonial Politics: The Christian Right's Faith-Based Approach to Marriage and Imprisonment." American Quarterly 59.3 (2007): 991-1015. Print.

Evans, Adrienne and Sarah Riley. "Immaculate Consumption: Negotiating the Sex Symbol in Postfeminist Celebrity Culture." Journal of Gender Studies 22.3 (2013): 268-81. Print.

Falsani, Cathleen. "Barack Obama and the God Factor Interview." Sojourners. Soujourners, 02 Feb. 2012. Web. 10 Feb. 2014.

Feher, Michael. "Self-Appreciation; or, The Aspirations of Human Capital." Public Culture 21.1 (2009): 21-41. Print.

Feinberg, Scott. “Megan Fox Interviewed by Scott Feinberg.” Online video clip. YouTube. YouTube, 10 Sept. 2011. Web. 14 Oct. 2013.

Feng, Pin-chia. The Female Bildungsroman by Toni Morrison and Maxine Hong Kingston: A Postmodern Reading. New York: Peter Lang, 1998. Print.

Ferguson, Mary Anne. "The Female Novel of Development and the Myth of the Psyche." Abel, Hirsch, and Langland 228-43.

Fisher, Stephen. Introduction. Fighting Back in Appalachia: Traditions of Resistance and Change. Philadelphia: Temple UP, 1993. 1-16. Print. 
Foucault, Michel. The Birth of Biopolitics: Lectures at the Collège de France, 1978-79. Trans. Graham Burchell. New York: Palgrave Macmillan, 2008. Print.

---. The Hermeneutics of the Subject: Lectures at the Collège de France. Ed. Frédéric Gros. Trans. Graham Burchell. New York: Palgrave Macmillan, 2007. Print. Frost, W. G. "Our Contemporary Ancestors in the Southern Mountains." Atlantic Monthly 83 (1899): 311-19. Print.

Frye, Joanna. Living Stories, Telling Lives: Women and the Novel in Contemporary Experience. Ann Arbor: U of Michigan P, 1985. Print.

Fuderer, Laura Sue. The Female Bildungsroman in English: An Annotated Bibliography of Criticism. New York: MLA of America, 1990. Print.

Garrett, Lynn. "The Power of the Written Word.” Publishers Weekly 245.11 (1998): S3. Print.

Gershon, Ilana. "Neoliberal Agency.” Current Anthropology 52.4 (2011): 537-55. Print. Gill, Rosalind. Gender and the Media. Cambridge: Polity, 2007. Print.

Gilmore, Leigh and Elizabeth Marshall. "Girls in Crisis: Rescue and Transnational Feminist Autobiographical Resistance." Feminist Studies 36.3 (2000): 667-90. Print.

Grigoriadis, Vanessa. “Sex, God \& Katy.” Rolling Stone 19 Aug. 2010: 40-47. Print. Gunderson, Edna. "Perry Lives a 'Teenage Dream.” USA Today 19 Aug. 2010: D1. Print.

Guralnick, Peter. “The Storyteller’s Tale.” Tate 140-52.

Habermas, Jürgen. "Notes on a Postsecular Society." signandsight.com, June 182008. Web. 5 May 2010. 
---. An Awareness of What is Missing: Faith and Reason in a Post-secular Age. Trans.

Ciaran Cronin. Cambridge: Polity Press, 2010. Print.

Hall, Joan Wylie. “Arriving Where She Started: Rewdemption at Scrabble Creek in Lee Smith’s Saving Grace." Pembrooke Magazine 34 (2002): 91-99. Print.

Hall, Stuart. "The Neo-liberal Revolution.” Cultural Studies 25.6 (2011): 705-28. Print.

Halperin, Shirley. "Katy Perry, Superstar." Cosmopolitan Aug. 2009: 28-32. Print.

Harding, Susan. The Book of Jerry Falwell: Fundamentalist Language and Politics. Princeton: Princeton UP, 2000. Print.

Harkins, Anthony. Hillbilly: A Cultural History of an American Icon. New York: Oxford UP, 2004. Print.

Harold, Zack. "Snake Handlers Shy from Outsiders." Charleston Gazette 29 May 2013: 1A. Print.

Hart, D. G. That Old-Time Religion in Modern America: Evangelical Protestantism in the Twentieth Century. Chicago: Ivan R. Dee, 2002. Print.

Hartman, Andrew. "Hollinger on the Protestant Dialectic." Jacobin. Jacobin Mag. 2 Aug. 2011. Web. 2 Feb. 2014.

Harvey, David. A Brief History of Neoliberalism. New York: Oxford UP, 2007. Print. Hazelwood Donlon, Jocelyn. "Hearing Is Believing: Southern Racial Communities and Strategies of Story-Listening in Gloria Naylor and Lee Smith.” Twentieth Century Literature 41.1 (1995): 16-35. Print.

Hedstrom, Matthew. The Rise of Liberal Religion: Book Culture and American Spirituality in the Twentieth Century. New York: Oxford UP, 2012. Print. 
Heilbrun, Carolyn. "Women's Autobiographical Writings: New Forms." Women and Autobiography. Ed Martine Watson Brownley and Allison Kimmich. Washington: Scholarly Resources, 1999. 15-34. Print.

Hempton, David. Evangelical Disenchantment: Nine Portraits of Faith and Doubt. New Haven: Yale UP, 2008. Print.

Hendricks Wallace, Anne. "Ethical Readings of Folklore: Can We Stop Turning the Southern Folk of Lee Smith's Oral History into Commodities?" Southern Studies 4.4 (1993): 361-76. Print.

Hermes, Joke. "Reading Gossip Magazines: The Imagined Communities of 'Gossip' and 'Camp."' The Celebrity Culture Reader. Ed. P. David Marshall. New York: Routledge, 2006. Print.

Heltzel, Peter Goodwin. Jesus and Justice: Evangelicals, Race, and American Politics. New Haven: Yale UP, 2009. Print.

Hill, Dorothy Combs. Lee Smith. New York: Twayne, 1991. Print. Hill, Reinhold L. “'These Stories Are not 'Real,' but They Are as True as I Can Make Them': Lee Smith's Literary Ethnography.” Southern Folklore 57.2 (2000): 10618. Print.

Hilton, Perez. "Katy Perry Reveals Her Parents Speak In Tongues!!!” perezhilton.com. n.p., 2 Aug. 2010. Web. 14 Oct. 2013.

Hirschberg, Lynn. "Stardom Becomes Her.” New York Times Magazine 15 Nov. 2009: 57. Print.

Hochschild, Arlie Russell. The Commercialization of Intimate Life: Notes from Home and Work. Berkeley: U of California P, 2003. Print. 
Hollinger, David. “After Cloven Tongues of Fire: Ecumenical Protestantism and the Modern American Encounter with Diversity." The Journal of American History 98.1 (2011): 21-48. Print.

---. After Cloven Tongues of Fire: Protestant Liberalism in Modern American History. Princeton: Princeton UP, 2013. Print.

Hood, Ralph W. Foreword. The Serpent Handlers: Three Families and Their Faith. By Fred Brown and Jeanne McDonald. Winston-Salem, NC: John F. Blair, 2000. Print.

---. Rev. of Salvation on Sand Mountain, by Dennis Covington. Appalachian Heritage 23.3 (1995): 54-56. Print.

Hood, Ralph W. and W. Paul Williamson. Them That Believe: The Power and Meaning of the Christian Serpent-Handling Tradition. Berkeley: U of California P, 2008. Print.

Hooper, Johnson Jones. Adventures of Captain Simon Suggs. Chapel Hill: U of North Carolina P, 1969. Print.

House, Silas. “A Day with Lee Smith.” Appalachian Heritage 31.1 (2003): 16-23. Print. Hovis, George. "Pentecostals." The Companion to Southern Literature. Ed. Joseph M. Flora and Lucinda H. MacKethan. Baton Rouge: Louisiana State UP, 2002. 62427. Print.

Hungerford, Amy. Postmodern Belief: American Literature and Religion since 1960. Princeton: Princeton UP, 2010. Print.

Illouz, Eva. Cold Intimacies: The Making of Emotional Capitalism. Cambridge: Polity, 2007. Print. 
Inherit the Wind. Dir. Stanley Kramer. Stanley Kramer Productions, 1960. Film.

Jackson, Harvey. "Sand Mountain, Snakes, Being Southern.” Annistonstar.com. Anniston Star, 23 Sept. 2010. Web. 1 Jan. 2015.

Jackson, Peter, Nick Stevenson, and Kate Brooks. Making Sense of Men's Magazines. Cambridge: Polity, 2001. Print.

Jacobs, Alexandra. "Bad Girl Gone Good.” Allure 1 June 2010: 154. Print.

Jane. "Megan Fox Esquire Interview Makes Her Look Like a Sexy Crazy.” Celebrity News and Style. N.p., 17 Jan. 2013. Web. 20. Jan. 2013.

Jesus Camp. Dir. Heidi Ewing and Rachel Grady. Loki Films, 2006. Film.

Johnson, Donna. Holy Ghost Girl: A Memoir. New York: Gotham, 2011. Print.

Jones, Suzanne. "City Folks in Hoot Owl Holler: Narrative Strategy in Lee Smith's Oral History." The Southern Literary Journal 20.1 (1987): 101-12. Print.

Katy Perry: Part of Me. Dir. Dan Cutforth and Jane Lipsitz. Insurge Pictures, 2012. Film.

"Katy Perry: 'Speaking in Tongues is as Normal to me as 'Pass the Salt."," celebitchy.com. Celebitchy, 2 Aug. 2010. Web. 14 Oct. 2013.

Katz, David. “Good Morning Megan.” Esquire June 2009: 98-107. Print.

Kaufmann, Michael W. "Locating the Postsecular." Religion \& Literature 41.3 (2009): 68-73. Print.

---. "Post-secular Puritans: Recent Retrials of Anne Hutchinson." Early American Literature 45.1 (2010): 31-59. Print.

---. "The Religious, the Secular, and Literary Studies: Rethinking the Secularization Narrative in Histories of the Profession." New Literary History 38.4 (2007): 60728. Print. 
Kawulich, Barbara. "Participant Observation as a Data Collection Method." FQS 6.2 (2005): n. pag. Web. 26 Nov. 2014.

Kay, William. Pentecostalism: A Very Short Introduction. New York: Oxford UP, 2011. Print.

Kellstedt, Lyman, and Corwin Smidt. "Measuring Fundamentalism: An Analysis of Different Operational Strategies." Religion and the Culture Wars: Dispatches from the Front. Ed. John Green et al. Lanham: Rowman \& Littlefield, 1996. 193218. Print.

Kerney, Kelly. Born Again. Orlando: Harcourt, 2006. Print.

Kimbrough, David. Taking Up Serpents: Snake Handlers of Eastern Kentucky. Chapel Hill: U of North Carolina P, 1995. Print.

Kiefer, Halle. “'What Distracts Me From My Reality Is Bigfoot': Megan Fox's 8 Weirdest New Esquire Quotes.” vh1.com. Viacom, 15 Jan. 2013. Web. 22 Oct. 2013.

Larson, Edward. Summer of the Gods: The Scopes Trial and America's Continuing Debate over Science and Religion. New York: Basic Books, 1997. Print.

Lau, Kimberly. New Age Capitalism: Making Money East of Eden. Philadelphia: U of Pennsylvania P, 2000. Print.

Lawless, Elaine J. “'The Night I Got the Holy Ghost...': Holy Ghost Narratives and the Pentecostal Conversion Process.” Western Folklore 47:1 (1988): 1-19. Print.

Lemke, Thomas. "'The Birth of Bio-politics': Michel Foucault's Lecture at the Collège de France on Neo-liberal Governmentality.” Economy and Society 30.2 (2001): 190-207. Print. 
Levitt, Laura. "What is Religion, Anyway? Rereading the Postsecular from an American Jewish Perspective.” Religion \& Literature 41.3 (2009.): 107-18. Print.

Lewis, Andrew R. and Dana Huyser de Bernardo. "Belonging Without Belonging: Utilizing Evangelical Self-Identification to Analyze Political Attitudes and Preferences.” Journal for the Scientific Study of Religion 49.1 (2010): 112-26. Print.

Lewis, Helen, Linda Johnson, and Donald Askins, eds. Colonialism in Modern America: The Appalachian Case. Boone, NC: Appalachian Consortium, 1978. Print.

Lewis, Sinclair. Elmer Gantry. New York: Dell, 1954. Print.

Liebman, Joshua Loth. Peace of Mind. New York: Simon and Schuster, 1946. Print.

Lindsay, D. Michael. "Ties That Bind and Divisions That Persist: Evangelical Faith and the Political Spectrum.” American Quarterly 59.3 (2007): 883-909. Print.

Livingston, Billie. Cease to Blush. Toronto: Vintage, 2006. Print.

Lofton, Kathryn. Oprah: The Gospel of an Icon. Berkeley: U of California P, 2001. Print. Luckmann, Thomas. "The Structural Conditions of Religious Consciousness in Modern Societies.” Japanese Journal of Religious Studies 6.1-2 (1979): 121-37. Print. Ludwig, Kathryn. “Don DeLillo's Underworld and the Postsecular in Contemporary Fiction.” Religion \& Literature 41.3 (2009): 82-91. Print. Lyon Julie. Holy Roller. Colorado Spring: WaterBrook, 2009. Print. Maasen, Sabine. "Governing by Will: The Shaping of the Will in Self-Help Manuals." Psychology's Territories: Historical and Contemporary Perspectives from Different Disciplines. Ed. Mitchell Ash and Thomas Sturm. Mahwah, NJ: Lawrence Erlbaum, 2007. 111-28. Print. 
Maczynska, Magdalena. “Toward a Postsecular Literary Criticism: Examining Ritual Gestures in Zadie Smith's Autograph Man." Religion \& Literature 41.3 (2009): 73-82. Print.

Madsen, Ole Jacob. The Therapeutic Turn: How Psychology Altered Western Culture. New York: Routledge, 2014. Print.

Marche, Stephen. "Megan Fox Saves Herself." Esquire Feb. 2013: 60-66. Print.

Marshall, P. David. Celebrity and Power: Fame in Contemporary Culture. Minneapolis: U of Minnesota P, 2014. Print.

---. "The Promotion and Presentation of the Self: Celebrity as Marker of Presentational Media." Celebrity Studies 1.1 (2010): 35-48. Print.

Max, D. T. “The Oprah Effect.” New York Times 26 Dec. 1999: SM36. Print.

McLaurin, Tim. “A Simple Faith, Deftly Handled.” Washington Post 16 Mar. 1995: D2. Print.

McClure, John. "Postmodern/Post-Secular: Contemporary Fiction and Spirituality." Modern Fiction Studies 41.1 (1995): 141-63. Print.

---. Partial Faiths: Postsecular Fiction in the Age of Pynchon and Morrison. Athens, GA: U of Georgia P, 2007. Print.

McDermott, Monika L. "Religious Stereotyping and Voter Support for Evangelical Candidates." Political Research Quarterly 62.2 (2009): 340-54. Print.

McGee, Micki. Self Help, Inc.: Makeover Culture in American Life. New York: Oxford U P, 2005. Print.

Meigs, Anna. "Ritual Language in Everyday Life: The Christian Right." Journal of the American Academy of Religion 63.1 (1995): 85-103. Print. 
"Megan Fox May be Hot, But She is Also Really Crazy." CBSDetroit. CBS, 16 Jan. 2013. Web. 20 Jan. 2013.

"Megan Fox Speaks In Tongues and Is Symmetrical: An Analysis of Esquire's Terrible Profile." Gawker. Gawker Media Group, 16 Jan. 2013. Web. 21 Oct. 2013. Mencken, H. L. The Impossible H.L. Mencken: A Selection of His Best Newspaper Stories. Ed. Marion Elizabeth Rodgers. New York: Doubleday, 1991. Print. Merriam, Sharan. Qualitative Research: A Guide to Design and Implementation. San Francisco: Jossey-Bass, 2009. Print.

Merrick, Elizabeth. Girly. New York: Demimonde, 2006. Print.

Milbank, John, Catherine Pickstock, Graham Ward, eds. Radical Orthodoxy: A New Theology. London: Routledge, 1999. Print.

Milbank, John and Simon Oliver, eds. The Radical Orthodoxy Reader. London: Routledge, 2009. Print.

Moran, Joe. Star Authors: Literary Celebrity in America. London: Pluto, 2000. Print. Morgan, Ellen. "Humanbecoming: Form and Focus in the Neo-Feminist Novel." Images of Women in Fiction: Feminist Perspectives. Ed. Susan Koppelman Cornillon. Bowling Green: Bowling Green U P, 1971. 183-205. Print.

Myers, Andrew. “The Fantastic Ms. Fox.” Miami. Modern Luxury, 22 Feb. 2012. Web 14 Oct. 2013.

Nelson, Marcia. “Gimme That Old-Time Spirituality.” Publishers Weekly 251.12 (2004): S2-S8. Print.

---. “Losing Their Religion.” Publishers Weekly 260.3 (2013): 16-17. Print.

Nixon, Will. “The Flight from 'New Age.”' Publishers Weekly 237.49 (1990): 21. Print. 
Nunn, Anna and Anita Biressi. “'A Trust Betrayed”: Celebrity and the Work of Emotion." Celebrity Studies 1.1 (2010): 49-64. Print.

Obama, Barack. "Building a Covenant for a New America." Sojourners. Soujourners, 21 Feb. 2012. Web. 10 Feb. 2014.

Ommundsen, Wenche. "From the Altar to the Market-Place and Back Again: Understanding Literary Celebrity." Stardom and Celebrity: A Reader. Ed. Sean Redmond and Su Holmes. Los Angeles: Sage, 2007. 244-56. Print.

"Oprah Shuts the Book." Times-Picayune 8 Apr. 2002: M1. Print.

Orsi, Robert. Between Heaven and Earth: The Religious Worlds People Make and the Scholars who Study Them. Princeton: Princeton U P, 2005. Print.

Ostwalt, Conrad. "Witches and Jesus: Lee Smith's Appalachian Religion." The Southern Literary Journal 31.1 (1998): 98-118. Print.

Packer, Z. Z. "Speaking in Tongues.” Drinking Coffee Elsewhere. New York: Riverhead, 2003. 133-88. Print.

Palmer, Susan J. "Caught Up in the Cult Wars: Confessions of a Canadian Researcher." Misunderstanding Cults: Searching for Objectivity in a Controversial Field. Ed. Benjamin Zablocki and Thomas Robbins. Toronto: U of Toronto P, 2001. 99-122. Print.

Paris, Arthur E. Black Pentecostalism: Southern Religion in an Urban World. Amherst: U of Massachusetts P, 1982. Print.

Parks, Tim. Tongues of Flame. New York: Grove, 1985. Print.

Parrish, Nancy. “"Ghostland': Tourism in Lee Smith's Oral History.” The Southern Quarterly 32.2 (1994): 37-47. Print. 
Pearson, Stephen. “'The Last Bastion of Colonialism': Appalachian Settler Colonialism and Self-Indigenization.” American Indian Culture and Research Journal 37.2 (2013): 165-84. Print.

Peck, Jamie. Constructions of Neoliberal Reason. New York: Oxford UP, 2010. Print. Peck, Janice. The Age of Oprah: Cultural Icon for the Neoliberal Era. Boulder: Paradigm, 2008. Print.

Penn, Denise and Lance Perkins. "Katy Perry does Dinah.” Lesbian News Apr. 2009: 2830. Print.

Perry, Kevin. “I'm a Filthy MILF and I Love It." Loaded Oct. 2014: 32-39. Print.

Poewe, Karla. "Charismatic Conversion in Light of Augustine's Confessions." Religious Conversion: Contemporary Practices and Controversies. Ed. Christopher Lamb and M. Darrol Bryant. New York: Cassell, 1999. 191-206. Print.

Poland, L. M. "Augustine, Allegory, and Conversion.” Journal of Literature and Theology 1 (1988): 37-48. Print.

Pond, Lauren. "Witnessing a Faith and its Price." Washington Post 1 June 2012: C01. Print.

Rak, Julie. Boom! Manufacturing Memoir for the Popular Market. Waterloo: Wilfrid Laurier UP, 2013. Print.

Reynolds, Sheri. “Book Notes.” sherireynolds.com. N.p., n.d. Web. 1 Jan. 2015.

---. The Rapture of Canaan. New York: Berkley, 1997. Print.

Richard, Mark. House of Prayer No. 2: A Writer's Journey Home. New York: Anchor, 2011. Print. 
Rishoi, Christy. From Girl to Woman: American Women's Coming-of-Age Narratives. New York: State U of New York P, 2003. Print.

Robinson, Lisa. “Katy Perry's Grand Tour.” Vanity Fair 1 June 2011: 160. Print.

Rojek, Chris. Fame Attack: The Inflation of Celebrity and Its Consequences. London: Bloomsbury Academic, 2012. Print.

Rooney, Kathleen. Reading with Oprah: The Book Club that Changed America. Fayetteville: U of Arkansas P, 2005. Print.

Rose, Ellen Cronan. "Through the Looking Glass: When Women Tell Fairy Tales.” Abel, Hirsch, and Langland 209-27.

Rose, Nikolas. Inventing our selves: Psychology, Power, and Personhood. Cambridge: Cambridge UP, 1996. Print.

---. Governing the Soul: The Shaping of the Private Self. London: Routledge, 1990. Print. Rosen, Christine. My Fundamentalist Education: A Memoir of a Divine Girlhood. New York: PublicAffairs, 2005. Print.

Ryan, Maureen. Innocence and Estrangement in the Fiction of Jean Stafford. Baton Rouge: Louisiana UP, 1987. Print.

Satterwhite, Emily. Dear Appalachia: Readers, Identity, and Popular Fiction Since 1878. Lexington: U of Kentucky P, 2012. Print.

Scaggs, Austin. “Q\&A: Katy Perry.” Rolling Stone 21 Aug. 2008: 30. Print.

Schmeling, Sharon. “Author Enters World of Snake Handling.” St. Louis Post-Dispatch 23 Apr. 1995: 5C. Print.

Schmidt, Leigh Eric. Restless Souls: The Making of American Spirituality. New York: Harper Collins, 2005. Print. 
Schlumpf, Heidi. "Religion vs. Spirituality." Publishers Weekly 246.35 (1999): S4-S9. Print.

Schuessler, Jennifer. “A Religious Legacy, With Its Leftward Tilt, is Reconsidered." New York Times 23 July 2013: C1. Print.

Scott, Shaunna. “'They Don't Have to Live by the Old Traditions': Saintly Men, Sinner Women, and an Appalachian Pentecostal Revival." American Ethnologist 21.2 (1994): 227-44. Print.

Sherrill, John. They Speak with Other Tongues. Old Tappan, NJ: Spire, 1965. Print.

Shoup, Barbara and Margaret-Love Denman. Novel Ideas: Contemporary Authors Share the Creative Process. Athens, GA: U of Georgia P, 2009. Print.

Siegel, Kristi. Women's Autobiographies, Culture, Feminism. New York: Peter Lang, 1999. Print.

Silva, Jennifer. Coming Up Short: Working-Class Adulthood in an Age of Uncertainty. New York: Oxford UP, 2013. Print.

Singleton, Andrew. "The Importance of Narrative in Negotiating Otherworldly Experiences: the Case of Speaking in Tongues." Narrative Inquiry 12.2 (2002): 351-73. Print.

Smith, Anthony Paul and Daniel Whistler. Introduction. After the Postsecular and the Postmodern: New Essays in Continental Philosophy of Religion. Ed. Anthony Paul Smith and Daniel Whistler. Newcastle upon Tyne: Cambridge Scholars, 2010. Print.

Smith, Christian. Christian America: What Evangelicals Really Want. Berkley: U of California P, 2000. Print. 
Smith, John E. "The Concept of Conversion." Conversion: Perspectives on Personal and Social Transformation. Ed. Walter E. Conn. New York: Alba, 1978. 51-60. Print. Smith, Lee. Interview by Charline McCord. The Mississippi Quarterly 52.1 (1998): 89. Print.

---. Interview by Susan Ketchin. The Christ-Haunted Landscape: Faith and Doubt in Southern Fiction. Ed. Susan Ketchin. Jackson: U of Mississippi P, 1994. 44-55. Print.

---. Interview by Susan Ketchin. Saving Grace: Reader's Circle Edition. New York: Ballantine, 2003. 279-86. Print.

---. Oral History. New York: G. P. Putnam's, 1983. Print.

---. Saving Grace. New York: Ballantine, 1995. Print.

---. "Tongues of Fires." The Christ-Haunted Landscape: Faith and Doubt in Southern Fiction. Ed. Susan Ketchin. Jackson: U of Mississippi P, 1994. 5-43. Print.

Smith, Rebecca. Gender Dynamics in the Fiction of Lee Smith: Examining Language and Narrative Strategies. San Francisco: International Scholars, 1997. Print.

Smith, Sidonie. A Poetics of Women's Autobiography: Marginality and the Fictions of Self-Representation. Bloomington: Indiana U P, 1987. Print.

Smith, Sidonie and Julia Watson. Reading Autobiography: A Guide for Interpreting Life Narratives. Minneapolis: U of Minnesota P, 2001. Print.

Soos, Frank. "Insiders and Outsiders: Point of View in Lee Smith's Oral History." The Iron Mountain Review 3.1 (1986): 20-24. Print.

Spalding, John D. "Stirring the Waters of Reflection.” Publishers Weekly 244.31 (1997): 73-80. Print. 
Spengemann, William. Forms of Autobiography: Episodes in the History of a Literary Genre. New Haven: Yale UP, 1980. Print.

Spoon, Rae. First Spring Grass Fire. Vancouver: Arsenal Pulp, 2012. Print.

Standora, Leo. "Speaking in Tongues with Sexy Katy Perry." New York Daily News 1 Aug. 2010: 10. Print.

Stevick, Daniel. Beyond Fundamentalism. Richmond: John Knox, 1964. Print.

Streib, Heinz. "Deconversion." Oxford Handbook on Religious Conversion. Ed. L. R. Rambo and C. E. Farhadian. Oxford: Oxford UP, 2014. 271-96. Print.

Streib, Heinz and Barbara Keller. "The Variety of Deconversion Experiences: Contours of a Concept in Respect to Empirical Research.” Archive for the Psychology of Religion 26 (2004): 181-200. Print.

Strombeck, Andrew. "Invest in Jesus: Neoliberalism and the Left Behind Novels." Cultural Critique 64 (2006): 161-95. Print.

Syba, Michelle. "At the Judgement Seat.” killingthebuddha.com. Killing the Buddha, 3 Sept. 2013. Web. 21 Mar. 2013.

---. "Pentecost in Mexico." killingthebuddha.com. Killing the Buddha, 27 May 2013. Web. 21 Mar. 2013.

Tate, Linda, ed. Conversations with Lee Smith. Jackson: UP of Mississippi, 2001. Print. Taylor, Charles. A Secular Age. Cambridge: Belknap, 2007. Print.

Taylor, Mark C. Erring: A Postmodern A/Theology. Chicago: U of Chicago P, 1984. Print. 
Tincknell, Estella, Deborah Chambers, Joost Van Loon, and Nichola Hudson. "Begging for It: 'New Femininities,' Social Agency, and Moral Discourse in Contemporary Teenage and Men's Magazines.” Feminist Media Studies 3.1 (2003): 47-63. Print.

Turner, Graeme. “Approaching Celebrity Studies.” Celebrity Studies 1.1 (2010): 11-20. Print.

---. Understanding Celebrity. Thousand Oaks: Sage, 2013. Print.

Twain, Mark. Adventures of Huckleberry Finn. Berkeley: U of California P, 1985.

Ventura, Patricia. Neoliberal Culture: Living with American Neoliberalism. Farnham: Ashgate, 2012. Print.

Vernon, Alex. Soldiers Once and Still: Ernest Hemingway, James Salter, and Tim O'Brien. Chicago: U of Iowa P, 2007. Print.

Verter, Bradford. "Spiritual Capital: Theorizing Religion with Bourdieu Against Bourdieu." Sociological Theory 21.2 (2003): 150-174. Print.

Wagner, Erica. "Margaret Atwood: The Conversation.” Times 15 Aug. 2009. Web. 5 Jan. 2014.

Wallace, Amy. "Love, Sex, and Madness.” GQ Feb. 2014: 66-70+. Print.

Wallis, Jim. God's Politics: Why the Right Gets It Wrong and the Left Doesn't Get It. New York: HarperCollins, 2005. Print.

Walzer, Philip. “Life After Oprah.” Virginian Pilot 23 Apr. 2006: E1. Print.

Watkins, Owen C. The Puritan Experience: Studies in Spiritual Autobiography. London: Routledge, 1972. Print.

Watt, David Harrington. “Losing Our Religion.” Religion \& Literature 41.3 (2009): 11926. Print. 
Weaver, John. Evangelicals and the Arts in Fiction: Portrayals of tension in NonEvangelical Works Since 1895. Jefferson: McFarland, 2013. Print.

Weaver-Spurr, Kim. "Snake-handling Leads to Self-discovery." Herald-Sun 3 Feb. 1995: 3. Print.

Weintraub, Karl. "Autobiography and Historical Consciousness.” Critical Inquiry 1.4 (1975): 821-48. Print.

Weller, Jack. Yesterday's People: Life in Contemporary Appalachia. Lexington: U of Kentucky P, 1965. Print.

Wernick, Andrew. Promotional Culture: Advertising, Ideology, and Symbolic Expression. London: Sage, 1991. Print.

Werthheimer, Jack. A People Divided: Judaism in Contemporary America. New York: HarperCollins, 1993. Print.

---. “Judaism a la Carte.” Moment 19.4 (1994): 54-55+. Print.

Whisnant, David. Modernizing the Mountaineer: People, Power, and Planning in Appalachia. Knoxville: U of Tennessee P, 1994. Print.

Wiegele, Katharine. "On Being a Participant and an Observer in Religious Ethnography: Silence, Betrayal, and Becoming." Crane and Weibel 83-92.

Willey, Robin D. "Becoming Data: Star Trek Wisdom and the Unforseen Effects of Fieldwork on the Fieldworker." Journal of Religion and Popular Culture 22.3 (2010): n. pag. Web. 13 Sept. 2011.

Williams, Daniel K. God's Own Party: The Making of the Christian Right. New York: Oxford UP, 2010. Print. 
Wilson, Diane. Holy Roller: Growing Up in the Church pf Knock Down Drag Out; or, How I Quit Loving a Blue-Eyed Jesus. White River Junction: Chelsea Green, 2008. Print.

Winston, Kimberley. "Literary Lions to Roar About Religion.” Publishers Weekly 247.34 (2000): S11-S13. Print.

Winterson, Jeanette. Oranges Are Not the Only Fruit. London: Vintage, 2010. Print.

---. Why Be Happy When You Could Be Normal? New York: Grove, 2011. Print.

Wolf, Jeanne. “Megan Fox: 'My Sense of Humor Doesn't Translate.'” parade.com.

Parade Magazine, 15 Sept. 2009. Web. 13 Nov. 2013.

Wood, Matthew. Possession, Power, and the New Age. Farnham: Ashgate, 2007. Print.

Woodberry, Robert D. and Christian Smith. "Fundamentalism Et Al: Conservative Protestants in America." Annual Review of Sociology 24 (1998): 25-56.

York, Lorraine. Margaret Atwood and the Labour of Literary Celebrity. Toronto: $\mathrm{U}$ of Toronto P, 2013. Print. 